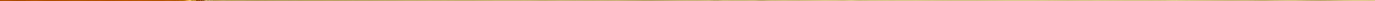


$B A, \quad \frac{80}{\circ}$

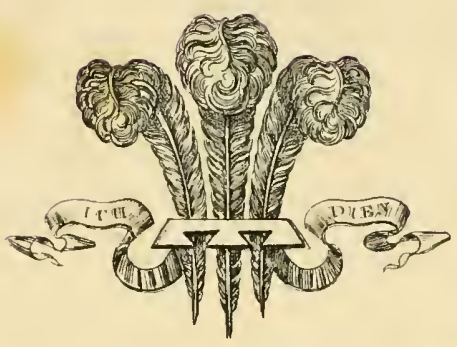

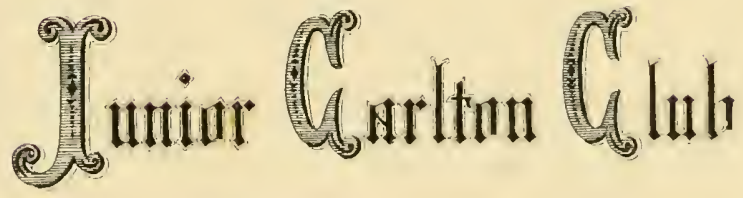

LUBRAY
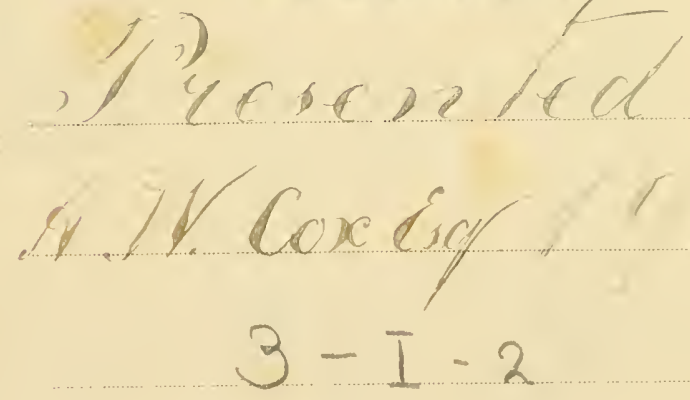

EXTRACT FROM THE RULES.

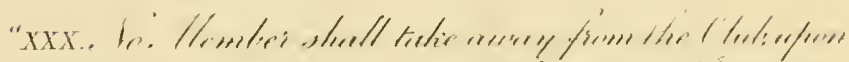

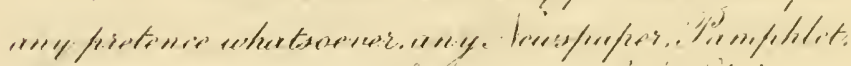

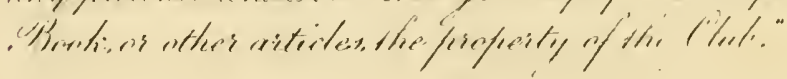




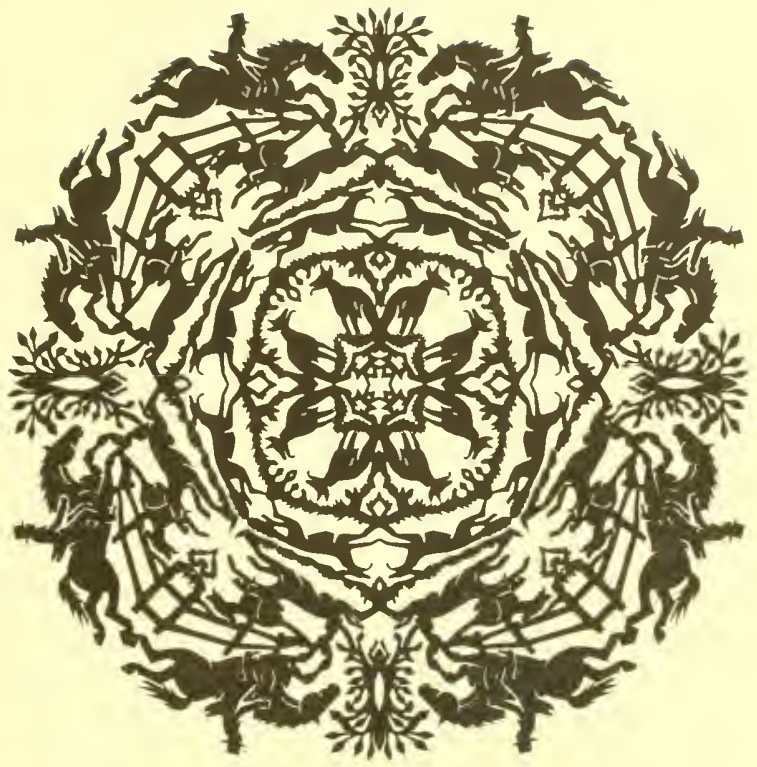

JOHN A.SEAVERNS 



\section{GA L ICIA}

\section{HER FORBEARS AND HER OFFSPRING}






$$
\frac{10}{4}
$$




\title{
GA LICIA
}

\section{HER FORBEARS AND HER OFFSPRING}

\author{
BY \\ ALFRED E. T. WATSON \\ ASSISTANT EDITOR OF "THE BADMINTON LIBRARY," SECTIONAL EDITOR OF THE \\ "ENCYCLOP,EDIA BRITANNICA," EDITOR "BADMINTON MAGAZINE," AUTHOR OF \\ "KING EDWARD VII AS A SPORTSMAN," "SKETCHES IN THE HUNTING \\ FIELD," " RACECOURSE AND COVERTSIDE," "THE RACING WORLD \\ AND ITS INHABITANTS," "THE TURF," "RACING AND \\ 'CHASING," "LORD DERBV'S RACEHORSES" (printed \\ for priz'ate circulation), ETC.
}

WITH 30 ILLUSTRATIONS

PRIVATELY PRINTED FOR MR. A. W. COX ("MR. FAIRIE")

\section{LONGMANS, GREN AND CO.}

39 PATERNOSTER ROW, LONDON FOURTH AVENUE \& 30TH STREET, NEW YORK BOMBAY, CALCUTTA, AND MADRAS

I 9 I 5

All rights reserved 



\section{CONTENTS}

CHAI.

P'AGE

I. GALICIA AND HER PARENTAGE . . . I

II. BAY RONALD • . . . . . . 33

III. BAYARDO • . . . . . . . 7 I

IV. LEMBERG •

V. SILESIA, ZIA, AND RADAMES. • . . 157

VI. BAYARDO AT THE STUD . . . . I I I

The Pedigree of Bayardo . . . . . 177

The Pedigree of Lemberg . . . . . 178 



\section{LIST OF ILLUSTRATIONS}

Photographs by W. A. Rouch and Clarence Hailey

\section{PHOTOGRAVURE PLATES}

Galicia . . . . . . . . . Frontispiece

From a Painting in the possession of her Owner.

BAYARDO . . . . . . . To facepage $7 \mathbf{I}$

From the Painting by A. C. Havell.

Bayardo with His TRAINER, Alec TAYlor

(D. MAHER UP) • • • • . . " " IOI

CYllene. . . . . . . . . . . . . .

LEMBERG LED IN AFTER WINNING THE DERBY,

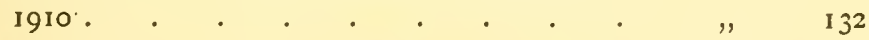

LEMBERG JUST AFTER WINNING THE DERBY,

IgIO . . . . . . . . . . . .

FACSIMILE OF NOTE BY OWNER ON NAMIING OF

BAYARDO . . . . . Between pages II8 \& II9

\section{HALF-TONE PLATES}

Galopin, Sire of Galicia. . . . . To face page 2

SPEEDWELl PADDOCKS, NeWMaRKeT . . " 12

Green Lodge, NewMarket (MR. J. RYAN IN FRONT), WHERE GALICIA WAS TRAINED WHEN SHE WON HER FIRST RACE AT ASCOT "

The Manton Stables . . . . . . $\quad$ " 27

BAY RONALD . . . . . . . . . " 433

vii 


\section{LIST OF ILLUSTRATIONS}

"Mr. FAIRIE'S" House on The Severals at

NewMaRKET . . . . . . . To face page

BAYARDO AS A THREE-YEAR-OLD . . . " " 8 I

BAYARDO WINNING THE ECLIPSE STAKES FROM Royal Realm, Santo Strato, and Your

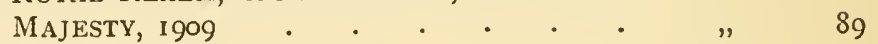

THE ST. LEgER FIELD, IgO9. BAYARDo ON

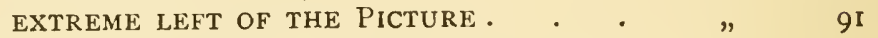

BAYARDO JUMPING OFF AT THE START FOR THE ST. LEGER, IgO9 • . . . . .

BAYARDO WINNING THE ST. LEGER FROM VALENS AND MIRADOR, IgO9 • . . " 69 I

BAYARDO GETS RID OF HIS JOCKEY AT THE START FOR THE ASCOT GOLD CUP, 1910 .

BAYARDO LEADING THE FIELD FOR THE ASCOT Gold CUP AT THE BOTTOM TURN, IgIo .

ON THE MANTON DOWNS . . . . " 106

LEMBERG AS A TWO-YEAR-OLD . . . . " " 122

LEMBERG WHILST IN TRAINING . • . . " " 128

LEMBERG WINNING THE DERBY FROM GREENBaCk AND Charles O'MALley, I9IO . . " " 130

LEMBERG'S TOILET AT SHERWOOD'S COTTAGE AFTER THE DERBY, IgIO . . . . " " I

LEMBERG, ON THE RIGHT, JUMPING OFF FOR the St. James's Palace Stakes, Ascot, I9IO .

LEMBERG AND NEIL GOW DEAD-HEATING FOR THE EClipse Stakes at Sandown PaRk,

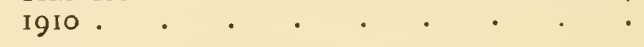

LeMBERg at THE StUd . . . •

"MR. FAIRIE'S" PADDOCKS AT NEWMARKET "

THE LATEST PORTRAit OF Galicia, TAKEN WHILE ON A VISIT TO CICERO, APRIL I9I5. BAYARdo at THE MANTON STUd viii . . 


\section{GA L I G IA}

\section{HER FORBEARS AND HER OFFSPRING}

\section{CHAPTER I}

\section{GALICIA AND HER PARENTAGE}

THE reputation of a horse quickly fades. Ideas exist as to which were absolutely the best ever known, it being generally assumed that the question is between St. Simon and Ormonde, two who were never beaten-and it is exceedingly rare for any horse to escape at least one defeat-though admirers of other animals hold exalted opinions of them. But the great horse who has stood out from his contemporaries is soon forgotten, nor can accurate details concerning him, the achievements on which his fame rests, be easily found. They are hidden away in the files of old sporting papers, of other papers, indeed, for at any rate of late years there have been few journals which have not devoted considerable space to racing. But these publications are not readily accessible. Articles in a magazine now and then, or a 


\section{GALICIA : HER FORBEARS}

chapter in a casual book which deals with the sport, would also supply particulars more or less authoritative if it were known where such information was to be discovered. But it is only in extremely rare cases that justice is done to the memory of the horses on whom the character and ascendency of the British thoroughbred mainly rest.

It is for this reason that I have undertaken to write an account of Galicia, her Forbears and her Offspring; for she herself sprang from the most aristocratic of parents, and her children include, besides a Derby winner, one who, notwithstanding that he missed that unique distinction, was beyond doubt the best horse in the Derby of his year; for I am of course speaking of Bayardo, who subsequently showed with the most unmistakable distinctness what ought to have happened at Epsom, where the result of the classic was affected by an accident, to be described in its proper place.

Before dealing with Galicia herself something must be said about her parents. In the year I $897 \mathrm{Mr}$. A. W. Cox, known in racing history as "Mr. Fairie," owned a mare named Isoletta, a daughter of Isonomy, and sent her to Galopin, then standing at the Blankney Stud Farm, and rated as the leading sire of his period. Nine of 


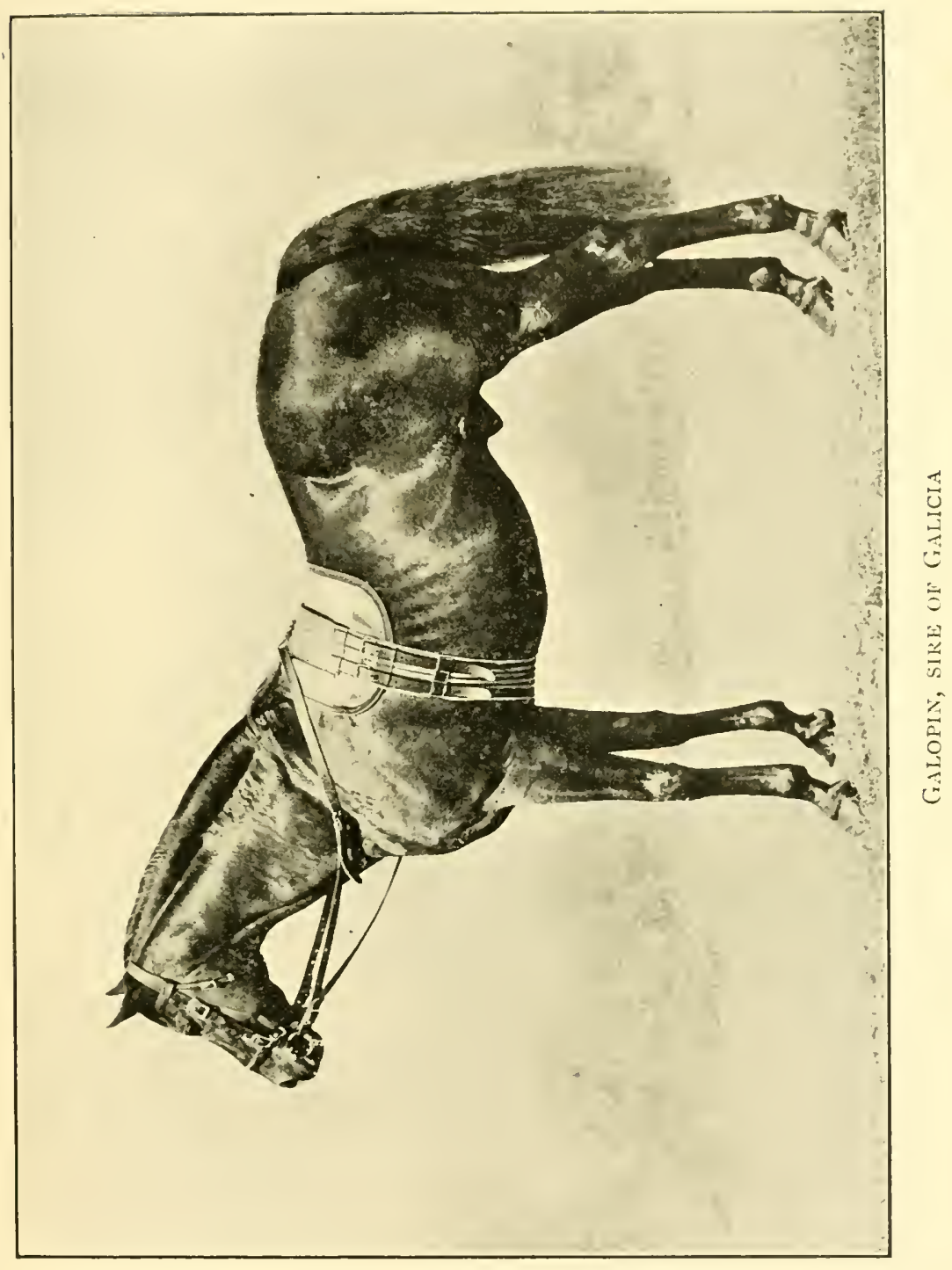





\section{AND HER OFFSPRING}

his yearlings had been sold the previous year for an average of II54 guineas. It is not certain that there was ever a much better horsepossibly in this connection the "much" should be omitted - than the son of Vedette and Flying Duchess; and in saying this I am quoting the opinion of one who knew the horse well, and certainly was not in the least disposed to underrate the merit of Galopin's most distinguished son, St. Simon aforesaid. It happened that for some years it was my custom during many mornings in every year to ride out and watch the work done by the late John Dawson's string, and it was from him that I gathered what can hardly be a very wrong estimate of Galopin. A famous horse in training at that period was Petrarch, Galopin's senior by a year. Petrarch, a son of Lord Clifden, won the Middle Park Plate, amongst other races, as a two-year-old; as a three-year-old he carried off the Two Thousand Guineas and the Leger; as a four-year-old he took the Ascot Cup. There can be little doubt, none indeed, about his merit, and John Dawson used to tell me that Galopin was always a considerable number of pounds and lengths in front of him. As just remarked, very few horses are found in Turf history who have not failed once or twice, and it is to a great extent because St. 


\section{GALICIA : HER FORBEARS}

Simon and Ormonde were never beaten that they are so highly esteemed. There may be perfectly legitimate excuse for a defeat, possibly for a couple of failures, but these things are not regarded: what men remember is that a hiatus has occurred in the series of winning brackets. Galopin carried well-nigh all before him, but he was not unbeaten. He did not actually win, that is to say come in first for, the Hyde Park Plate at Epsom (1874), which nevertheless stands to his credit. What happened is described in the Racing Calendar for that year. There was an objection, and the report of the race reads :

"We are of opinion that Constable on Cachmere cannoned unintentionally against Morris riding Galopin, which prevented the latter from winning. Galopin is therefore the winner of the Hyde Park Plate, and Cachmere is not entitled to a place.

"C. Alexander.

"W. S. Stirling Crawfurd (for Mr. Chaplin). "H. J. Rous."

The son of Vedette then went on to Ascot, where he started twice, for the Fern Hill Stakes and for the New Stakes, favourite on both occasions at 6 to 4, and he won without difficulty. In the Middle Park Plate his only defeat occurred. A field of twenty-four went to 


\section{AND HER OFFSPRING}

the post, the largest with one exception which has ever assembled: there were thirty starters when Petrarch won next year. Galopin was backed at 6 to $\mathrm{I}$, the favourite being a colt called Holy Friar, the property of the Lincolnshire clergyman who raced under the adopted name of "Mr. Launde," and who is chiefly known in the annals of the Turf as the owner of Apology, the mare who won the One Thousand Guineas, the Oaks, the Leger, and as a fiveyear-old the Ascot Cup. Holy Friar, 2 to I, finished unplaced, there being a great fight between Mr. R. R. Christopher's Plebeian, Lord Dupplin's Per Se, and Galopin, heads only dividing them, and an objection for bumping followed, Tom Cannon on Per Se declaring that he had been prevented from winning by Mordan on Plebeian, whilst Morris appeared to think that with a fair field and no favour Galopin would just have got home. The objection, however, was overruled. This was Galopin's one lapse. Afterwards he was only out twice as a two-year-old and neither race meant anything. He only found one opponent in a sweepstakes at Newmarket, an indifferent colt called Tresorier, whom he beat at his leisure with odds of Ioo to 7 on him, and he then walked over for a small stake at the Second October. 


\section{GALICIA : HER FORBEARS}

As a three-year-old Galopin led off with a match against Mr. Henry Chaplin's Stray Shot, destined to have her name writ large in Turf history as the dam of the Two Thousand and Derby winner Shotover. Galopin was set to give Stray Shot ro lb. over the Rowley Mile; odds of I I to 8 were laid on him, and he won in a canter by eight lengths. The Derby followed, and of this I give a record :

Epsom, I 875 .

The Ninety-sixth Renewal of the Derby Stakes of 50 sovs. each, h. ft. for three-year-olds, colts 8 st. Io lb., and fillies 8 st. $5 \mathrm{lb}$; the second received 300 sovs. and the third I 50 sovs. out of the stakes. About a mile and a half, starting at the New High Level Starting Post. (I 98 subs. - $£_{4950 .)}$

Prince Batthyany's b. c. Galopin, by Vedette . . . . Morris I

Lord Aylesford's b. c. Claremont . . Maidment 2 Lord Falmouth's b. c. Repentance, by Macaroni . . . . . F. Archer 3 Lord Falmouth's b. c. Garterley Bell . H. Jeffery o Mr. Vyner's b. c. Camballo . . . J. Osborne o Lord Aylesford's b. c. Telescope . . Glover o Prince Soltykoff's br. c. Balfe . . T. Cannon o Mr. W. S. Cartwright's b. c. The Bay of

Naples . . . . . Custance O Lord Fitzwilliam's br. c. Breechloader . F. Webb o Mr. H. Savile's b. c. Earl of Dartrey . W. Platt o Mr. John Watson's b. c. Earlston . . Constable o Mr. F. E. Brace's br. c. Fareham . . T. Osborne o 


\section{AND HER OFFSPRING}

Count F. de Lagrange's b. c. Gilbert . Fordham o

Count F. de Lagrange's ch. c. Punch . Carver O

Mr. C. Bush's ch. c. Lord Berners . Parry o

Mr. Jos. Dawson's br. c. Seymour . . C. Wood O

Lord Ailesbury's ch. c. Temple Bar . T. Chaloner o

Mr. F. Swindell's ch. c. Woodlands . J. Groater O

Betting.-2 to I against Galopin, I oo to I 2 Balfe, 9 to 1 Camballo, roo to 8 Repentance colt, 100 to 7 each Claremont and Bay of Naples, 20 to I Woodlands, 22 to I 'Temple Bar, 25 to I each Seymour, Breechloader, and Earl of Dartrey, 30 to I Telescope, 100 to 3 Fareham, I 000 to 15 each Lord Berners and Gilbert, and 100 to I each Garterley Bell and Punch. Won by a length; six lengths between second and third.

Why Galopin's Ascot exertions were confined to the Fern Hill Stakes I am not aware. It seems not a little odd that a Derby winner should have been brought out for a five-furlong race, though the fact is interesting as proof of his remarkable speed. Here he was backed at 2 to I on and won by four lengths. One of the speediest horses then in training was Lowlander, and what was thought of him is proved by the readiness of his owner to make a match with Galopin over the Rowley Mile, $£$ I000, $£ 200$ forfeit. It is remarkable, indeed, that Lowlander, then a fiveyear-old, however, should have attempted to give the Derby winner I 2 1b. That was at the time $4 \mathrm{lb}$. more than weight for age-the scale has been since slightly revised, and at the present 


\section{GALICIA : HER FORBEARS}

time over a mile in October, five-year-old, sixyear-old and aged horses give three-year-olds 7 lb. Galopin, however, won his match, and was only seen once afterwards, when he took the Newmarket Derby, being subsequently sent to stand at Mr. Barrow's establishment at Newmarket at a fee of 100 guineas.

This was the sire of Galicia, and more than passing reference should be made to her maternal grandsire, Isonomy. It is tempting to go back a generation and talk of the sire of Isonomy, Sterling, who must have been a remarkable stayer and weight carrier, though he did not win the races on which reputations are generally founded.

This son of Oxford, dam by Flatcatcher, comes so closely into the record that he must not be hastily passed over. $\mathrm{He}$ was at any rate a remarkable horse. His start was humble enough; he came out for the Castle Park Stakes at Warwick, 5 sovs. each, 50 addedin his day it will be perceived the minimum had not been raised to £Ioo. He started at evens and was beaten two lengths by a filly called Miss Lizzie, who never seems to have done anything. Sterling made some mark later in the season, however, for he won the Hopeful and the Rutland Stakes at the Newmarket First October Meeting. 


\section{AND HER OFFSPRING}

As a three-year-old the colt flew at high game, making his first appearance in the Two Thousand Guineas, in which Bothwell beat him a length. A well-known animal at this time was King of the Forest, whose form with Sterling must have perplexed those who endeavoured to derive guidance from it. In the Two Thousand Guineas King of the Forest finished third, three lengths behind Sterling. In the Prince of Wales's Stakes at Ascot Sterling's ability to stay seemed likely to give him a stronger advantage over the colt he had beaten at Newmarket, especially as King of the Forest carried 9 st. I lb., Sterling 8 st. I $3 \mathrm{lb}$. The former, however, won the race, Sterling not in the first three, and as a matter of course when they met at evens in a Biennial two days later odds were laid on King of the Forest. This time Sterling won by three lengths! He had a busy three-year-old season. At the Newmarket July he won the Summer Stakes, carrying 8 st. I 2 lb., from Azalea, 6 st. 4 lb., and Piquillo, 6 st. 2 lb. This was good, and his performance in the Chesterfield Cup at Goodwood far from bad, as he failed by only a length to give the winner 33 lb. In the Great Eastern Railway Handicap he was burdened with 9 st. $6 \mathrm{lb}$. This race, by the way, led to trouble, some of the jockeys being reported by the starter. Archer was sus- 


\section{GALICIA : HER FORBEARS}

pended "from September 28th to October I 2th, both days inclusive," the sentence ran, Wheeler having to stop riding on the same date, his sentence being extended to the igth. The extra week seems to show nice discrimination on the part of the Stewards. In the Cambridgeshire, one of the most sensational races for that handicap ever known, Sterling had 8 st. I I 1 b. and ran a dead heat for second place with Allbrook, 5 years, 6 st. 9 lb., Sabinus, 4 years, 8 st. 7 lb., winning by a head. Henry was favourite for this Cambridgeshire, and is returned at the unusual odds of 17 to 4 -one would have thought that 4 to I was near enough; and two Derby winners ran-Favonius, then, of course, a three-year-old, in at the same weight as Sterling, backed at I I to 2, and Kingcraft, the winner of the previous year, 8 st. 4 lb., an outsider at 40 to I. Sterling, it will be seen, had lost the Two Thousand by a length, and in the autumn at Newmarket finished several, if not many, lengths before the Derby winner of the year. Sterling's last appearance of the season was in the Free Handicap for ThreeYear-Olds, which he won carrying 8 st. 6 lb.

As a four-year-old he did little. The Craven Stakes was at this period, I87r, an optional Selling Race, worth $£ \mathrm{I} 75$, and this represented the whole of the colt's winnings for the season. 


\section{AND HER OFFSPRING}

He ran for the Gold Vase at Ascot, favourite at 7 to 4 , and was beaten half a length by Albert Victor at ro to I, his last effort being in the All-aged Stakes, which on that occasion was certainly remarkable. The distance, it is perhaps needless to observe, is something over five furlongs, and the runners were, besides Sterlingwho as just remarked had been out for the twomile Gold Vase on the Tuesday of the Meeting, and was indeed an unquestionable stayer-Prince Charlie, who had run second for the Leger, and Wenlock, who had carried off the Doncaster classic. I do not remember any occasion on which three horses with such records have contested a sprint race.

As for the Cambridgeshire, the race is described by Sterling's jockey in the volume of his Riding Recollcctions and Turf Stories. Custance writes: "It was an unlucky day for me when I rode Sterling in the Cambridgeshire. It rained in torrents and was dreadfully cold; I had been wasting for other races, and we were about threequarters of an hour at the post. There were thirty-seven runners, and Sterling, who had behaved himself pretty well the first ten minutes, became almost unmanageable afterwards. $\mathrm{He}$ reared, kicked, and did everything he should not have done, as his temper was upset. At last the 


\section{GALICIA : HER FORBEARS}

flag fell to a straggling start, and before we had gone two hundred yards I was in the first three with 9 st. $7 \mathrm{lb}$. When we had gone a quarter of a mile I was second, with my reins like soft soap. I ought really to have been about nineteenth or twentieth, with top weight on, but it could not be helped, as I was perfectly helpless; my hands were numbed, and the sweat from the horse's neck made the reins quite past holding-in fact I was under every possible disadvantage, though I finished third."

Elsewhere in the book Custance writes: "It is quite impossible for me to mention all the fine races I have seen Fordham ride. With one especially I was very much impressed, and so were many others who will corroborate me. This was when he won the Cambridgeshire of 187 I on Sabinus. This race especially was most beautifully timed and resolutely finished." It thus appears that Sterling must have been unlucky not to win. Fine weather, avoidance of long delay at the start, and an ordinary jockey instead of the redoubtable Fordham on Sabinus, might well have altered the result.

An idea seems to exist-I have read it more than once, for when a blunder appears in print it is frequently reproduced-that Isonomy never ran as a two-year-old. As a matter of fact he 


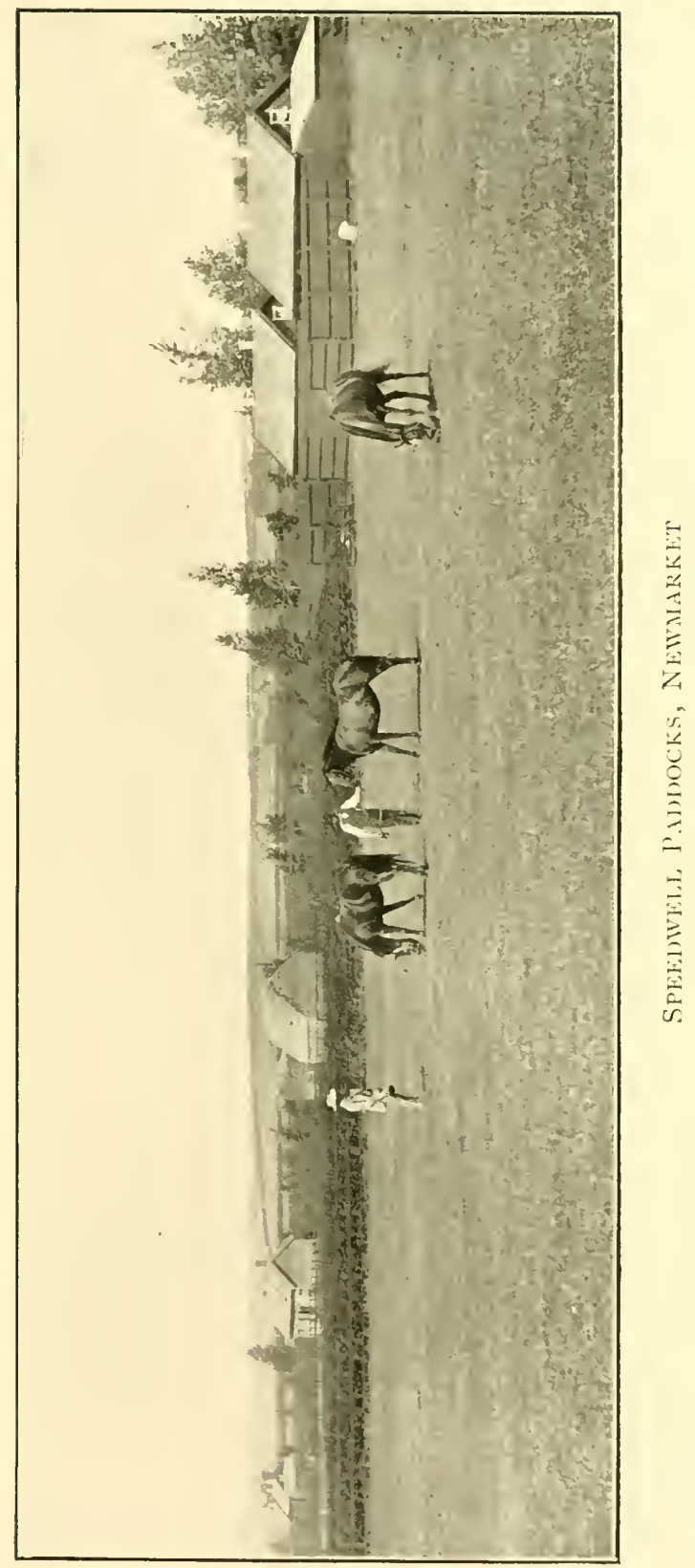





\section{AND HER OFFSPRING}

did so thrice, making his first appearance in 1877 in the Brighton Club Two-Year-Old Stakes. Something was thought of him, for he was backed at 9 to 4 , the race going to an evenmoney favourite, Mr. Ellerlie's Ersila, by Rosicrucian, one of three colts-the other two being Blue Gown and Green Sleeves-between whom Sir Joseph Hawley seems to have been unable to make up his mind before the Derby of i 868. In this Brighton race Isonomy was a bad third. He came out again for the Second Nursery at Newmarket First October Meeting, and, an 8 to I chance, won by half a length from the then Lord Lonsdale's Telegram, backed at half the price. His third outing was in a Nursery at the Houghton Meeting. Here he was not mentioned in the betting, but was only beaten a head by Mr. C. Best's Beadman in receipt of I I $1 b$. Of course there was nothing in all this to suggest that Isonomy was more than a moderate animal, very moderate perhaps; but he made exceptional improvement, and next year it was decided by his owner, Mr. F. Gretton, to keep him for the Cambridgeshire, for which he was specially trained. In the circumstances, having done so little the previous season, it cannot be said that he was leniently treated with 7 st. I lb., and as will be seen from the record he started 


\section{GALICIA : HER FORBEARS}

at the comfortable odds of 40 to I. Details follow :

Newmarket, I 878 .

The Cambridgeshire Stakes (handicap) of 25 sovs. each, Io ft. and 5 only if declared by noon on September I oth, with 300 added; the second received I oo sovs. out of the stakes, and the third saved his stake; winners extra; entrance 3 sovs. Cambridgeshire Course. (I 7 I subs., 48 of whom paid 5 sovs. each$£ 2$ I 87.$)$

Mr. F. Gretton's Isonomy, by Sterling,

3 yrs., 7 st. I lb. . . . Morgan

I

Lord Rosebery's Touchet, 4 yrs., 7 st. 7 lb. . . . Fordham 2

Mr. R. Peck's La Merveille, 3 yrs., 6 st. 3 lb. . . . . Hopper 3

Lord Ellesmere's Hampton, 6 yrs., 9 st.

$3 \mathrm{lb}$.

Mr. Pulteney's Placida, 4 yrs., 8 st. 9 lb. H. Jeffery

Mr. C. Alexander's Thunderstone, 4 yrs.,

8 st. 3 lb. •. . .

Mr. T. Jenning's Ecossais, aged, 8 st.

3 lb. (inc. 5 lb. extra) . J. Goater o

Duke of Hamilton's Midlothian, 4 yrs.,

8 st. I 1 b.

Huxtable o

Lord Falmouth's Lady Golightly, 4 yrs.,

8 st.

J. Morris o

Duke of St. Alban's Lord Clive, 3 yrs.,

7 st. I I lb. (car. 7 st. I 3 lb.) . Snowden

Mr. R. C. Naylor's Jester, 5 yrs., 7 st.

9 lb. (inc. I 4 lb. extra) . . A. Wood

Mr. J. Prat's Faisan, 3 yrs., 7 st. 7 lb. Fagan

Count F. de Lagrange's Clementine,

3 yrs., 7 st. 6 lb.

Constable o

\section{3}




\section{AND HER OFFSPRING}

Lord Bradford's Manœuvre, 4 yrs., 7 st.

$5 \mathrm{lb}$.

Count F. de Lagrange's Lina, 5 yrs.,

7 st. 5 lb. (inc. ro lb. extra, car.

7 st. 6 lb.)

Baron A. de Rothschild's Brie, 3 yrs.,

7 st. 4 lb.

Mr. F. Gretton's Harbinger, 4 yrs., 7 st.

$4 \mathrm{lb}$

Mr. M. H. Sanford's Start, 4 yrs., 7 st.

3 lb. . . . . H. Covey O

M. Delatre's Clocher, 3 yrs., 7 st. 3 lb. Spreoty o

Mr. J. H. Houldsworth's Attalus, 4 yrs.,

7 st. 3 lb. ‥ .

Capt. Machell's Master Kildare, 3 yrs.,

7 st. 3 lb. A. Baltazzi's Tallos, 4 yrs., 7 st. 2 lb.

Hopkins $\quad 0$

J. Watts 0

Mr. A. Baltazzi's Tallos, 4 yrs., 7 st. 2 lb. J. M'Donald O

Duke of Hamilton's Greenback, 3 yrs.,

7 st. I lb. . . . . Lemaire

Count de Juigne's Mantille, 3 yrs., 7 st.

I lb.

Fern

Prince Batthyany's Sidonia, 4 yrs., 7 st. Luke

W. M'Donald O

Mr. E. Etches's Lancaster, 4 yrs., 7 st.

Capt. Machell's Sign Manual, 4 yrs.,

6 st. $12 \mathrm{lb}$.

Mr. C. Perkins's Roehampton, 5 yrs.,

6 st. I 2 lb. . . .

Lord Anglesey's Grey Friar, 4 yrs.,

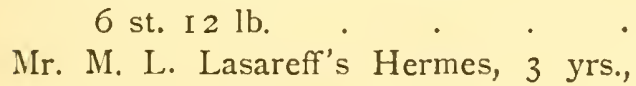

6 st. Io lb. • . 6 .

Mr. W. Goater's Pero, 3 yrs., 6 st. ro lb.

(car. 6 st. I I lb.)

Greaves

Weedon $\quad 0$

Heather $\quad 0$

Baines $\quad 0$

Mr. J. Johnson's Shillelagh, 4 yrs., 6 st. $9 \mathrm{lb}$. 


\section{GALICIA : HER FORBEARS}

Lord Alington's Thistle, 3 yrs., 6 st. 9 lb. Jones

$\circ$

Mr. T. L. Reed's Macbeth, 3 yrs., 6 st.

$5 \mathrm{lb}$. . ${ }^{\circ}$.

Mr. J. N. Barlow's Knighthood, 3 yrs.,

6 st. 3 lb.

A. Hall o

Kendall $\quad 0$

Mr. G. Lambert's Edith Plantagenet, 3 yrs., 6 st. . . . . .

Mr. Whittaker's Miss Pool, 3 yrs., 5 st.

I $3 \mathrm{lb}$.

Collins

○

Bell

O

Mr. W. S. Crawfurd's Broad Corrie, 3

yrs., 5 st. I 2 lb. (car. 5 st. I 3 lb.) Gallon

O

Betting.-I $\mathrm{IO}$ to I 5 each against Macbeth and Greenback, 8 to I Tallos, Io to I Touchet, Ioo to 8 Placida, 100 to 7 Start, I 00 to 6 each Lord Clive and Master Kildare, 20 to I Hampton, 25 to I each Thunderstone, La Merveille, Sidonia, and Shillelagh, 33 to I each Ecossais and Brie, 40 to I each Roehampton, Clocher, and Isonomy, 50 to I each Mantille, Jester, Sign Manual, Manœuvre, and Lancaster, I oo to I each Lady Golightly, Clementine, Faisan, Lina, Attalus, Broad Corrie, Miss Pool, Edith Plantagenet, and Grey Friar. Won by two lengths, half a length between second and third, and a head between third and fourth.

After this his career was one of almost uninterrupted success. As a four-year-old he ran for the Ascot Gold Vase, one of his two opponents being Lord Falmouth's Silvio-who had won the Derby of 1877 -and on whom 9 to 4 was laid, Archer riding; but Tom Cannon on Isonomy, I I to 4 , beat him half a length. Two days afterwards he was saddled for the Ascot Cup. There were six starters, and, favourite at 2 to $\mathrm{I}$, he took the I 6 


\section{AND HER OFFSPRING}

trophy, following on with the Goodwood Cup, and the subsequent week the Brighton Cup, which was then a two-mile race. In the Ebor Handicap he had 9 st. $8 \mathrm{lb}$., which did not deter backers from laying i $\mathrm{I}$ to 8 on him. He won this, and going on to Doncaster added the Cup there to his spoils, Ioo to 15 on, though this time there was nothing to spare, as he only got home by a head from Lord Falmouth's Jannette, who had carried off the Leger of the previous year. Isonomy had 9 st. Io $\mathrm{lb}$. in the Cesarewitch, a burden which has never been borne successfully-the 9 st. $5 \mathrm{lb}$. of Willonyx is the record. Isonomy was set to give no less a weight than $33 \mathrm{lb}$. to the good, honest, staying Chippendale, and it detracts little from his character that he could not do so.

As a five-year-old Isonomy was only out twice, on the first occasion in the Manchester Cup, then run over a mile and five furlongs-the distance is now a mile and a half. There were twenty-one starters. Isonomy carried 9 st. I $2 \mathrm{lb}$., and as his merit was not even yet fully recognised I6 to I was laid against him, joint favourites being The Abbot and Blue Blood, 6 to $\mathrm{I}$. Isonomy won by a neck from The Abbot, giving him 3 st. $3 \mathrm{lb}$; the second, as a three-yearold in May, had the great advantage of $20 \mathrm{lb}$.; 


\section{GALICIA : HER FORBEARS}

Isonomy, therefore, comes out nearly 2 st. the better. His other race was the Gold Cup, in which he was opposed by Chippendale and the French colt Zut. Seeing what had happened in the Cesarewitch it is not in the least strange that 9 to 4 should have been laid on Isonomy, though it does seem curious that backers should have been found ready to take 95 to 40 about Chippendale, meeting his former conqueror with no advantage, there being, it is probably needless to add, no penalties or allowances in this race.

Few horses have had a more brilliant career at the stud, Isonomy's offspring including Common, Isinglass, and a host of notable winners, amongst whom, however, his daughter Isoletta is not included. Like so many other mares famous for what they have produced she was no good as a racer, and indeed her daughter Galicia did little, as to which it can only be said that, as usual with her owner's animals, an ambitious programme was mapped out for her.

Galicia first ran for the Kempton Park TwoYear-Old Plate on the 2nd of June 1900.

Kempton Park, 1900.

The Kempton Park Two-Year-Old Plate of 800 sovs. for the owner and roo sovs. for the nominator of the winner, and 50 sovs. each for the owner and nominator of the second; entrance 15 sovs., or 3 


\section{AND HER OFFSPRING}

sovs. if declared; five furlongs, on the Straight Course. (99 subs., 48 of whom paid 3 sovs. each $-£ S S_{5}$.)

Mr. R. S. Sievier's Toddington, by Mclton, 9 st. 2 lb. . . . S. Loates I Mr. A. Cohen's Royal River, S st. 9 lb. . O. Madden 2 Mr. Fairie's Galicia, 8 st. 9 lb. . . K. Cannon 3 M. Ephrussi's Mirande, 9 st. 2 lb. . . T. Loates o Mr. J. Musker's Britannia, 9 st. 2 lb. . Sloan o Lord W. Beresford's Petronius, 8 st. I $2 \mathrm{lb}$. . J. Reiff O Lord W. Beresford's Volodyovski, S st.

I 2 lb.

Mr. E. Hobson's Lambourn Belle, 8 st. 9 lb. . • • • . F. Rickaby 0 Mr. P. Lorillard's Revera, 8 st. 9 lb. . L. Reiff O Duke of Portland's St. Aldegonde, 8 st. $9 \mathrm{lb}$. . . . . . M. Cannon o Mr. L. Pilkington's Elleray, 8 st. 6 lb. . Allsopp

Betting.-I I to Io against Toddington, 5 to I St. Aldegonde, I I to 2 Britannia, $S$ to I Mirande, and Ioo to $S$ each Volodyovski and Galicia. Won by a neck, four lengths between second and third.

It will be seen that at any rate she beat the future winner of the Derby, and her next attempt at Ascot was a successful one.

Ascot, 1900 .

The first year of the forty-third Ascot Biennial Stakes of 10 sovs. each, with 500 added, for two-year-olds; second received ro per cent. of the stakes. T.Y.C. (88 subs.—£ 1232 .) 


\section{GALICIA : HER FORBEARS}

Mr. Fairie's Galicia, by Galopin, 8st. Io $\mathrm{lb}$.

K. Cannon I

Sir R. Waldie Griffith's br. f. by St.

Simon-Sweet Duchess, 8st. 1olb. J. H. Martin 2

Mr. G. F. Fawcett's Tin Soldier, 8 st. Io $\mathrm{lb}$.

H.R.H. Prince of Wales' Lord Quex,

F. Rickaby 3 9 st.

M. Cannon o Lord W. Beresford's Nahlband, 9 st. . T. Weldon o Sir E. Cassel's Sang Bleu, 9 st. . . L. Reiff O Mr. Arthur James' Fortunatus, 9 st. . O. Madden O Sir J. Kelk's O'Donoghue, 9 st. . Allsopp O Lord Rosebery's Menander, 9 st. . C. Wood o Lord Crewe's Saltatrix, 8 st. Io lb. . T. Loates o Lord Ellesmere's Sabrinetta, 9 st. I lb. S. Loates o Sir S. Scott's br. g. by Kilwarlin-Jewel

Song, 8 st. Io lb. . . . Fagan

0

Betting. - 2 to I against Sabrinetta, 7 to 2 the Sweet Duchess filly, 5 to I each Sang Bleu and Tin Soldier, and Io to I each Lord Quex and Galicia. Won by half a length, a length and a half between second and third.

But this was her only victory. She ran for the Exeter Stakes at the Newmarket First July, when a serious accident befell her.

Newmarket, 1900.

The Exeter Stakes of $£ 1046$ for two-year-olds. Exeter Stakes Course, six furlongs.

Sir Ernest Cassel's Sang Bleu, 8 st. I $2 \mathrm{lb}$. L. Reiff I Lord Ellesmere's Sabrinetta, 8 st. I $3 \mathrm{lb}$. . S. Loates 


\section{AND HER OFFSPRING}

Mr. J. S. Curtis's Joe's Luck, 8 st.

9 lb. . . . . . E. Jones 3

Sir Samuel Scott's g. by Kilwarlin-

Jewel Song, 8 st. 9 lb. . . K. Cannon +

Mr. J. Musker's The General, 8 st.

I 2 lb. . . . . J. Sloan 5

Mr. Fairie's Galicia, 9 st. 3 lb. . . M. Cannon 6

Mr. P. Lorillard's Tantalus, $S$ st.

I 2 lb. • . . . . B. Rigby 7

Mr. J. P. Larnack's c. by Chillington-

Manœuvre, 8 st. I $2 \mathrm{lb}$. . . O. Madden O

Mr. Whitney's Attaché, 8 st. I 2 lb. . M'Allister O

Sir R. Waldie Griffith's Glim, 8 st. 9 lb. J. H. Martin O

Betting.-I I to Io The General, 5 to I Sabrinetta and Galicia, 8 to I Joe's Luck, Io to I Sang Bleu, I 00 to 7 others. Won by length and a half; length second and third.

According to the evidence of her jockeyand Mornington Cannon was one upon whose statements implicit dependence could be placedGalicia was winning in a canter when she suddenly faltered, and it was found that she had split her pastern. She was never anything like the same mare afterwards.

She came out as a three-year-old for the One Thousand Guineas, and, quoted at 100 to 8 , ran nowhere behind the favourite Sir James Miller's Aida, I 3 to 8 . Then followed the Oaks, taken by the American mare Cap and Bells II, who had never run in England before and who was 


\section{GALICIA : HER FORBEARS}

never seen again. Galicia was seventh for the Coronation Stakes at Ascot. For a Triennial Produce Stakes at the Newmarket First October Meeting she was fourth, in front, however, of the favourite, Veles.

Newmarket, I 901 .

The second year of the fifty-third Triennial Produce Stakes of Io sovs, each, h. ft. for acceptors, with 400 sovs. added for the owner and IOO sovs. for the nominator of the winner; for three-year-olds; second received Io per cent. and third 5 per cent. of the whole stake; entrance 3 sovs, each year, the only forfeit if declared by October IO, I 899. A.F. (79 subs., 24 of whom paid entrance only$£ 675$, Ios.)

Mr. J. H. Houldsworth's Energetic, by Enthusiast, 8 st. Io lb. . . O. Madden I Lord Harewood's O'Donoghue, 9 st. . Maher 2 Sir J. Blundell Maple's The Bishop, 9 st. $5 \mathrm{lb}$.

S. Loates

Mr. Fairie's Galicia, S st. I I lb. . Halsey 3

Sir R. Waldie Griffith's Veles, 9 st. $5 \mathrm{lb}$

- J. H. Martin o Major E. W. Baird's St. Monans, 9 st. F. Rickaby o Mr. Arthur James' Cynical, 9 st. . M. Cannon o

Betting. - 7 to 4 against Veles, 7 to 2 O'Donoghue, 7 to I Energetic, 100 to $\mathrm{I} 2$ each The Bishop, St. Monans, and Cynical, and 100 to 8 Galicia. Won by three-quarters of a length, the same between second and third.

Her last appearance was in the Derby Cup. Here she was out by herself. Her jockey re- 


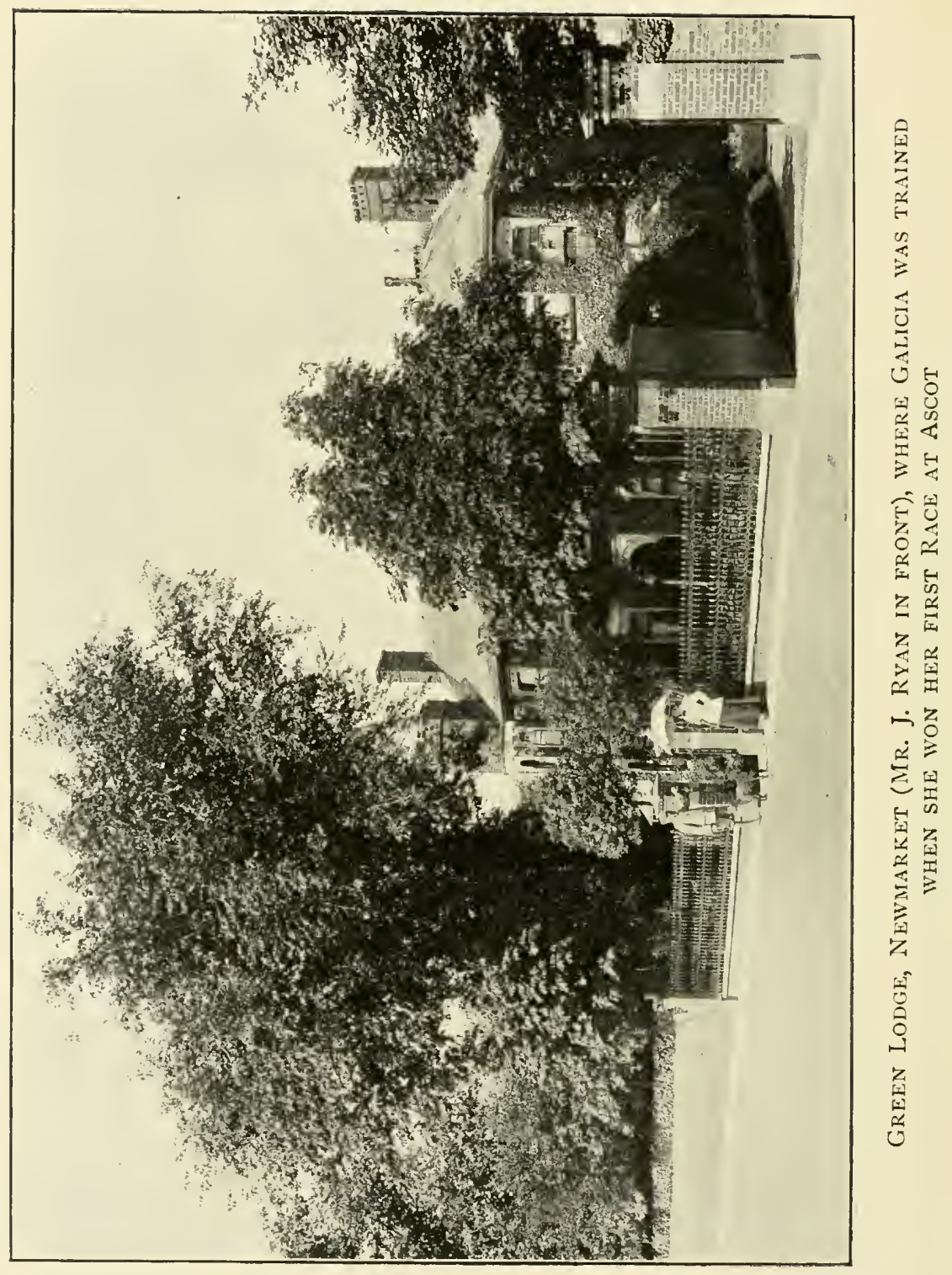




\section{AND HER OFFSPRING}

garded the race as won, when she broke down badly, stopped " as if she had been shot," to quote the familiar phrase, and could never run again.

Galicia was first of all sent to Eager, with a disappointing result. She had no foal; but with regard to this horse something more than casual passing reference seems desirable, for Eager, prior to the appearance of the great horses with whom Mr. Fairie's name will always be associated in Turf history, was at least an animal of special note. Eager was a son of Enthusiast, whose victory in the Two Thousand Guineas of I $S S 9$ remains one of the most extraordinary things on record. Enthusiast was the property of $\mathrm{Mr}$. Douglas Baird, one of the four owners whose horses were trained at this period by James Ryan at Green Lodge, which overlooks the Severals at Newmarket. There were, besides Mr. Fairie, Mr. Douglas Baird and Mr. J. H. Houldsworth, both members of the Jockey Club, and $\mathrm{Mr}$. John Wallace. It may certainly be said that the trainer was fortunate in his patrons, as likewise that they were most efficiently served. Enthusiast beat the Duke of Portland's famous Donovan, Mr. Douglas Baird's colt being one of the three who got their heads in front of this wellnigh invincible horse during his career. There 


\section{GALICIA : HER FORBEARS}

can be no doubt that the victory was purely attributable to jockeyship, indeed Tom Cannon-who wore Mr. Douglas Baird's crimson, silver-braided jacket on this occasion, as on many others-gave me his explanation soon after the race. The chief danger to Donovan, so far as any might be supposed to exist, was "Mr. Abington's" Pioneer, and Tom Cannon beat him and Donovan by what at present seems to be considered the old-fashioned expedient of waiting, a method which nevertheless appears to be returning somewhat to vogue. "They had two little races all to themselves a good long way from the post," was Tom Cannon's description, "and when they started on a third I thought I would join in!" He did this with such admirable effect that he beat Donovan a head, a result which past and future form, direct and collateral, proved to be ridiculously wrong. Enthusiast met Donovan more than once afterwards but never got near him.

Mr. Fairie, however, thought sufficiently well of Enthusiast to send his mare Greeba to him; and Eager, their son, made his first appearance on any course at Lincoln for the Brocklesby Stakes of 1896 , ridden by F. Pratt, now known as a successful trainer, and a nephew of the famous Fred Archer. Eager, almost favourite, 


\section{AND HER OFFSPRING}

backed at 9 to 2, the actual favourite being $\mathrm{Mr}$. Leopold de Rothschild's Jest, finished third to this filly, but soon started on a notably victorious career, deservedly earning the character of being one of the speediest horses of his generation. He won the Royal Two-Year-Old Plate at Kempton at his second attempt, a race worth $£_{27} 80$, from Lord Rosebery's well-known mare Chelàndry, who was to become dam of good horses, including Neil Gow, an animal destined to be closely associated with the fortunes of one of Galicia's two best sons. This opportunity may be taken of correcting an impression which largely prevails to the effect that Eager was merely a six-furlong horse. His great speed made him extraordinarily formidable over this distance, but some of his most notable achievements were in mile races, and sometimes, moreover, over miles on severe courses, the Rowley and the Bunbury amongst others. The greater part of the money he won was in these contests.

As a three-year-old he ran in Galtee More's Derby, which, however, the odds of 50 to I against him suggest that he was not expected to win. Galtee More started at 4 to I on. At Ascot, Eager won the Rous Memorial over the Hunt Cup course, the Midsummer Plate at Newmarket up the steep Bunbury Hill, the Brighton and 


\section{GALICIA : HER FORBEARS}

Derby Cups. A curious circumstance about this horse was that he constantly encountered Goletta and she always beat him, though Mr. Leopold de Rothschild has admitted to me that he does not believe his mare was really the better of the two. Their first encounter was in the Chesterfield Stakes at the Newmarket Second July, when Goletta - like Galicia a daughter of Galopin - was regarded as a practical certainty, and started at 7 to 2 on. Against Eager 4 to I was laid, and he was beaten a short head. The two then met in the Rous Memorial at the Newmarket First October, and Eager failed by a head for the second time. In the Criterion the pair were again opponents; this time Goletta was second to King Edward's Oakdene, who had, however, an advantage in the weights, Eager fourth. As three-yearolds Eager, having won the Rous Memorial at Ascot and the Midsummer Plate aforesaid incidentally, resumed his antagonism with Goletta in the St. George Stakes at Liverpool. Here 5 to 2 was laid on him, notwithstanding that the distance was a mile and three furlongs, which may be accepted as having been beyond his tether; but Goletta was giving him a pound instead of receiving a sex allowance. She beat him by five lengths. Perhaps Eager was never 26 



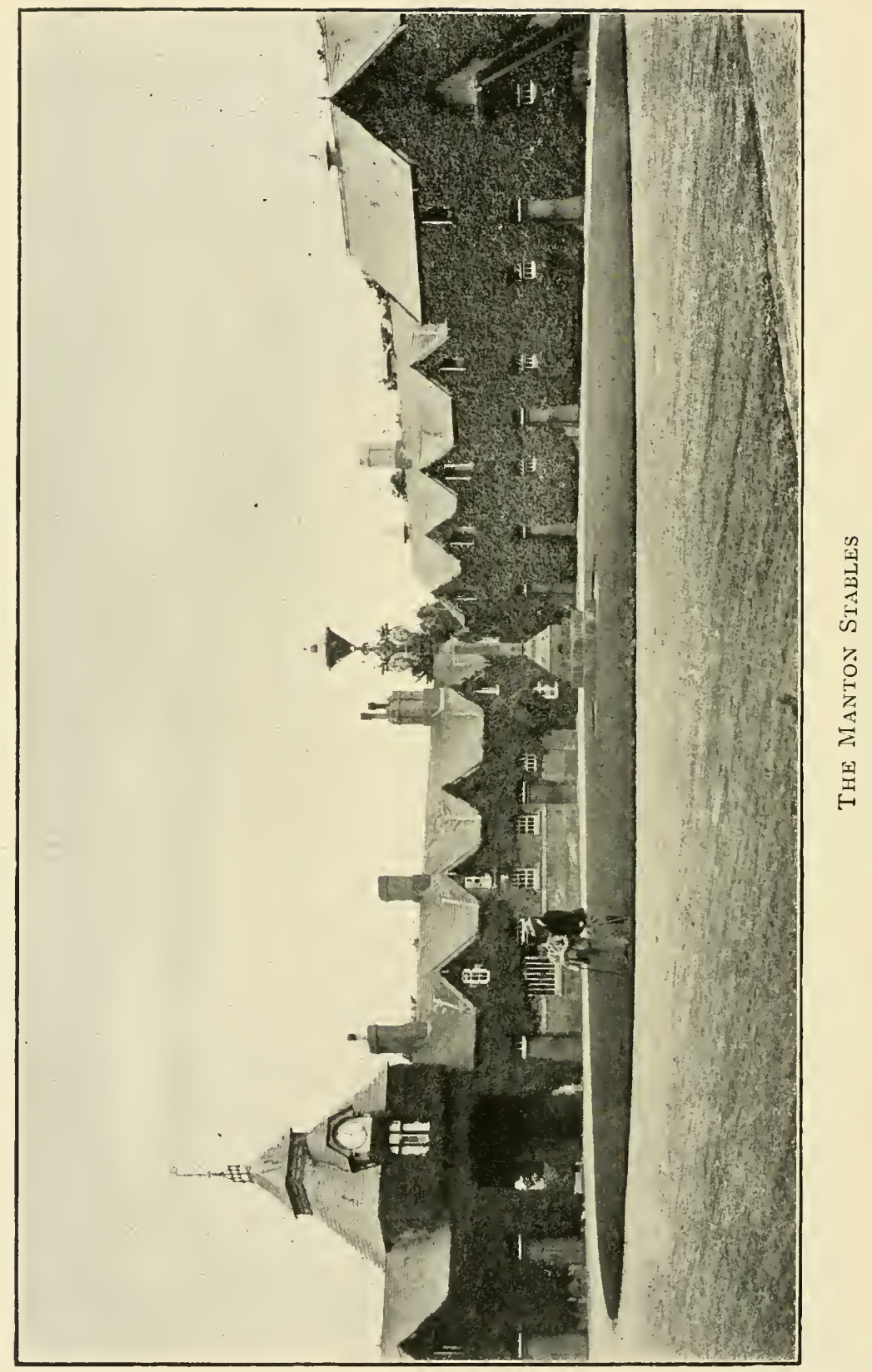




\section{AND HER OFFSPRING}

better than as a four-year-old, when he won the Portland Plate, the Duchess of York Stakes, and other races, failing only by a head in the Derby Cup, carrying 9 st. $6 \mathrm{lb}$., and giving $39 \mathrm{lb}$. to the winner, Waterhen, a useful filly of his own age. During four seasons he carried Mr. Fairie's white, orange sleeves and cap, but as a six-year-old became the property of Mr. L. Neumann, for whom he continued to win races. The horse had very small feet and weak ankles. Mr. Fairie did not care to use him as a sire, helping, however, by sending a few mares, to give him a chance; and he did much better at the stud than his original owner anticipated.

Undeterred by the first failure, Mr. Fairie sent Galicia again to Eager in 1903 , and this time she produced a colt who was called Eastern, and so enters into my story. He was a good-looking bay, who did not come to hand till late in the season, indeed it was not until September that Alec Taylor-for the horses had left Ryan's stable at Newmarket and gone to Manton-was able to bring him out in the Breeders' Foal Plate at Kempton Park. Major Eustace Loder's Galvani had acquired the reputation of being in all probability the best of his year, and odds of I I to 4 were laid on him. I have a vivid recollection of the race, as whilst 


\section{GALICIA : HER FORBEARS}

it was being run I happened to stand by Lord Rosebery, whose Bezonian, in receipt of $10 \mathrm{lb}$, beat the favourite by a neck, though the owner of the winner had told me he entertained no hope of success. Lady de Bathe's Yentoi, who was to win the Cesarewitch two years later, was the only one quoted in the market with the exceptions of Galvani and of Bezonian ( 10 to I), Eastern figuring among the " 25 to I others"; but he showed some speed, and little more than a fortnight afterwards, at the Newmarket First October Meeting-we are talking of 1906-easily won a Triennial Produce Stakes. He did not beat very much; the two animals who followed him home, however, Lady de Bathe's Petchora and Sir R. Waldie Griffith's The Ring, had both won races, and it was demonstrated that Eastern was at any rate useful. He ran in the Prendergast without distinction, and only made one other appearance as a two-year-old, when he was second for a Nursery at Liverpool, in which, however, there were only three starters, and the best that can be made of it is that he was giving the winner $18 \mathrm{lb}$.

I have never agreed with an idea which is held by some people that a horse is necessarily unlucky when he runs second. In these cases a stronger inference is that the winner would have been unfortunate had he been beaten. Eastern 28 


\section{AND HER OFFSPRING}

as a three-year-old was second on no fewer than six occasions, and he was thrice third, moreover, actually winning only one race in fourteen attempts, and that by no more than a head. $\mathrm{He}$ came out for the Column Produce Stakes, in which the Duke of Devonshire's Acclaim had half a length the better of him, and in the Newmarket Stakes a month later either he did not do quite so well or Acclaim did better, for here the Duke's colt beat him a head and a length and a half, Linacre separating them. A third attempt, though not successful, was on the whole to Eastern's credit. This was for the $£$ Iooo Hurst Park Yearling Plate. Lord Rosebery's Traquair, another son of Chelàndry, by Ayrshire, was favourite at I I to ro, having been one of the best two-year-olds of his season, though unfortunately touched in the wind. Eastern beat him a neck but was beaten in turn three lengths by Portland Bay, the winner in receipt of $\mathrm{so} \mathrm{lb}$.

For the Trial Stakes at Ascot Eastern met a useful field. Dean Swift won from King Edward's Slim Lad, Eastern third, giving His Majesty's colt, one of the few sons of Laodamia who has ever been any good, 7 lb. He had established himself, indeed, as just a nice, useful colt, likely to win in his turn when the luck was with him. It was not expected that he would beat Lord 


\section{GALICIA : HER FORBEARS}

Derby's Bridge of Canny for the First Foal Stakes at the Newmarket Second July, Bridge of Canny being something more than useful, and winning by a length and a half, giving ro $\mathrm{lb}$. more than weight for age. The Atlantic Stakes at the Liverpool Meeting must not be passed over without reference, for the favourite here was Orby, who had not been seen in England since he won the Derby. Odds of 7 to 4 were laid on him, and he finished last of the four starters, Eastern, however, being no nearer than third. He went to Goodwood and came near to victory in the Chesterfield Cup, where he met really good animals. Velocity, then a five-year-old, was favourite, and obviously deserved the position, as he won, though only by a neck from Eastern, who beat Dean Swift by a length and a half. Eastern and Dean Swift met on exactly the same terms as in the Trial Stakes at Ascot. There Dean Swift had beaten Mr. Fairie's colt four lengths and a half, now, as just observed, it was a length and a half the other way, so that, as it is certain from subsequent performances that Dean Swift was not deteriorating, Eastern must have been coming on. His one victory followed, at Hurst Park in the Lennox Plate in August. Here the favourite was Baltinglass, 6 to 5 on. The son of Isinglass and Sibola, who 


\section{AND HER OFFSPRING}

was to run second for the Leger and start one of the hottest favourites on record for the Cesarewitch, at 9 to 4, was in receipt of $9 \mathrm{lb}$. from Eastern, and Mr. Fairie's colt won by a head. He wound up the season by missing the Free Handicap by a similar margin, All Black giving him I lb. and just beating him. This was Eastern's last appearance in England. The stud-book records that he was sent to Belgium, and what became of him I do not know. He inherited his sire's small feet and weak fetlocks, and his owner had an idea that it often hurt him to stretch himself out, especially when the ground was at all hard. Galicia had, however, taken rank as the dam of a winner.

In 1905 Galicia gave birth to a bay colt by Isinglass who was called Carpathian, and showed sufficient promise to induce Mr. Fairie to put him into the New Stakes at Ascot, the Chesterfield at Newmarket, the Richmond at Goodwood, as also the Rous Memorial and the Molecomb, the Champagne at Doncaster, the Hopeful at Newmarket, the Middle Park and the Dewhurst, the two-year-old races, indeed, in which reputation is to be chiefly won. But Carpathian was never seen on a race-course. Meantime Galicia had visited Bay Ronald, a sire who certainly would not have been everyone's choice. 


\section{GALICIA : HER FORBEARS}

There is one detail which I must not omit. At the time of writing the mare whose offspring have won most money in stakes is understood to be the Duke of Portland's Mowerina, the sire of Donovan, Semolina, and other winners, pressed by King Edward's Perdita II, dam of the three brothers Florizel II, Persimmon and Diamond Jubilee. Galicia is not far from the front, and in all probability her total will be considerably increased. It may be anticipated with no little confidence that she will presently be found to rank as the most remunerative mare who has ever figured in the Stud Book. 


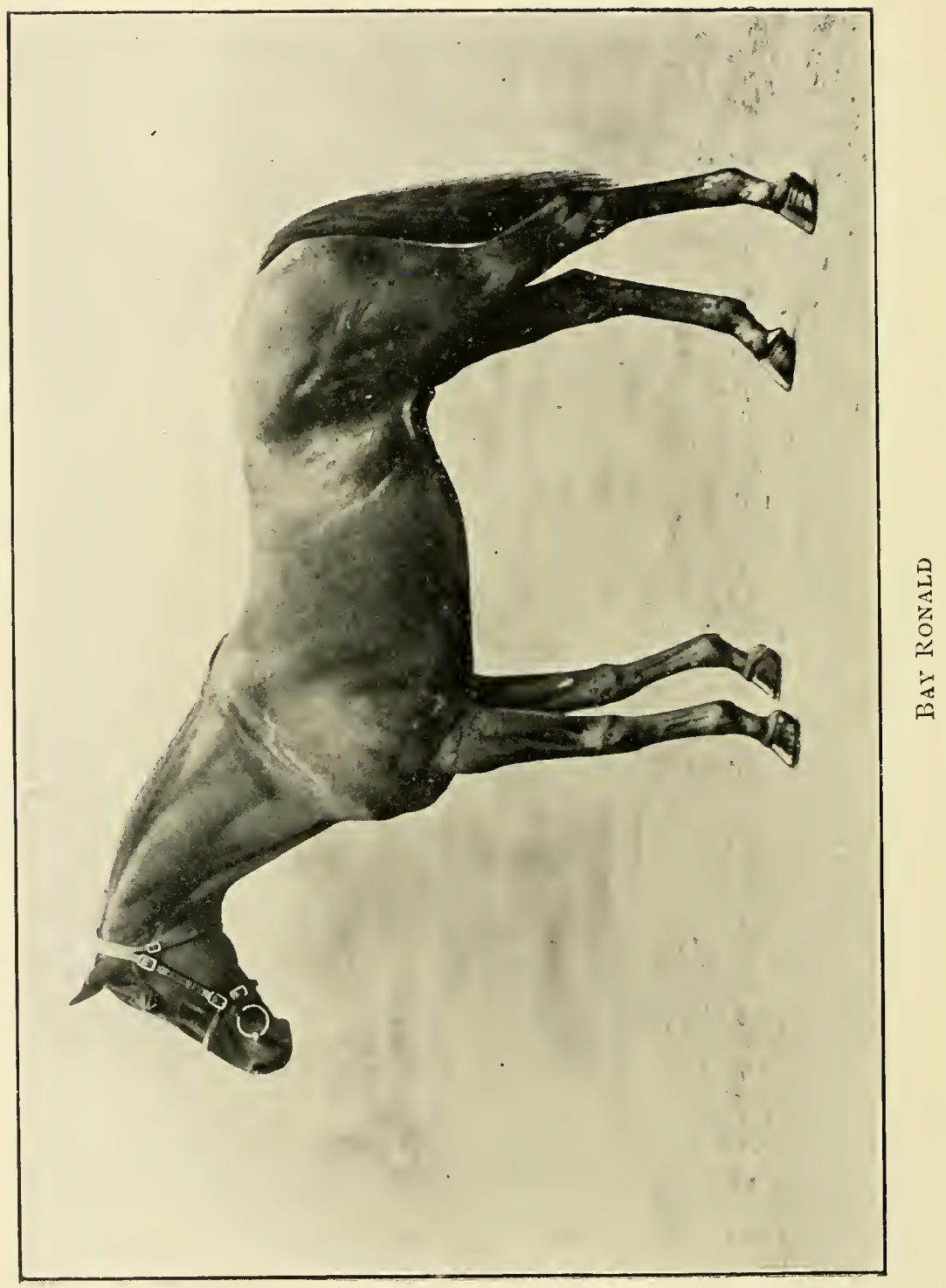




\section{AND HER OFFSPRING}

\section{CHAPTER II}

\section{BAY RONALD}

Bay Ronald was standing at Lordship Farm at a fee of 75 guineas. He had not produced anything of mark, and at this period the list of horses at the stud included many who looked tempting, though as regards most of them there was the question of inbreeding to be considered in dealing with a daughter of Galopin. Popular sires in 1905, however, besides the sons of St. Simon, included Ayrshire, by Hampton-Atalanta; Carbine, by Musket-Mersey; Cyllene, by Bonavista-Arcadia; Gallinule, by Isonomy -Moorhen ; Ladas, by Hampton-Illuminata ; Melton, by Master Kildare-Violet Melrose; Rightaway, by Wisdom-Vanish, all these at fees varying from 100 to 250 guineas, and it may be incidentally observed that Flying Fox, the son of Orme and Vampire, was priced at 600 guineas. Mr. Fairie made choice of Bay Ronald, how wisely the result was to show.

Horses are seldom judged without prejudice. For one of various reasons their critics have a 


\section{GALICIA : HER FORBEARS}

disposition to regard them either with favour or disfavour, and a perfectly true account of almost any horse can be so tinged as to make him appear better or worse than he actually is. Thus as regards Bay Ronald it might be observed that during the four years he remained in training he ran in twenty-six races and won only five of them, the one by which he is best known having been a handicap, the City and Suburban; but no one pretends that such a summary would do the horse anything like justice. It is probable that when Bayardo first began to show what he was some doubts existed as to whether his career would continue brilliantly, simply because Bay Ronald was scarcely a sire from whom great things might have been expected. This is judging him superficially perhaps, by his not very brilliant performances whilst in training; but when his descent was considered it became evident that Bay Ronald might be capable of anything if he came near to transmitting the excellence of those from whom he was descended.

Bay Ronald, the property of Mr. Leonard Brassey, was a son of Hampton and Black Duchess. Hampton himself was a remarkable animal for reasons to which reference will presently be made. He in turn was the son of Lord Clifden, probably one of the best horses 


\section{AND HER OFFSPRING}

in the annals of the Turf, winner of a highly sensational Leger amongst other races. Lord Clifden was by Newminster, another St. Leger winner; Newminster by the famous Touchstone, yet another winner of the Doncaster classic; and on the dam's side Bay Ronald's descent is scarcely less distinguished, his dam having been Black Duchess, by Lord Falmouth's Galliard-a son of Galopin-winner of the Two Thousand Guineas of $\mathrm{I}_{8} 88_{3}$, and of Black Corrie by Sterling.

I must by no means omit somewhat extended comment on Bay Ronald's sire, Hampton. In his early days it cannot be denied that he appeared to be altogether unworthy of his ancestors. $\mathrm{He}$ was somewhat small, though a decidedly good-looking horse, but that he did not take everyone's fancy is sufficiently proved by the fact that after winning a little Selling Race as a two-year-old no one would bid more than $15^{\circ}$ guineas for him, at which modest price he was allowed to change hands. This was in 1874 , and it seemed indiscreetly ambitious to put him into the Metropolitan at Epsom next season, a mere plater, as it could not be incorrect to describe him. Carrying 6 st. $3 \mathrm{lb}$. he won in the style which his two-year-old efforts were very far from suggesting. His improvement was, indeed, astonishing, the fact being, however, that he was 35 


\section{GALICIA : HER FORBEARS}

a natural stayer for whom no course appeared to be too long, and he was also possessed of sufficient speed to do what was necessary at the finish. Even as a four-year-old his merit was scarcely recognised, or so it would seem from the circumstance of his having had no more than 7 st. Io lb. in the Goodwood Stakes. There was certainly a good entry that year; but nothing had a chance with Hampton. I well recollect the race, for a friend of mine, then Mr. Herbert Gardner, created afterwards Lord Burghclere, was also a great friend of the late Lord Ellesmere, Hampton's owner, and induced me to back the horse. Handicappers soon began to perceive what he was. His weight in the Northumberland Plate next year, 1877 , was 8 st. I $2 \mathrm{lb}$., and he had no trouble in beating the fourteen opposed to him.

In his first season there had been no sort of ground to anticipate that Hampton would ever be able to win ordinary handicaps, whereas he proceeded to qualify as a Cup horse, and in 1877 added the Goodwood and Doncaster Cups to the list of his successes. In ${ } \delta_{7} S$ he did better still, taking the Epsom Gold Cup, a race which was then run over two miles, from the French horse Verneuil, who must have been one of the very best ever sent across the Channel. Verneuil was 


\section{AND HER OFFSPRING}

a magnificent specimen of the thoroughbred, and Hampton's fame naturally advanced after the Ascot Meeting; for here Verneuil won the Gold Vase on the Tuesday, the Gold Cup two days later, and was brought out again on the Friday for the Alexandra Plate, which he also secured. These triumphs of Hampton's were all accomplished in Lord Ellesmere's colours, and the once-despised plater became the sire of three Derby winners-Merry Hampton I887, Ayrshire the following year, and Ladas i894and very nearly of a fourth who would have been victorious in the colours of his owner -Highland Chief. This colt was only beaten a neck in ${ } 88_{3}$ by Sir Frederick Johnstone's St. Blaise, and Webb, who rode Highland Chief, pulled up under the confident impression that he had actually won. When the trainer, Charles Archer, drew Webb's attention to the number of St. Blaise displayed above the judge's box, the jockey was persuaded that it must certainly have been hoisted by a mistake which would be speedily rectified. The Two Thousand winner Galliard, ridden by Fred Archer, was, it may be remarked, third. Hampton was also a winner over hurdles, a matter, however, little regarded by devotees of the sport which is called legitimate. He was a good second for the Grand 


\section{GALICIA : HER FORBEARS}

International Hurdle Race at Croydon to Chandos, who possibly never had a superior in this business, which is in a great measure, no doubt, a question of knack. James Jewitt, who used to ride Chandos, has told me that the horse took his hurdles in his stride with a perfect ease which hardly conveyed to his jockey the impression that he was jumping at all. Excellence was, however, only to be expected from a son of Lord Clifden. I have mentioned this horse's sire Newminster; his dam was The Slave, a daughter of Melbourne, whose lop ears, and what was called the "Melbourne blaze," have marked so many of his stock.

Of late years the thoroughbred horse has enormously increased in value. In the sixties 5000 guineas was considered a huge sum to give for any animal, though for Lord Clifden as a twoyear-old Lord St. Vincent is said to have paid over 6000 guineas. Lord Clifden began his career by winning the Woodcote Stakes at Epsom, as several great horses have done, and after having been practically left at the post for the Champagne at Doncaster he won that as easily as he had taken the Epsom race. Another of his twoyear-old exploits was to beat Lord Falmouth's good filly Queen Bertha, winner of the Oaks of 1863. There is little doubt that he was unfortunate in losing the Derby. Some time before $3^{8}$ 


\section{AND HER OFFSPRING}

the race he slipped up and injured himself, with the result that his preparation was seriously interrupted, a fact, I believe, not generally known. What happened on training grounds at that period was not common property, as it usually is to-day. There was in the stable an Irish horse called Bellman who greatly resembled Lord Clifden, and was mistaken for Lord St. Vincent's colt, the consequence being that work which Lord Clifden did not do, being at the time in his stable incapacitated, was attri buted to him. He was decidedly backward in condition at Epsom, but nevertheless only failed by a head to beat Macaroni. There were good horses behind him-Rapid Rhone, The Ranger who won the first Grand Prix, Saccharometer, Blue Mantle, and Hospodar. Lord Clifden's St. Leger was one of the most sensational on record. He was ridden by John Osborne and left at the post, to all appearances hopelessly out of it. To have hurried him would doubtless have been fatal, but his accomplished jockey allowed him to make up his ground gradually, so much so that at the Red House it is said he was fully fifty lengths last, and odds of 50 to I were shouted against him. By degrees he pulled his way to the front, winning comfortably by half a length from Queen Bertha, Borealis third, in 39 


\section{GALICIA : HER FORBEARS}

front of The Ranger and Blue Mantle amongst others. The grandsire of Bay Ronald was also the sire of no fewer than four Leger winnersHawthornden, 1870 ; Wenlock, 1872 ; Petrarch, 1876 ; and Jannette, I 878 .

Newminster must not be omitted from comment. He too won the Leger, in $185 \mathrm{I}$, and besides Lord Clifden, sired classic winners in Musjid, who carried off the Derby for Sir Joseph Hawley in I869, and Mr. Chaplin's Hermit, victorious at Epsom in i867. Hermit became one of the most famous sires in Turf history, his stock including the classic winners St. Blaise, Shotover, Thebais, St. Marguerite, and Lonely. Peter, Tristan, Queen Adelaide and St. Louis were likewise by him, as was Friar's Balsam, unquestionably the best two-year-old of his season. Odds of 3 to I were laid on Friar's Balsam for the Two Thousand Guineas of I888, but on the way to the post an abscess which had formed in his mouth, and in some mysterious way escaped the observation of his trainer, broke, and he was quite unable to do himself anything distantly approaching to justice. In the New Stakes at Ascot Friar's Balsam had cantered away from the Duke of Portland's Ayrshire, who won the Derby, having previously 40 


\section{AND HER OFFSPRING}

taken the Two Thousand which Friar's Balsam missed. It will be seen how many of this family were winners of the Leger. Touchstone was so in I 834, taking also the Doncaster Cup next year and the Ascot Cup, as also the Doncaster Cup again in $8_{3} 6$, and his Ascot victory he repeated in 1837 . When it is considered what these horses did, respect for their descendant Bay Ronald cannot but increase.

Coming to Bay Ronald himself it has been said that he merely won five races in four years; but in order to give a fair view of him it must be pointed out that the tasks set him were frequently severe. His first appearance was made in the Stanley Stakes at the Epsom Summer Meeting of I 895 , when as he started at Io to $\mathrm{I}$ it may be assumed that not a great deal was expected of him. He nevertheless finished third to the late Colonel Harry M'Calmont's Devil-May-Care. Another colt belonging to Colonel $\mathrm{M}$ 'Calmont-Cushendall-beat him out of a place at his next attempt, in the Windsor Castle Stakes at Ascot, and he just missed a place for the Lavant Stakes at Goodwood, behind the dead-heaters, Lord Houghton's Flitters-the then Lord Houghton, at present known as the Marquess of Crewe-and the Duke of Westminster's Omladina. It was hardly to be supposed that Bay 


\section{GALICIA : HER FORBEARS}

Ronald could have a chance for the Middle Park Plate, which went that year to Mr. Leopold de Rothschild's St. Frusquin, who beat Omladina by half a length, the favourite, H.R.H. the Prince of Wales' Persimmon, five lengths away, third; and St. Frusquin found little difficulty in giving Bay Ronald ro 1b. in the Dewhurst Plate, $\mathrm{Mr}$. Leonard Brassey's colt finishing indeed last of the five.

It will be seen that big things had been asked of the colt, and so it continued next season. The ground was very hard in the spring of 1896 , and for that reason $\mathrm{Mr}$. Leopold de Rothschild did not bring out St. Frusquin for the Newmarket Stakes, he having already won the Column Produce Stakes and the Two Thousand. Galeazzo did duty for him, and shared favouritism with the Duke of Westminster's Labrador at 9 to 2, 5 to $\mathrm{I}$ being laid against the Duke of Devonshire's Balsamo, after whom in the market came Bay Ronald, roo to I5. There were fifteen starters, and the fact of Bay Ronald being backed at this comparatively short price is evidence that he had wintered well. He ran, moreover, far from badly. Galeazzo had a neck the better of Balsamo, Bradwardine third, beaten three lengths, Bay Ronald fourth, in front of Labrador. There was some promise about this, but the colt continued $4^{2}$ 


\section{AND HER OFFSPRING}

to $\mathrm{fly}$ at the highest game, and next came out for the Derby, finishing fifth to Persimmon, who, as every one with any acquaintance with racing affairs is aware, beat St. Frusquin by a neck.

Epsom, I 896.

The One Hundred and Seventeenth Renewal of the DERBY STAKES of 6000 sovs., by subscription of 50 sovs. each, h. ft. of 5 sovs, if declared, with 165 sovs. added; for three-year-olds; colts 9 st., and fillies 8 st. $9 \mathrm{lb}$. The nominator of the winner received 500 sovs., the owner of the second 300 sovs., and the owner of the third 200 sovs. Out of the stakes. About one mile and a half. (276 subs., 67 of whom paid 5 sovs. each $-£ 5450$.)

H.R.H. the Prince of Wales' b. c. Persimmon, by St. Simon . . . J. Watts I

Mr. Leopold de Rothschild's br. c. St. Frusquin . . . . T. Loates 2

Mr. H. C. Beddington's br. c. Earwig . Allsopp 3 Mr. B. S. Straus' br. c. Teufel . . F. Pratt 4 Mr. L. Brassey's b. c. Bay Ronald . . Bradford 5 Mr. Leopold de Rothschild's b. c. Gulistan Calder o Mr. L. Brassey's b. c. Tamarind . . Grimshaw o Mr. A. Calvert's br. c. Bradwardine . Rickaby O Mr. J. Wallace's b. c. Spook . . . Colling o Mr. E. Cassel's b. c. Toussaint . . Woodburn o Mr. H. M'Calmont's b. c. Knight of the Thistle

M. Cannon o Mr. Rothschild declared to win with St. Frusquin.

Betting. - I 3 to 8 on St. Frusquin, 5 to $I$ against Persimmon, 100 to 9 Teufel, 25 to I each Bay Ronald and Knight of the Thistle, 33 to I each Gulistan and Ear- 


\section{GALICIA : HER FORBEARS}

wig, 40 to I Bradwardine, IOO to I each Spook and Toussaint, and I 000 to I Tamarind. Won by a neck; four lengths between second and third.

There is a proverb about knowing a man by the company he keeps, and to some extent horses may be judged after the same fashion. Bay Ronald at least kept excellent company, and if he did not always shine in it, peculiar brilliance is necessary in order to obtain distinction among the highest class. It is not impossible that there have been years when Bay Ronald might have made at any rate what is called "a bold bid" for the Derby if he had not actually won it. Supposing he had been one year older it is far from certain that Sir Visto would have beaten him, and had he been two years younger, which would have made him a three-year-old in 1898 , he might quite possibly have beaten Jeddah. That at least is the estimate I form of him, though of course one cannot speak with any approach to confidence about the relative merit of horses who never came into opposition.

After Epsom Bay Ronald went to Ascot, and ran for the race which is called the Derby at that Meeting. There were only four starters, two of them on offer at odds of 20 to $r$, indeed the race was evidently looked on as a good thing for the Duke of Westminster's Conroy, a son of Bend Or 


\section{AND HER OFFSPRING}

and Grace Conroy, for odds of 9 to 4 were laid on him-Bay Ronald, nevertheless, being quoted at 5 to 2. Conroy won, Bay Ronald beaten for second place three parts of a length by $\mathrm{Mr}$. J. H. Houldsworth's Positano, and it may be assumed that the jockeys rode out for places, as in this race the second receives $£ 200$, the third $£$ Ioo. This was not Bay Ronald at his best, at the same time something must have been thought of the performance, for on the Friday we find him second favourite at 7 to 2 for the Hardwicke Stakes. The absolute favourite was another colt from Kingsclere, a stable companion of Conroy, the Duke of Portland's Shaddock, I I to 8 , and he won, Bay Ronald, though Shaddock was giving him 12 lb., finishing no nearer than fifth.

That race, it must freely be confessed, shows the horse in an unflattering light, but I have an idea that he was not seen in his true colours at this Ascot Meeting. At his next attempt he was engaged on a task which he could not be expected to fulfil. He was brought out for the Jockey Club Stakes at the Newmarket First October Meeting. At one time it had been supposed that Persimmon and St. Frusquin, unless the Leger had shown that one was unquestionably better than the other-a point which 


\section{GALICIA : HER FORBEARS}

the Derby and the Princess of Wales's Stakes had left doubtful-would have met once more for this rich prize. St. Frusquin, however, had finally disappeared from active service on the race-course after winning the Eclipse Stakes. There was an idea that the late Colonel Harry M'Calmont's Knight of the Thistle, who was receiving $17 \mathrm{lb}$. from Persimmon, had some sort of chance, and the Duke of Westminster's Regret was considered to be not altogether hopeless, Ioo to 12 being his price. Persimmon, however, i i to 8 on, won by a couple of lengths from Sir Visto, Laveno filling the third place four lengths away. Some long prices were on offer, though there were only ten runners. Laveno and Utica stood at 66 to I, Bay Ronald and The Lombard at 100 to I, and 300 to I was to be had, at least according to the return, against a filly called Bride of the Sea, and also against Kirkconnel, notwithstanding that he had won the Two Thousand Guineas the previous year.

At length, however, Bay Ronald was to come to the front. He ran for the Lowther Stakes at the Second October Meeting with the following result :

Newmarket, I 896 .

The Lowther Stakes of 20 sovs. each for starters, with 500 sovs. added; for three-year-olds and upwards; 46 


\section{AND HER OFFSPRING}

second received 50 sovs. out of the stakes and third saved his stake; entrance Io sovs. A.F. (28 entries- $£ 500$.)

Mr. L. Brassey's Bay Ronald, by Hampton, 3 yrs., 7st. 9 lb. . . . . Finlay I

Lord Rosebery's Avilion, 3 yrs., 8st. 3 lb. S. Loates 2 Duke of Westminster's Rampion, 3 yrs., S st. I Ib. . . . . . Calder 3 Mr. Leopold de Rothschild's Utica, 4 yrs., 9 st. 2 lb. . . . M. Cannon o Mr. H. E. Beddington's Earwig, 3 yrs., $S$ st. I lb. . . . . . Allsopp 0

Betting.-I 3 to 8 against Earwig, 7 to 4 Rampion, 8 to I Bay Ronald, I oo to I 2 Utica, and Io to I Avilion. Won by three lengths; four lengths between second and third.

Earwig had been third to Persimmon and St. Frusquin at Epsom, beaten four lengths, as previously noted Bay Ronald was fifth, and here Earwig was trying to give him $6 \mathrm{lb}$. If not a great performance it was at any rate a creditable one, and next time it may be said that he did better.

Newmarket, I 896.

The Limekiln Stakes of 50 sovs. each for starters, with I 000 sovs. added ; for three-year-olds and upwards; second received I 50 sovs. out of the stakes and third saved his stake; entrance, I 5 sovs. R.M. (39 entries- - I 085.)

Mr. L. Brassey's Bay Ronald, by Hampton, 3 yrs., $S$ st. 7 lb. .

Bradford I 


\section{GALICIA : HER FORBEARS}

Lord Rosebery's Avilion, 3 yrs., 8 st. 3 lb. . . . . .

Duke of Devonshire's Balsamo, 3 yrs., 8 st. 7 lb. :

Mr. H. M'Calmont's Knight of the Thistle, 3 yrs., 7 st. 9 lb. . . .

Mr. Leopold de Rothschild's Utica, 4 yrs.,
9 st. 2 lb.
T. Loates o

Mr. J. H. Houldsworth's Laveno, 4 yrs.,

9 st. $8 \mathrm{lb}$. . . . .

S. Loates 2

Madden 3

Allsopp o

F. C. Pratt o

Duke of Westminster's Regret, 3 yrs.,

8 st. I 2 lb. . . . M. Cannon O

Betting. -5 to 4 against Regret, 4 to I Balsamo, 8 to I Knight of the Thistle, I oo to I 2 Avilion, Io to I Bay Ronald and Laveno, and IOo to 8 Utica. Won by a length; three lengths between second and third.

Regret was always a disappointing animal. That Bay Ronald had made a highly favourable impression was proved by the fact of his starting favourite for the Free Handicap for Three-YearOlds, a race which dropped out of the Calendar about I9r2, though what may be called the companion stake for two-year-olds still continues.

Newmarket, I 896 .

A Free Handicap Sweepstakes of ioo sovs. each, h. $\mathrm{ft}$. ; for three-year-olds; winners extra; second received 200 sovs. out of the stakes, and third saved his stake. A.F. (22 subs._£ I050.)

Mr. Leopold de Rothschild's Gulistan, by Brag, 9 st. . . . . . T. Loates I 48 


\section{AND HER OFFSPRING}

H.R.H. the Prince of Wales's Thais, 8 st.

Io lb. . . . . M. Cannon 2

Prince Soltykoff's South Australian, 8 st. Toon 3

Mr. L. Brassey's Bay Ronald, 8 st. 5 lb.

(inc. 5 lb. ex.) . . . . Bradford 0

Lord Ellesmere's Miss Fraser, 8 st. 2 lb. Finlay 0

Mr. J. Wallace's Spook, 8 st. . . . Allsopp o

Mr. Hamar Bass's ch. f. by Marden-

Abeyance, 7st. $8 \mathrm{lb}$. . . Fearis 0

Betting.-I I to 4 against Bay Ronald, 3 to I Spook, 9 to 2 Thais, I I to 2 Gulistan, 10 to I each Miss Fraser and South Australian, and 100 to 6 the Abeyance filly. Won by three-quarters of a length; same between second and third.

The two races which Bay Ronald won were worth $£ 1585$.

Throughout his career Bay Ronald was destined to meet the Duke of Devonshire's Balsamo on several occasions. Both had started for the Middle Park Plate, the only occasion on which the son of Friar's Balsam and Snood was seen as a two-year-old. As will be noted, they had come together in the Limekiln Stakes; in the Newmarket Stakes, when Balsamo was second, beaten a neck by Galeazzo, Bay Ronald fourth, some four lengths behind; and they met again in the City and Suburban of 1897 , with which the fouryear-old labours of both of them began. The Limekiln Stakes had seemed to settle the question 


\section{GALICIA : HER FORBEARS}

between the two, though it was contradictory of some earlier form taken through Shaddock. This last named was a fairly good colt. As a three-year-old he had won six of his eight races, worth $£ 5^{8} 5^{2}$, but in the Hardwicke Stakes, as already set forth, he had shown great superiority to Bay Ronald, whereas in the Prince of Wales's Stakes at Ascot, Balsamo, in receipt of only I $1 \mathrm{~b}$. from Shaddock, had run the Duke's horse to a neck. Nevertheless Balsamo was distinctly preferred for the Epsom Spring Handicap.

Epsom, I 897.

The City and Suburban Handicap of 2000 sovs., by subscription of 35 sovs. each, $20 \mathrm{ft}$., or 5 sovs. if declared, with 805 sovs. added; second received 200 sovs. and third 100 sovs. out of the race. About one mile and a quarter. (62 subs., 18 of whom paid 5 sovs. each-£I 665 .)

Duke of Devonshire's Balsamo, by Friar's

Balsam, 4 yrs., 7 st. 4 lb. . . O. Madden I

Mr. L. Brassey's Bay Ronald, 4 yrs.,

7 st. 7 lb. . . . Allsopp 2

Sir J. Miller's La Sagesse, 5 yrs., 7 st.

I $2 \mathrm{lb}$. . . . . S. Loates 3

Baron de Rothschild's Amandier, aged,

8 st. 2 lb.

C. Wood o

Lord Ellesmere's Villiers, 5 yrs., 7 st. . S. Chandley o

Lord Rosebery's Quarrel, 6 yrs., 8 st.

I 2 lb. (car. 8 st. I 3 lb.) . . J. Wätts O

Mr. P. Lorillard's Diakka, 4 yrs., 7 st.

I $2 \mathrm{lb}$ (car. 7 st. I $3 \mathrm{lb}$.) . . Bradford 0 


\section{AND HER OFFSPRING}

Mr. Richard Croker's Santa Anita, 6 yrs., 7 st. I 2 lb. . . . J. Woodburn o

Mr. B. I. Barnato's Stowmarket, 6 yrs., 7 st. Io lb. . . .

Mr. Theobald's Phœbus Apollo, 4 yrs., 7 st. 2 lb. . 7 T. Simpson Jay's Rampion, 4 yrs.

7 st. 2 lb. . . . . K. Cannon o

Prince Soltykoff's South Australian, 4 yrs., 6 st. I 3 lb. . . . Robinson o Mr. Straus' Teufel, 4 yrs., 6 st. I 2 lb. . Toon o Lord Derby's Crestfallen, 3 yrs., 6 st. Io lb. (car. 6 st. I I lb.) . . J. Sharples o Mr. C. D. Rose's Melfitana, 3 yrs., 6 st.

7 lb. (car. 6 st. 9 lb.). . . Fearie

o

Betting.-9 to 2 against Balsamo, IOo to 15 Stowmarket, 9 to I Teufel, I oo to I I Bay Ronald, I oo to 9 each South Australian and Quarrel, roo to 8 Crestfallen, I 00 to 7 Melfitana, I 00 to 6 Amandier, 20 to I Diakka, 28 to I Villiers, 33 to I Rampion, 40 to I La Sagesse, 50 to I each Santa Anita and Phœbus Apollo. Won by half a length; three lengths between second and third. Amandier and Villiers ran a dead heat for fourth place, beaten a short head.

The first and second thus came out as nearly as possible the same horse, and the running was certainly meritorious. La Sagesse, after winning the Oaks, had afforded evidence of continued wellbeing by winning the Derby Cup as a four-yearold, after just missing the Newmarket October Handicap, giving $29 \mathrm{lb}$. to the winner-a threeyear-old, however-and failing by only half a 


\section{GALICIA : HER FORBEARS}

length. Bay Ronald was next seen at Ascot, and in an important race which, it will be perceived, he was confidently expected to take.

Ascot, I 897 .

The Hardwicke Stakes of IO sovs. each, with 2000 sovs. added; for three-year-olds and upwards ; second received Io per cent. and third 5 per cent. of the whole stake. Swinley Course. (6I subs.$£ 2378$, I Os.)

Mr. L. Brassey's Bay Ronald, by Hampton, 4 yrs., 9 st. 7 lb. . . . Bradford I

Lord Cadogan's Lowly, 3 yrs., 7 st. 4 lb. . Robinson 2 Mr. Hamar Bass's b. c. by St. SerfNovitiate, 3 yrs., 7 st. $7 \mathrm{lb}$. . . F. Finlay 3 Duke of Devonshire's Minstrel, 3 yrs., 8 st.

$8 \mathrm{lb}$. . . . . M.Cannon 4 Mr. C. D. Rose's Frisson, 3 yrs., 7 st. I 2 lb. S. Loates o Lord Rosebery's Trawler, 3 yrs., 7 st. 7 lb. Allsopp O

Betting.-I I to Io against Bay Ronald, 4 to I each the Novitiate colt and Minstrel, Io to I each Lowly and Trawler. Won by two lengths; six lengths between second and third.

It may be said the opposition was not strong, for though Minstrel had won the Ascot Derby he had only been opposed by one very poor filly. After this Bay Ronald flew at high game.

Tenth Renewal of the Eclipse Stakes of $£_{9285}$. Eclipse Stakes Course. One mile and a quarter.

H.R.H. the Prince of Wales's Persimmon,

4 yrs., Io st. 2 lb. . . . J. Watts I 


\section{AND HER OFFSPRING}

Lord Rosebery's Velasquez, 3 yrs., 9 st.

$4 \mathrm{lb}$. . . . . C. Wood 2

Mr. Leonard Brassey's Bay Ronald, 4 yrs.,

9 st. 13 lb. . . . . . Bradford 3

Mr. A. F. Calvert's Bradwardine, 4 yrs.,

9 st. 6lb. . . . . . T. Loates 4

M. Ephrussi's Beato, 4 yrs., 9 st. 10 lb. . T. Lane 5

Betting.- 100 to 12 on Persimmon, 100 to 8 against Velasquez, 25 to I Bay Ronald, 33 to I Bradwardine, 40 to I Beato. Won by two lengths; four lengths second and third. Time, 2 mins. $9 \frac{3}{5}$ secs.

The race came out, it will be noted, precisely in accordance with anticipation, Bay Ronald doing neither better nor worse than it seemed likely he would do. In the Champion Stakes at the Newmarket Second October Meeting he again encountered Velasquez. At Sandown he had been trying to give $9 \mathrm{lb}$. and had been beaten four lengths. At Newmarket, 2 to I being laid on Velasquez, Lord Rosebery's colt beat him by a couple of lengths, which might have been extended to four had there been any object. Though constantly set tasks which he could not possibly accomplish his reputation suffered little, and by the time the Cambridgeshire Handicap was made it was supposed that a considerable margin separated him from his old antagonist Balsamo, for Bay Ronald carried 8 st. $6 \mathrm{lb}$., the Duke of Devonshire's colt 7 st. ro lb. Neither had any- 


\section{GALICIA : HER FORBEARS}

thing to do with the finish, which was a question of heads between Comfrey, St. Cloud II, Sandia, and Cortegar. He was out once more as a fouryear-old for the Liverpool Autumn Cup, not fancied, with 8 st. 3 lb., as the odds of 25 to I against him make plain.

Liverpool, I 897.

The Liverpool Autumx Cup (handicap) of I 200 sovs. by subscription of 25 sovs. each, I $5 \mathrm{ft}$., or 5 sovs. if declared, with 595 sovs. added; second received 70 sovs. and third 50 sovs. out of the race. Cup Course, one mile and three furlongs. (53 subs., 34 of whom paid 5 sovs. each-£1075.)

Lord Stanley's Chiselhampton, by Hampton, 4 yrs., 8 st. I lb. . S. Loates I Capt. Bewicke's General Peace, 3 yrs., 6 st. I $2 \mathrm{lb}$. . . . N. Robinson 2

Duke of Westminster's Labrador, 4 yrs.,

8 st. 5 lb. (car. 8 st. 6 lb.) . M. Cannon 3

Lord W. Beresford's Nunsuch, 3 yrs.,

7 st. $8 \mathrm{lb}$. . . . . O. Madden 4

Mr. Dobell's The Rush, 5 yrs., 9 st. . J. Watts - o

Mr. A. Cohen's Greenlawn, 6 yrs., 8 st. $6 \mathrm{lb}$. . . . Bradford o

Mr. L. Brassey's Bay Ronald, 4 yrs., 8 st. $3 \mathrm{lb}$. . . . .

Mr. A. F. Calvert's Bradwardine, 4 yrs., 8 st.

F. Finlay $\quad 0$

C. Wood 0

Mr. Leopold de Rothschild's Jaquemart, 3 yrs., 7 st. $6 \mathrm{lb} . \quad \cdot \quad \cdot 7$

Col. Paget's Waterhen, 3 yrs., 7 st. $6 \mathrm{lb}$.

T. Loates 0

T. Fiely 0 


\section{AND HER OFFSPRING}

Mr. Jersey's Maluma, 5 yrs., 7 st. 4 lb. J. Sharples O Mr. J. Bibby's Chin Chin, 6 yrs., 7 st.

4 lb. . . . . Allsopp o

Mr. H. C. White's Form, 5 yrs., 7 st.

3 lb. . . . . . Sloan o

Mr. Dobell's Sligo, 3 yrs., 7 st. 3 lb. . S. Chandley o Mr. F. C. G. Menzies' Laughing Girl,

3 yrs., 7 st. I lb. (car. 7 st. 3 lb.) K. Cannon o

Betting. -9 to 2 against General Peace, 5 to I Labrador, I 00 to I 4 each Greenlawn and Nunsuch, I 00 to I 2 The Rush, I 0 to I Bradwardine, I oo to 8 Chiselhampton, I 00 to 6 Jaquemart, 20 to $\mathrm{I}$ each Waterhen, Maluma, and Sligo, 25 to I Bay Ronald, 40 to I Form, and 50 to I Laughing Girl. Won by a head; two lengths between second and third.

As a five-year-old in 1898 Bay Ronald led off by winning the race with which his name is chiefly associated, the City and Suburban.

Epsom, I 898.

The City and Suburban Handicap of 2000 sovs. by subscription of 35 sovs. each, $20 \mathrm{ft}$. or 5 sovs. if declared, with 970 sovs. added; second received 200 sovs. and the third IoO sovs. out of the race. About one mile and a quarter. (50 subs., 16 of whom paid 5 sovs. each-£ I 665.)

Mr. L. Brassey's Bay Ronald, by Hampton, 5 yrs., 7 st. I 2 lb. (car. 8 st.) . . . . Bradford I

Mr. W. Cooper's Newhaven II, 5 yrs.,

8 st. 8 lb. . . . . Rickaby 2

Mr. F. R. Hunt, jun.'s, Craftsman, 3 yrs., 6 st. 2 lb. . . . C. Purkis 3 


\section{GALICIA : HER FORBEARS}

Mr. H. M'Calmont's Knight of the Thistle, 5 yrs., 8 st. 6 lb. . . M. Cannon 4 Captain Greer's Kilcock, 6 yrs., 9 st. $4 \mathrm{lb}$. . . . . Mr. P. Lorillard's Sandia, 4 yrs., 8 st. $4 \mathrm{lb}$. . . . . S. Loates . 0 Mr. Fairie's Eager, 4 yrs., 8 st. 4 lb. . Allsopp O Lord Stanley's Chiselhampton, 5 yrs., 8 st. 2 lb.

J. Watts 0

Rosebery's Chelàndry, 4 yrs., 8 st. . . . . Mr. J. R. Keene's St. Cloud II, 4 yrs., 7 st. I 3 lb.. .. H.R.H. The Prince of Wales' Nunsuch, 4 yrs., 7 st. 6 lb. . . Mr. H. T. Barclay's Ashburn, 4 yrs., 7 st. 4 lb. (car. 7 st. 5 lb.) . Mr. Theobalds' Phœbus Apollo, 5 yrs., Mr. C. D. Rose's Melfitana, 4 yrs., 7 st. . . . . . Mr. Jersey's Brayhead, 4 yrs., 6 st. Io lb. (car. 6 st. I 3 lb.) . Mr. T. Cannon's Amphidemas, aged,
6 st. I $2 \mathrm{lb}$. T. Dunn o

Segrott

o

R. Jones o H. Toon o Mr. H. C. White's Form, 6 yrs., 6 st.

I 2 lb. . . . . Lord Ellesmere's Fortalice, 4 yrs., 6 st.

I I lb. • • • • • H. Jones

Betting. - 8 to I each against Kilcock and Knight of the Thistle, 100 to I 2 each Sandia and Bay Ronald, 9 to I each Eager and Nunsuch, IoO to 6 each Chelàndry, Newhaven II, and St. Cloud II, 20 to I each Amphidamas and Fortalice, 25 to I each Brayhead and Crafts56 


\section{AND HER OFFSPRING}

man, 40 to I each Ashburn, Phœbus Apollo, and Melfitana, 50 to I Chiselhampton, and 100 to I Form. Won by two lengths; a head between second and third.

Kilcock, the favourite, was, it will be seen, endeavouring to give Bay Ronald $20 \mathrm{lb}$. Knight of the Thistle was a horse whose name has occurred several times in previous pages. The difference between $I 00$ to $I 2$ and $S$ to $I$ is so small that Bay Ronald may be described as having practically started favourite, with Eager hardly less in demand. Bay Ronald, as already noted, had shown his liking for the course twelve months previously, and he won in good style from Newhaven II, who was imported from Australia by the present Sir William Cooper. This horse was destined to follow Bay Ronald's example, for he won, carrying 9 st., the following season, as $\mathrm{Mr}$. Leonard Brassey's horse had done after being second at his first essay on the course. In the Epsom Cup, then run over the Derby course as the Coronation Cup is at present, Bay Ronald showed that there was certainly no mistake about hit victory at the Spring Meeting.

\section{Epsom, I 898.}

The Epsom Cup of 500 sovs. (a Cup value roo sovs. and the remainder in specie) added to a Sweepstakes of 20 sovs. each, or 5 sovs. if declared; second received 50 sovs. out of the stakes. The Derby Course, about 


\section{GALICIA : HER FORBEARS}

one mile and a half. (20 subs., one of whom paid 5 sovs. - $£ 8$ I 5.$)$

Mr. L. Brassey's Bay Ronald, by Hampton, 5 yrs., 9 st. $6 \mathrm{lb}$. . Bradford I Mr. William Cooper's Newhaven II, 5 yrs., 9 st. $6 \mathrm{lb} . \quad$. . . Rickaby 2 Mr. J. C. Sullivan's Winkfield's Pride,

5 yrs., 9 st. 6 lb. . . . Mr. Jersey's Merman, 6 yrs., 8 st. Io lb. J. Watts 3 Mr. Douglas Baird's Champ de Mars,
3 yrs., 8 st.

C. Wood o

Belting.-I I to Io on Winkfield's Pride, 2 to I against Newhaven II, and Io to I each Champ de Mars and Bay Ronald. Won by two lengths; four lengths between second and third.

This was indeed doubtless his best performance, obviously better than in the Handicap, as here he was meeting Newhaven II at even weights instead of receiving $8 \mathrm{lb}$, as he had done five weeks previously. Here, too, was Winkfield's Pride, beating whom was certainly an achievement, for he was really a good horse. He had run second to Persimmon for the Ascot Cup; and, though very easily beaten, readily defeated in turn Mr. Hamar Bass's Love Wisely, and Limasol who had beaten Chelàndry and others, including Goletta, in the Oaks. Among the runners for this last-named race was Galatia, a daughter of Galopin and Pamela, not of course to be confused with Galicia, who gives the title 58 


\section{AND HER OFFSPRING}

to this book. Winkfield's Pride, besides winning the Lincolnshire Handicap with 8 st. 9 lb., had carried off the valuable Prix du Conseil Municipal in Paris in what was certainly a representative field, and the result was fully anticipated, moreover, as only 5 to 4 was laid against him, 5 to I against Omnium II and Masque, Io to I against Elf, the three last-named having been considered good enough to send to England for the Gold Cup. A winner of the great Ascot race, Merman, was also in the Epsom Cup, in receipt, moreover, of io $\mathrm{lb}$. from the three placed horses. After Epsom it is evident that Bay Ronald made excellent progress, the betting for the coveted Ascot trophy furnishing proof.

I have just been talking about the slight difference between 8 to $\mathrm{I}$ and $\mathrm{IOO}$ to $\mathrm{I} 2$; that between roo to 30 and 7 to 2 is still less, a detail suggested by the betting on the Ascot Cup.

Ascot, 1898.

The Gold CUp, value 1000 sovs., with 3000 sovs. in specie (of which the second received 700 sovs. and the third 300 sovs.), added to a Sweepstakes of 20 sovs. each, h. ft. ; three-year-olds, 7 st. 7 lb. ; four, 9 st. ; five, six, and aged, 9 st. 4 lb.; m. and g. allowed $3 \mathrm{lb}$. Starting at the Cup Post and going once round, about two miles and a half. (29 subs. $-£_{3350}$.)

Mr. J. de Bremond's ch. h. Elf II, by Upas, 5 yrs. . . . . E. Watkins I 


\section{GALICIA : HER FORBEARS}

Mr. Dobell's ch. h. The Rush, 6 yrs. . O. Madden 2 Mr. P. Torterolo's ch. h. Cartouche III, aged . . . . J. Torterolo 3

Sir S. Scott's b. or br. c. History, 4 yrs. M. Cannon 4 Mr. L. Brassey's b. h. Bay Ronald, 5 yrs. Bradford o M. E. Blanc's b. c. Masque II, 4 yrs. . Barlen O M. E. Blanc's ch. c. Montégut, 4 yrs. . T. Lane o M. E. Blanc's b. c. Longbow, 4 yrs. - C. Grey o Betting.- I 100 to 30 each against The Rush and Masque II, 7 to 2 each Elf II and Bay Ronald, and 100 to 6 History. Won by a length and a half; a bad third.

Bay Ronald cannot be said to have run well. The Rush, though he had won the Gold Vase, beating Newhaven II, who was third, by half a dozen lengths, was generally rated as a mere handicap horse, and much the same may be said of Sir Samuel Scott's History. It will be observed how vigorous was the French attempt on the Cup this year, four of the eight starters having come from across the Channel, Longbow one of them in spite of his English name. He was a son of The Bard and a mare called Old Bow.

The Epsom Cup was to be Bay Ronald's last victory. He tried again for the Hardwicke Stakes, which, as noted, he had taken the previous season.

Ascot, 1898 .

The Hardwicke Stakes of io sovs. each, with 2000 sovs. added; second received 10 per cent. and third 5 per 


\section{AND HER OFFSPRING}

cent. of the whole stake. Swinley Course. (65 subs. -£2242, IOs.)

Duke of Westminster's Collar, by St.

Simon, 3 yrs., 7 st. I 2 lb. . . O. Madden I

Mr. L. Brassey's Bay Ronald, 5 yrs.,

9 st. I 2 lb. . . . . Bradford 2

Mr. C. D. Rose's Cortegar, 4 yrs., 9 st.

$7 \mathrm{lb} . \quad$. . . . Soates 3

Sir J. Blundell Maple's Devon, 3 yrs.,

7 st. I 2 lb. . . . . C. Wood 4

Mr. L. Brassey's Merry Buck, 3 yrs.,

7 st. 12 lb. . . . . T. Loates 0 Mr. Russel's Nenuphar, 3 yrs., 7 st. I 2 lb. Toon o Sir M. FitzGerald's Sweet Hampton, 3 yrs., 7 st. 4 lb. (car. 7 st. 5 lb.) . N. Robinson o (Mr. Brassey declared to win with Bay Ronald.)

Betting.- I 5 to 8 against Collar, 9 to 4 Bay Ronald, I I to 2 Devon, I 00 to I 2 Cortegar, and Io to I any other. Won by three lengths; a length and a half between second and third.

Weight for age over a mile and a half in June between a three-year-old and a five-year-old is $20 \mathrm{lb}$., and Bay Ronald was giving $28 \mathrm{lb}$., so that without that advantage it may be assumed he would have won. It was not expected that he would beat Lord Rosebery's Velasquez in the Champion Stakes. The two ran at evens, odds of I I to 4 on Lord Rosebery's colt, I I to 4 against Bay Ronald, 200 to I against the other runner, a colt called Goblin, who was a very bad third, Velasquez winning by a length. Bay 


\section{GALICIA : HER FORBEARS}

Ronald tried again in the Lowther Stakes two days later, but it may be that his previous race had done him no good. He was last of three behind Prince Soltykoff's Ninus and the Duke of Westminster's Batt. Ninus was very useful, however, and Batt, a half-brother to Flying Fox by Sheen, had won his two previous races, as also the Payne Stakes in the Spring, had run second for the Derby, beaten only three parts of a length by Mr. Larnach's Jeddah, and had also been second to Velasquez for the Eclipse Stakes. Mr. Leonard Brassey's horse was to make one final appearance. This was in the Jockey Club Cup.

Newmarket, I 898 .

The Jockey Club Cup of 300 sovs. (a Cup, value 130 sovs., and the remainder in specie), added to a Sweepstakes of 20 sovs. each, h. ft.; for three-year-olds 7 st. I 2 lb., four 8 st. I 2 lb., five 9 st. I lb., six and aged 9 st. 2 lb.; m. and g. allowed 3 lb. ; second received 50 sovs. out of the stakes. Cesarewitch Course. (I 5 subs.—£ 4 I 0 .)

Mr. Jersey's ch. h. Merman, by Grand Flâneur, 6 yrs. . . . . M. Cannon I Mr. Dobell's ch. h. The Rush, 6 yrs. . O. Madden 2 Mr. L. Brassey's b. h. Bay Ronald, 5 yrs. Bradford 3

Betting.-I I to Io against Merman, 7 to 4 The Rush, and 5 to I Bay Ronald. Won by four lengths; a bad third.

It may be presumed that Bay Ronald was not so good a stayer as the other two; indeed this 62 


\section{AND HER OFFSPRING}

may be accepted as beyond question, the Ascot Cup confirming it in the case of The Rush, and as for Merman, a comparison of this Jockey Club Cup with the Epsom Cup tells its own tale.

Bay Ronald retired to the Preston Stud Farm at Aylesford in Kent, and stood at a fee of 25 guineas in the year 1900. To sum up his performances, as a two-year-old he was out five times without success; as a three-year-old he won two stakes in eight attempts, of the value of $£{ }^{1} 5_{5}$; his solitary win as a four-year-old in six attempts yielded $£ 2378$, and his two five-year-old races produced $£ 2480$. Thus altogether Bay Ronald ran twenty-six times, winning five races

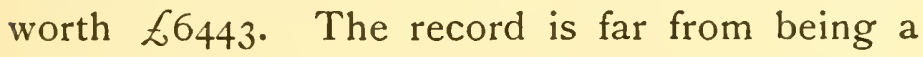
great one.

It is always particularly interesting to have an owner's account of his horse, and Major Leonard Brassey, though busily engaged on duty with the Northamptonshire Yeomanry at the time when I begged him to give me some account of his horse, most kindly sent the following sketch :

\section{BAY RONALD}

Bay Ronald by Hampton-Black Duchess was bred in 1893 by Mr. T. Phillips at the Leybourne Grange Stud, and was sent up for sale at Doncaster in 1894 with Mr. Phillips' other 63 
yearlings. I recollect my trainer, Tom Jennings, jun., writing to me shortly after the Doncaster Meeting to say that he had seen a nice yearling of Mr. Phillips' there which had failed to fetch the reserve price of 500 guineas. Tom Jennings suggested that as I lived close to Leybourne Grange I might like to go over and see the colt. This I did, with the result that Bay Ronald became my property.

I bought Black Duchess, the dam of Bay Ronald, at the sale at the Second October Meeting, I896, curiously enough but a few hours before Bay Ronald won his first race, the Lowther Stakes. About the same time I remember Mr. M. Gurry offering to sell me for $£ 200$ a half-sister to Bay Ronald, Black Cherry, by Bendigo-Black Duchess. This I declined, but Colonel W. Hall Walker-with better judgmentpurchased this mare, and she became the dam of Black Arrow, Cherry Lass (winner of the Oaks), Jean's Folly, and therefore the grand-dam of Night Hawk, winner of the St. Leger of I9I3. As a two-year-old Bay Ronald was not of much account, nor indeed did he "come to hand" before the latter part of his three-year-old career, when he won the Lowther Stakes and Limekiln Stakes at Newmarket. He began his four-year-old season by running second to Balsamo in the City and 64 


\section{AND HER OFFSPRING}

Suburban, giving $3 \mathrm{lb}$. I always look upon this as perhaps the most unlucky race of my Turf career. As after events proved, Bay Ronald was an exceptionally good horse on the Epsom Course. He was very well on the day, and he should certainly have beaten Balsamo. Bay Ronald subsequently won the Hardwicke Stakes at Ascot, but could only run third to Persimmon and Velasquez in the Eclipse Stakes, and second to Velasquez in the Champion Stakes at Newmarket.

As a five-year-old Bay Ronald won the City and Suburban and the Epsom Cup, beating Newhaven II and Winkfield's Pride. He was then trained for the Ascot Gold Cup, in which he ran unplaced. My action in this matter was scarcely judicious. The horse never showed ability to stay more than a mile and a half, and a severe preparation for the Cup, followed by the race on hard ground, in all probability had a permanently adverse effect. I think Bay Ronald' was never afterwards in the form he was when he so easily won the Epsom Cup.

On the day following the Gold Cup he ran second to Collar in the Hardwicke Stakes. After his struggle the previous day on very hard ground I do not think this can be taken as Bay Ronald's true form. Collar had won 65 


\section{GALICIA : HER FORBEARS}

the Trial Stakes on the first day of the Ascot Meeting, and John Porter sent the horse back to Kingsclere on the Wednesday, not intending to bring him out again at the Meeting. On the Thursday evening, realising that horses which had run for the Gold Cup would probably not be at their best on the following day, and that the remainder of the opposition was not likely to be strong, Porter telegraphed for Collar to be sent back to Ascot, with the result that he won the nice stake of $£ 2242$ for the Duke of Westminster.

There is little to relate of Bay Ronald's subsequent performances on the Turf, except that Tom Jennings-by no means one of the "Cocksure Brigade"-was rather confident that he would win the Goodwood Cup of that year. Owing to a family bereavement the day before the race I did not run him.

Though Bay Ronald achieved a fair amount of success on the racecourse one cannot describe him as having been quite a first-class racehorse. His form was certainly somewhat variable, this being accounted for, I think, by the fact that his constitution as a young horse was not of a very robust character, and strong preparations for longdistance races may have rather taken the steel out of him later on. 


\section{AND HER OFFSPRING}

Bay Ronald with very limited opportunities was a distinct success at the Stud. His most conspicuous sons are Bayardo, Dark Ronald, and Macdonald II, the latter a first-class racehorse and a most successful stallion in France.

One talks of "the glorious uncertainty" of the Turf. The glorious uncertainty of breeding racehorses is hardly less. At the December sales at Newmarket in 1897 I recollect that Prince Pierre d'Arenberg and the Comte de Pourtales came round Tom Jennings' stables one evening. The former had bought at the sales that day a mare called Marie, and was doubtful what he should do with her. I suggested that he might send her to Bay Ronald, who was just about to commence Stud duties. This was done, and Macdonald II was the result.

I sold Bay Ronald for $£_{5} 500$ to go to France, unfortunately before Bayardo and Dark Ronald appeared upon the scene. He did not, however, live long to bring profit to his new owners or further fame to himself, as he died in 1905. Bay Ronald grew into a beautiful and most bloodlike stallion, with a very perfect head and neck.

So Major Leonard Brassey most kindly wrote. To continue my own narrative, it was 


\section{GALICIA : HER FORBEARS}

not long before Bay Ronald began to make his mark at the Stud. In 1902 when his offspring first ran five of them won ten races worth $£_{3789}$, Rondeau securing five of these, and Arabi, a son of his owner's Merry Miser, taking the Great Foal Plate $(£ 835)$ at Lingfield, and the Astley Stakes $(£ 690)$ at Lewes, besides being placed in five of his other eight races. In the Bedford Stakes at the Newmarket Second July Arabi was second to Rock Sand, and on the occasion of his first appearance, in the Sandown Park Stud Produce Stakes, third to Our Lassie, who was to win the Oaks next year, and to Mr. Arthur James's good horse, Rabelais, who has been so brilliantly successful at the Stud in France. A result of all this was the increase of Bay Ronald's fee to Ioo guineas, and a note in the record states that he was full for 1904, Rondeau having continued to win in 1903, Merryman and Wild Oats also adding to his reputation; in all his five young ones won twelve races worth $£ 6$ igr. Merryman, who after a first appearance in the Brocklesby took three consecutive races worth $£ 2424$, was an own brother to Arabi. In 1904 there was no new horse of note among his seven winners (of twelve races worth $£_{3} 360$ ). Merryman was out three times without success, and in 1905 there was a drop, six horses winning ten races 68 



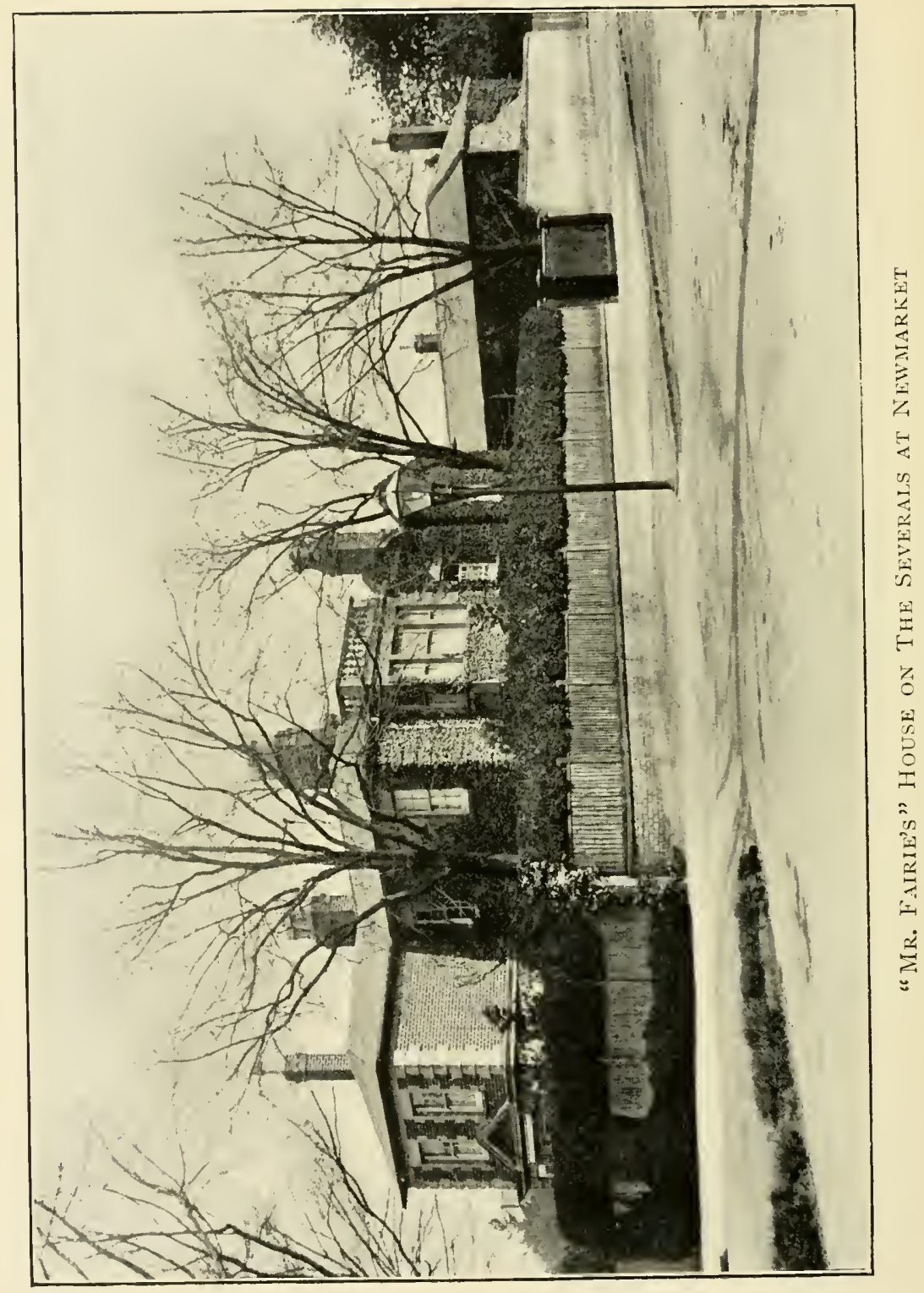




\section{AND HER OFFSPRING}

of small value, the whole amounting to only £i 556 .

Mr. Fairie, however, had determined to send Galicia to the horse in 1905, though he cannot have been much gratified with Bay Ronald's record for the season. Arabi won four little

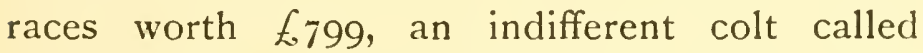
Galhampton just got home by a neck for a Plate worth $f_{2} 262$, and Ronaldo took a couple of minor stakes worth f220. Thus seven races worth $£ \mathrm{I} 28 \mathrm{I}$ was the total. In 1905 the fee had been reduced to 75 guineas. The year 1907 produced only Dark Ronald of any real note, though Rousay won thrice and was second in four of his other five races. Dark Ronald only appeared on two occasions, the first time successfully in the Hurst Park Foal Plate, which he won, though only by a head, from a colt called Quimpert, who was giving him $3 \mathrm{lb}$.; his second attempt was in the Great Foal Plate at Lingfield, when a remarkably speedy animal called Little Flutter, in receipt of $15 \mathrm{lb}$, beat him three lengths, odds of 6 to I being laid on the winner.

Bay Ronald was on the up grade; seven of his get won twelve races worth $£_{3} 660$; but there seemed no reason to assume that such brilliant distinction as that which he achieved was in store for him, that he was going to rise speedily to 


\section{GALICIA : HER FORBEARS}

eminence among sires; for owing to Bayardo he took his place at the end of the 1908 season third in the list, following Persimmon and St. Frusquin, in front of Gallinule, St. Simon, Chaleureuxwho, of course, owed his position to the amazing victories of Signorinetta-and Desmond. 



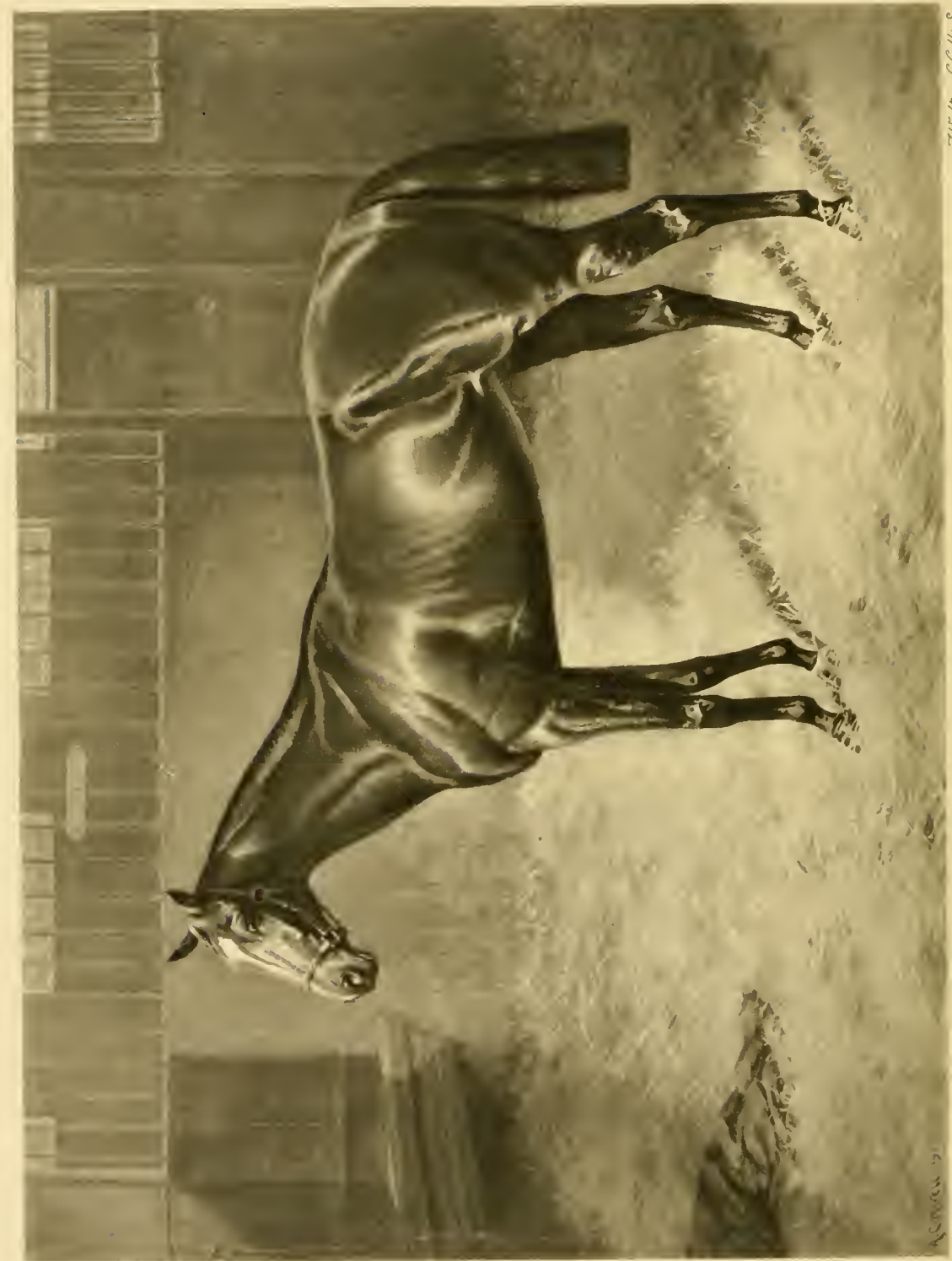




\section{AND HER OFFSPRING}

\section{CHAPTER III}

\section{BAYARDO}

A Number of good horses have made their first appearance in the New Stakes at Ascot, and Bayardo's name figures among them. His trial at Manton on the $9^{\text {th }}$ of June by no means strikes one as overwhelming. The distance was five furlongs.

Bayardo, 2 yrs., 8 st. 8 lb. . . . Madden I Seedcake, 3 yrs., 8 st. 8 lb. . . . Toon 2 Smuggler, 2 yrs., 7 st. I lb. . . . Hulse 3 Lady Vista, 2 yrs., 8 st. 5 lb. . . Broadwood o Highness, 2 yrs., 8 st. 5 lb. . . . Baker O

Won easily by six lengths; a length between second and third.

Of course, it was something to beat a threeyear-old at even weights; but Seedcake had run in half a dozen races prior to this gallop without ever having been placed, three as a two-year-old, three in 1908, and in the Trial Stakes with which this Ascot Meeting opened he was last. Probably he was a better horse at home than out.

Four others were preferred to Bayardo in the $7 \mathrm{I}$ 


\section{GALICIA : HER FORBEARS}

New Stakes, which is on the whole not strange. There was a strong favourite at 6 to 4 in $\mathrm{Mr}$. (as he then was) William Cooper's Perola, ridden by Maher. She had easily carried off the Woodcote Stakes at Epsom, fourth in which race had been a colt of Lord Rosebery's called Perdiccas. At Epsom Perdiccas had been giving Perola Io lb., he being penalised for two successes. In the New Stakes he had $7 \mathrm{lb}$. the better of the weights with the filly, and it was thought that so great a variation would change the result. Mr. J. B. Joel's Sunflower II was backed on the strength of private reputation. But the race was never in doubt.

Ascot, 1908.

New Stakes of $£_{\text {Io }}$ each, with $£_{\text {Iooo added, of which }}$ second received 10 per cent. and third 5 per cent.; for two-year-olds. Five furlongs. (I I 5 entriesEI 8 I 7 , IOS.)

Mr. Fairie's Bayardo, by Bay Ronald, 8 st. Io lb.

B. Dillon I

Lord Rosebery's Perdiccas, 8 st. $10 \mathrm{lb}$. W. Higgs 2 Mr. William C. Cooper's Perola, 9 st. Mr. E. Carlton's Corinnus, 8 st. io lb. Mr. J. B. Joel's Sunflower II, 8 st. Io lb. . . . . . Walter Griggs o Mr. H. J. King's Pernambuco, 8 st. Io $1 \mathrm{~b}$.

D. Maher 3

C. Leader 0

Mr. W. Raphael's Blankney II, 8 st. ro lb. . . . . H. Jones o 


\section{AND HER OFFSPRING}

Sir E. Cassel's Turban, 8 st. 7 lb. . W. Halsey o Sir Daniel Cooper's Vivid, 8 st. 7 lb. . L. Lyne o Mr. E. L. Heinemann's b. f. by St.

Maclou-Ramondia, 8 st. 7 lb. . W. Saxby O Mr. J. H. Houldsworth's Doro, 8 st. $7 \mathrm{lb}$.

Mr. W. M. G. Singer's b. f. by St.

Maclou-Great Dame, 8 st. 7 lb. W. Broadwood o Mr. W. Hall Walker's Blue Cap,

S st. $7 \mathrm{lb}$. . . . H. Randall O

Betting. -6 to 4 against Perola, 5 to I Perdiccas, 6 to I Sunflower II, 7 to I Bayardo, Io to I Doro, I oo to 8 Blankney II. Won by one and a half lengths; neck second and third.

Writing at the time under the signature "Rapier" in the Illustrated Sporting and Dramatic Nerus, my comment on the race was: "It soon became evident that Manton shelters the best colt of the season out so far," and there was no occasion to amend the last three words when the season was over. "Mr. Fairie has had some horses of high class," I continued, " and he tells me he thinks this undoubtedly the best he has ever owned."

There could not well have been a more promising start, and when Bayardo came out again for the National Breeders' Produce Stakes at Sandown, the most valuable two-year-old prize in existence, he was favourite as a matter of course. 


\section{GALICIA : HER FORBEARS}

Sandown, r 908.

National Breeders' Produce Stakes of $£ 5000$, of which nominator of winner received $£_{300}$, nominator and owner of second each $£ 200$, and nominator and owner of third each $£$ roo, by subscription of $£ \mathrm{I}$ each; if left in after January $\mathrm{r}$, 1907 , a further $£_{5}$; if left in after October 8,1907 , a further $£ \mathrm{r} 6$; and if left in after March 31,1908 , a further $£_{21}$; with $£_{437}$ added ; for two-year-olds. Five furlongs. (268 entrants, viz. 7 I at $£_{43}, 43$ at $£_{22}, 82$ at $£ 6$, and 72 at $£ \mathrm{I}-£_{4357 \text {.) }}$

Mr. Fairie's Bayardo, by Bay Ronald, 9 st. $2 \mathrm{lb}$.

D. Maher I

Lord Howard de Walden's ch. c. by

Gallinule-Excellenza, 9 st. I lb.

Sir Daniel Cooper's Vivid, 8 st. 7 lb. . W. Raphael's Louviers, 9 st. 5 lb. . Mr. C. Bower Ismay's Balnacoil, 9 st. 2 lb. Lord Rosebery's Perdiccas, 9 st. I lb. Mr. H. S. Goodson's Diospyros, 8 st. $10 \mathrm{lb}$. • $\cdot$.

Colonel H. T. Fenwick's Hamerton, 8 st. Io lb. .

Lord Michelham's William the Fourth, 8 st. $10 \mathrm{lb}$. H. Randall 2 L. Lyne 3 H. Jones $\mathrm{O}$ W. Saxby 0 W. Higgs 0 J. H. Martin O W. Halsey o Wm. Griggs o Mr. R. S. Sievier's The Jabberwock, 8 st. Io lb. . . . . Mr. J. B. Thorneycroft's Kilmein, 8 st. $7 \mathrm{lb}$

B. Dillon

o

Mr. Reid Walker's Dinnet, 8 st. 3 lb. F. Wootton o Lord Rosebery's 'Tantonie Bell, 8 st. . Mr. J. B. Joel's ch. c. by SundridgeSweet Story, 8 st. O. Madden 0 C. Trigg 0 Betting. -7 to 4 against Bayardo, 5 to I Excellenza c., 


\section{AND HER OFFSPRING}

Io to I Sweet Story c., I oo to 9 The Jabberwock, I oo to 8 Kilmein, 100 to 7 Perdiccas, 100 to 6 any other. Won by a length ; half a length second and third. Kilmein whipped round at the start and was left.

The unfortunate thing about this race was the reputation it earned for the second, Lord Howard de Walden's Excellenza colt, afterwards named Glasgerion ; for as Bayardo's fame grew so did opinion as to what might be accomplished by the animal who had run him to a length. That, however, is a matter which does not come into the present story. It is not by any means always that the best-looking horse is the best performer. Bayardo, however, was full of quality, and admiration for him steadily increased. There is a progression of stakes, as it may be called, in which one expects to find the very best two-year-olds, and the Richmond at Goodwood is one of them. Great names appear in the record of this eventJannette, Wheel of Fortune, Bend Or, Dutch Oven, Friar's Balsam, Orme, Persimmon, and others; and Bayardo won it at his leisure. No doubt was entertained of the result, but at the same time not a little was thought of Sir Daniel Cooper's Vivid, who, it will be seen, was receiving $\mathrm{I} 2 \mathrm{lb}$. more than sex allowance. 


\section{GALICIA : HER FORBEARS}

Goodwood, 1908.

Richmond Stakes of $£ 25$ each, ro ft. for acceptors, with

$£_{500}$ added, of which second received $£_{200}$ and third $£_{\mathrm{I} O 0}$; for two-year-olds. Entrance $£_{3}$, only ft. if declared. T.Y.C. Six furlongs. (73 entrants, ft. declared for $31-£ 652$.)

Mr. Fairie's Bayardo, by Bay Ronald, 9 st.

$8 \mathrm{lb}$.

Sir Daniel Cooper's Vivid, 8 st. 7 lb.

His Majesty's Oakmere, 8 st. Io lb.

Mr. J. Buchanan's Sister Betty, 8 st. 7 lb. W. Halsey

Betting.-3 to I on Bayardo, 4 to I against Vivid, 20 to I any other. Won by three lengths; two lengths second and third.

Bayardo's task at the Newmarket First October Meeting was of the simplest.

Newmarket, I 908.

Buckenham (post produce) Stakes of $£ 300$ each, h. ft.; for two-year-olds. T.Y.C. Five furlongs 134 yards. (I I subs. - $£$ I 500.)

Mr. Fairie's Bayardo, by Bay Ronald, 9 st. D. Maher I Mr. S. B. Joel's Bonnie Lassie, 8 st. I I lb. H. Randall 2 Duke of Portland's Vivario, 8 st. I I lb. . W. Earl 3

Betting.-2 5 to I on Bayardo. Won by three-quarters of a length; four lengths second and third.

Bonnie Lassie had been out half a dozen times without winning; Vivario, belonging to the Duke of Portland, a daughter of Ayrshire and Miss Gunning II, was sent from Kingsclere on an utterly hopeless errand. She was seen no 76 


\section{AND HER OFFSPRING}

more that year and only twice as a three-year-old, when it became unmistakably clear that it was useless to keep her in training. On the Friday of the Meeting Bayardo came out again for the Rous Memorial, opposed only by an animal called Auceps, who, though he had-unexpectedly - won a Maiden Plate on the first day of the Meeting, was very bad.

Newmarket, I 908.

Rous Memorial Stakes of $£$ I 5 each, i $O \mathrm{ft}$. for acceptors, with $£_{400}$ added for owner and $£_{\mathrm{I}}$ oo for nominator of winner; for two-year-olds; second received $£_{50}$ out of the stakes; entrance $£_{5}$, only $\mathrm{ft}$. if declared. Rous Course, 5 furlongs. (50 entrants, ft. declared for 2 I $-£ 730$.)

Mr. Fairie's Bayardo, by Bay Ronald, 9 st. D. Maher I Sir Daniel Cooper's Auceps, 8 st. 7 lb. . B. Lynham 2 Betting.-20 to I on Bayardo. Won by a length and a half.

There was never the slightest doubt about the odds of 20 to I laid on the son of Bay Ronald, and really no more doubt about the Middle Park Plate when that came on for decision.

Newmarket, I 908 .

Middle Park Plate of $£ 500$, added to a Sweepstakes of $£ 30$ each, $20 \mathrm{ft}$., of which second received $£ 200$ and third $£_{100 ;}$ for two-year-olds; entrance $£_{5}$; of the surplus, viz. $£_{75}$, second received two-thirds 


\section{GALICIA : HER FORBEARS}

and third the remainder. Bretby Stakes Course, 6 furlongs. (I I 5 entrants- $£ 2505$.)

Mr. Fairie's Bayardo, by Bay Ronald, 9 st. 3 lb. . . . . . D. Maher I Sir Daniel Cooper's Vivid, 9 st. . . O. Madden 2 Mr. W. Raphael's Blankney II, 9 st. . W. Higgs 3 Mr. L. Neumann's Shikaree, 8 st. Io lb. . B. Dillon o

Betting.-6 to I on Bayardo, Io to I against Vivid, I 00 to 6 Blankney II, IOO to I Shikaree. Won by a length; four lengths second and third.

I do not remember in the history of this race that there has ever been so hot a favourite, and there never was so small a field, though when one apparently invincible animal has gone to the post, there have on a couple of occasions been five starters : the number has extended to thirty, there having been nine-and-twenty behind Petrarch in I 875. The procession of notable races to which reference has been made includes the Dewhurst Plate, and this brought out Bayardo for the last time as a two-year-old.

Newmarket, 1908.

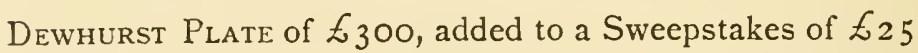
each, I $5 \mathrm{ft}$., of which second received $£ \mathrm{IOO}$; for two-year-olds; entrance $£_{3}$. Last 7 furlongs of R.M. (83 entrants- $£$ I 477.)

Mr. Fairie's Bayardo, by Bay Ronald, 9 st. 5 lb. . . . . . D. Maher I

Mr. William C. Cooper's Perola, 9 st. . O. Madden 2 


\section{AND HER OFFSPRING}

Mr. Arthur James's ch. c. by Persimmon -Lucina, 8 st. $9 \mathrm{lb}$. . . H. Jones 3 Mr. George Faber's Great Peter, $S$ st. $9 \mathrm{lb}$.

Mr. H. J. King's Carrousel, 8 st. 9 lb. . H. Randall o Mr. J. W. Larnach's Carbineer, 8 st. 9 lb. W. Saxby o

Betting. -75 to 20 on Bayardo, Io to I against Carrousel, I oo to 8 Perola. Won by three lengths; same second and third.

Thus he had run seven times and never been extended.

From the two-year-olds of 1908 it will be realised that Bayardo stood out, and as a matter of course he headed the Free Handicap for horses of his age. It naturally followed that he was a pronounced winter favourite for the Derby, and his position in this respect would have strengthened greatly but for the improvement which had taken place in King Edward's Minoru, not Sandringhambred, as his other classic winners, Persimmon and his younger brother Diamond Jubilee, had been, but a son of Cyllene and Mother Seigel leased from Colonel Hall Walker, and born at the Tully Stud in Ireland.

Minoru had been put in the Free Handicap at 7 st. $6 \mathrm{lb}$, in receipt of $22 \mathrm{lb}$. from Bayardo, and that he could have improved sufficiently to be a source of danger to Mr. Fairie's colt it was impossible to suppose prior to the time 


\section{GALICIA : HER FORBEARS}

when racing started in 1909. Minoru then went to Newbury to run for the Greenham Stakes, and he had done so well under the care of Richard Marsh at Egerton House that he was backed at 9 to 2, Lord Carnarvon's Valens a favourite on whom slight odds were laid, supported with more confidence as Minoru had to give him $5 \mathrm{lb}$. Visitors were, however, gratified by the spectacle of the success of the Royal colours. Minoru beat Valens a length and a half, and an idea sprung up that he might have an outside chance for the classics. This suggestion was chiefly advanced, however, by those who thought it would be a good thing for racing if the King won another Derby, particularly as no reigning King of England had done so in the history of the race. That Minoru could beat Bayardo few people seriously imagined, and when the Two Thousand came round odds of I 3 to 8 were laid on the son of Bay Ronald, 4 to I against Minoru. Bayardo was by no means at his best. Of that there could be no question. It was thought, nevertheless, that even when backward in condition he could at any rate beat the lot opposed to him. Indeed, with the exception of Minoru, as will be seen from the report of the race, no danger was apprehended. 



$$
5
$$




\section{AND HER OFFSPRING}

Newmarket, I 909.

Two Thousand Guneas Stakes of $£ \mathrm{I} O 0$ each, h. $\mathrm{ft}$., for entire colts and fillies foaled in 1906 ; colts 9 st., fillies 8 st. 9 lb.; second received $£_{400}$ and third $£ 200$ out of stakes. R.M. (I 93 entrants- $£ 5000$.)

His Majesty's br. c. Minoru, by Cyllene, 9 st.

Duke of Portland's b. c. Phaleron, 9 st. . Mr. W. Raphael's b. c. Louviers, 9 st. . H. Jones I Mr. Fairie's b. c. Bayardo, 9 st. . . Mr. J. Buchanan's b. c. Diamond Stud, 9 st. Mr. J. B. Thorneycroft's b. c. Grimmet, 9 st. . W. Earl 2 G. Stern 3 D. Maher 4 W. Halsey o Wm. Griggs o Mr. Leopold de Rothschild's b. c. Fop, 9 st. Mr. L. Neumann's b. c. Fidelio, 9 st. . Mr. Lionel Robinson's ch. c. Sealed Orders, 9 st. . . . . F. Wootton o Mr. Raphael's b. c. Blankney II, 9 st. . W. Higgs o Col. E. W. Baird's b. c. Orange Bud, 9 st. B. Lynham o

Betting.-I 3 to 8 on Bayardo, 4 to I against Minoru, 100 to 7 Louviers, 20 to I Diamond Stud, 25 to I Fop, Won by two lengths; a length and a half second and third.

Layers of odds knew their fate when the horses passed the Bushes, feeling convinced nevertheless that this could not be the real Bayardo. He ran without dash, and though his defeat was attributed to unreadiness a vague suspicion arose that he might not be the horse he had shown himself the previous season. This notion so far strengthened as time went on as to depose him from his position of favourite for SI 


\section{GALICIA : HER FORBEARS}

the Derby. Glowing accounts of the manner in which Minoru had been thriving came from Newmarket, and at the Turf headquarters another formidable rival had arisen in Mr. Louis Winans's Sir Martin, a son of Ogden and Lady Sterling, whom his owner had imported from the United States.

Sir Martin was trained by Joseph Cannon at Lordship Farm, and early in the year I had been down to have a look at him, to find a colt lacking in quality, but nevertheless striking one as a racehorse. He was introduced to the course in a Welter Handicap at the Newmarket Second Spring Meeting on the I th of May, exactly a fortnight before the Derby, and the class in this Handicap not being good, three-year-old as Sir Martin was, 9 st. Io lb. was put on his back, the lowest weight being 7 st. Dusky Slave, a four-year-old filly belonging to $\mathrm{Mr}$. J. B. Leigh, was favourite, carrying 7 st. 9 lb., and Sir Martin, giving $29 \mathrm{lb}$. and the year, equivalent to another stone having regard to sex allowance, won very easily by a length and a half, which might have been considerably increased.

A result of this was that the American colt started actually favourite for the Derby. $\mathrm{He}$ and Minoru were so nearly on the same mark that if a regular frequenter of the racecourse had 82 


\section{AND HER OFFSPRING}

been asked just prior to the start what was favourite he would have been as likely to mention one as the other. Admirers of Bayardo had, nevertheless, lost little of their confidence, many of them had lost none, and were delighted at the possibility of obtaining odds of 9 to 2 . The fact that Maher was riding much gratified a number of those who were interested in $\mathrm{Mr}$. Fairie's colt, but was not regarded by everyone as immensely in Bayardo's favour. The American jockey had previously won the Derby thrice in four years-on Sir James Miller's Rock Sand in 1903, Lord Rosebery's Cicero in I905, Major Eustace Loder's Spearmint in 1906, and in 1906 he had also won the Oaks on Lord Derby's Keystone II. Notwithstanding these victories, however, his percentage of successes at Epsom had been singularly low in comparison with the proportion of his victories on other courses, notably perhaps at Newmarket.

Descending the hill towards Tattenham Corner Sir Martin fell. He was almost in front at the time, and what effect the accident had on the animals who were following him can never be precisely ascertained. Spectators who were near the scene of the mishap varied greatly in their accounts of it, the jockeys who rode in the race told contradictory stories, as is much more the 


\section{GALICIA : HER FORBEARS}

rule than the exception in such cases, and from the neighbourhood of the winning-post it was impossible to make out, even approximately, what had occurred. I watched the race from the top of the Club stand, a good place for seeing-when other people's heads and hats do not obscure the view. I observed the wearer of Mr. Winans's black, white, and red hoops suddenly come to the ground, and some of the other runners being pulled out to avoid the fallen horse and jockey. Maher roughly calculated that he lost sixteen lengths. So far as I could make out Minoru near the rails escaped interference, and was fortunate in finding a clear course, as was also the case with Mr. Walter Raphael's Louviers.

Minoru, it may be remarked, had been drawn No. I on the rails, and his jockey kept him on the inside. When once Tattenham Corner had been rounded, however, four or five appeared to be in it, Bayardo not far behind, and I gazed with confidence to see him assert his old superiority. The inference is that he had been thrown out of his stride and was unable to recover it sufficiently to do himself justice. A hundred yards from home the race seemed to have resolved itself into a fight between Minoru and Louviers, though it was not quite certain that William the Fourth or Valens might not get up, and a 


\section{AND HER OFFSPRING}

very faint hope that Bayardo might do so still lingered. It was not to be, however. The bearers of the Royal purple and scarlet, and of the dark blue, scarlet hooped sleeves, flashed past the post as nearly as possible in a line, so much so that no one could say who had won, or whether, indeed, this was not a third instance of a dead heat for the Derby since the race was started in 1780 -the two previous ones having been between the Duke of Rutland's Cadland and Mr. E. Petre's The Colonel in I828, Sir John Willoughby's Harvester and Mr. J. Hammond's St. Gatien in I884. The scene of enthusiasm which followed the hoisting of the King's number need not be described. It is sufficient to say that Bayardo's subsequent running appeared most distinctly to prove that the Derby of 1909 was not won by the best horse.

Epsom, I 909.

One Hundred and Thirtieth Renewal of the Derby Stakes of $£ 6500$ (including $£ 500$ for nominator of winner), with $£ 400$ for second and $£_{2} 200$ for third, by subscription of $£_{50}$ each, h. ft. or $£_{5}$ if declared, with $£$ I 250 added; for three-year-olds, entire colts and fillies; colts 9 st., fillies 8 st. $9 \mathrm{lb}$. About one mile and a half. (299 entrants, viz. I 5 at $£_{50}$, I 84 at $£ 25$, and 100 at $£_{5}-£_{6450}$.)

His Majesty's br. c. Minoru, by Cyllene,

9 st. 


\section{GALICIA : HER FORBEARS}

Mr. W. Raphael's b. c. Louviers, 9 st. G. Stern

Lord Michelham's ch. c. William the

Fourth, 9 st. . . . . W. Higgs 3

Duke of Portland's b. c. Phaleron, 9 st. W. Earl o

Mr. C. S. Newton's b. c. Sandbath, 9 st. R. Keeble o

Mr. R. Mills' br. c. Prester Jack, 9 st. W. Saxby o

Mr. W. Raphael's b. c. Brooklands,

9 st. . . . . . D. Blackburn o

Mr. J. Buchanan's b. c. Diamond Stud,

9 st. • . • •

Lord Carnarvon's b. c. Valens, 9 st. . W. Halsey o F. Wootton o Mr. Fairie's b. c. Bayardo, 9 st. . D. Maher o Mr. J. Barrow's br. c. Strickland, 9 st. Wm. Griggs o Mr. H. G. Fenwick's br. c. St. Ninian,

9 st. . . . . . C. Trigg o

Mr. J. B. Joel's ch. c. The Story, 9 st. Walt. Griggs o Mr. A. H. Ledlie's b. c. Electric Boy,

9 st. . . . . . W. Bray o

Mr. L. Winans's ch. c. Sir Martin, 9 st. J. H. Martin o

Betting. - 3 to I against Sir Martin, 7 to 2 Minoru, 9 to 2 Bayardo, 8 to I Valens, 9 to I Louviers, 20 to I Phaleron and William the Fourth, 40 to I The Story, 50 to I Diamond Stud and Strickland, 66 to I each Electric Boy, Sandbath, St. Ninian, and Prester Jack. Won by a short head; half a length second and third. Sir Martin fell.

Bayardo went on to Ascot, and there his friends had an excellent opportunity of backing him for the Prince of Wales's Stakes, for bookmakers accepted short odds about the colt. He had to give $2 \mathrm{I}$ lb. to a filly called Verne, a daughter of Bill of Portland and La Vierge, who 86 


\section{AND HER OFFSPRING}

had made her first appearance in the Oaksnever having run as a two-year-old-and had finished third. It seemed to be supposed that she had a chance, but as a matter of fact she never won a race of any kind, and the three parts of a length by which Bayardo beat the Duke of Portland's Cattaro might have been largely extended.

Ascot, I 909 .

Prince of Wales' Stakes of $£_{50}$ each, h. ft., with $£_{1000}$ added, of which second received $£_{300}$ and third $£ 200$; for three-year-olds. New Course, about one mile five furlongs. (63 entrants- $£_{2}$ I 50 .)

Mr. Fairie's Bayardo, by Bay Ronald, 9 st. $5 \mathrm{lb}$.

D. Maher I Duke of Portland's Cattaro, 8 st. I 3 lb. Mr. J. B. Joel's Verne, 7 st. I 2 lb. . Walt. Griggs 3 Mr. J. W. Larnach's Via, 8 st. 8 lb. . B. Lynham o Mr. Leopold de Rothschild's King Charming, 8 st. 3 lb.

O. Madden

Betting.-6 to 4 on Bayardo, 7 to 2 against Verne, I 00 to I 2 Cattaro. Won by three-quarters of a length; five lengths second and third.

Bayardo's only other engagement at Ascot was for the St. James's Palace Stakes, and he was not brought out, Minoru being left to deal with a couple of opponents, as he did without difficulty; and it is to be suspected that Bayardo's absence here accounted for his price when he started ten days later for the Sandring- 


\section{GALICIA : HER FORBEARS}

ham Foal Stakes at Sandown Park. Some people appear rashly to have concluded that Mr. Fairie had been unwilling to meet Minoru and that consequently Bayardo was deteriorating, an idea without the faintest justification.

\section{Sandown Park, I909.}

Sandringham Foal Stakes of £2000, viz. £i 500 for owner and $£_{250}$ for nominator of winner, $£_{1} 00$ for owner and $£_{50}$ for nominator of second, and $£_{75}$ for owner and $£ 25$ for nominator of third; for three-year-olds; entrance $£_{2} 6, £_{\text {I I }}$ if declared by January 5, I909, or $£_{1}$ if declared by October 8, 1907. One mile and a quarter. (I 23 entrants, viz. 32 at $£_{26}, 5$ I at $£_{I I}$, and 40 at $£_{I}-£_{1724}$.)

Mr. Fairie's Bayardo, by Bay Ronald,

9 st. Io lb. . . . .

Mr. L. Neumann's Verney, 7 st. . J. Plant 2

His Majesty's Oakmere, 8 st. 2 lb. . Walt. Griggs 3

Mr. J. Buchanan's Chanteur, 7 st. 3 lb. J. Howard O

Mr. W. Raphael's Louviers, 9 st.

Io lb. . 4 . 8 st.

Duke of Portland's Baillet Latour, 8 st.

G. Stern o

$3 \mathrm{lb}$. . . . . W. Earl o Mr. H. Whitworth's Venti, 8 st. 3 lb. J. Thompson o Mr. H. M. Hartigan's Druce, 8 st. . E. Houlihan 0 Admiral Lambton's Fizzer, 7 st. 4 lb. F. Fox 0 Mr. W. B. Purefoy's Habana, 7 st. . C. Ringstead o

Betting.-2 to I against Louviers, 4 to I each Bayardo and Verney, 6 to I Chanteur, Ioo to 8 Oakmere. Won by one and a half lengths; two lengths second and third. Druce dwelt at the start. 



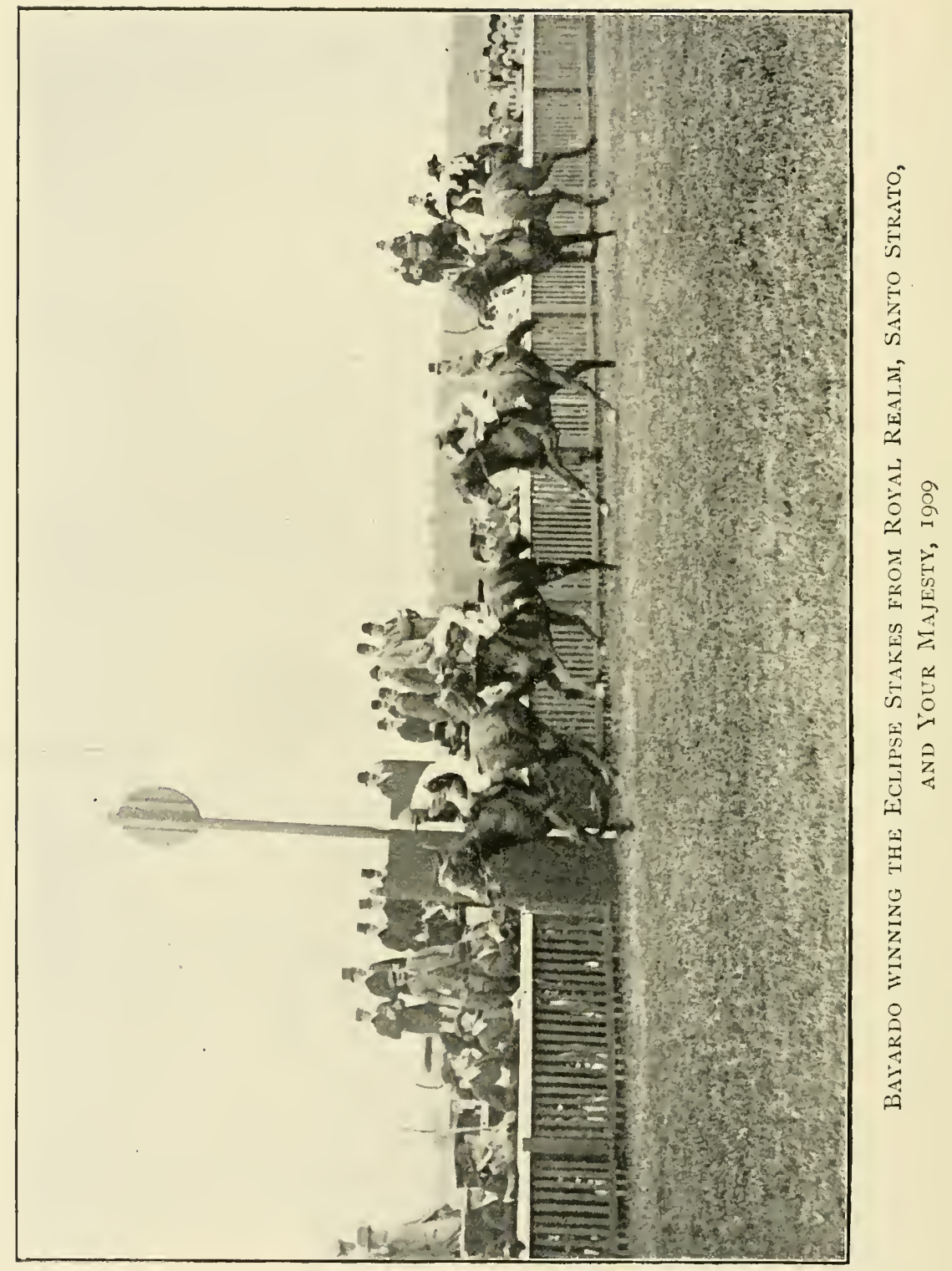




\section{AND HER OFFSPRING}

That Verney should have shared second favouritism with Bayardo is explained by the weights, for $3^{8} \mathrm{lb}$. is a desperate handicap, but it will be seen that Bayardo and Louviers carried the same burden, and the fact that the Derby form was wrong had not yet been recognised. A clearer perception of the real state of the case had arisen before the Eclipse Stakes. Your Majesty was a Leger winner, indeed he had won four of the five races for which he had started the previous season, and had been favourite for the Princess of Wales's Stakes at Newmarket, for which he had been beaten by Dark Ronald, a colt of whom a vast deal was thought. At Sandown the race was never in any sort of doubt, though Bayardo's jockey seemed to take particular pains to keep him behind the leaders until the moment for making his effort had arrived.

Sandown Park, 1909.

Twenty-second Renewal of the Ecr.IPSE STAkEs of $£$ I 0,000, of which owner of second received $£ 800$, of third $£_{\text {I I } 5}$, nominator of winner $£ 500$, and of second $£_{100}$; by subscription of $£_{5}$ each for three-year-olds if declared by October 8,1907 , or $\oint_{1} 0$ for four-yearolds if declared by March 26, I 907 ; if left in after those dates a further $£_{2} \mathrm{I}$ each; if left in after March 3 1, 1908 , a further $£_{24}$ for three-year-olds, or $£_{32}$ for four-year-olds; and if left in after January 5 , I 909, a further $£_{55}$ for three-year-olds, or $£_{52}$ for four-year-olds; with $£_{2501}$ added. Eclipse Stakes 


\section{GALICIA : HER FORBEARS}

Course, one mile and a quarter. (I 67 entrants, viz. 29 at $£_{1}$ I 5, I 5 at $£_{6}, 26$ at $£ 60,42$ at $£_{31,22}$ at $£_{26}, \mathrm{I}_{4}$ at $£_{\mathrm{I} O}$, and $\mathrm{I} 9$ at $£_{5}-£ 8870$.)

Mr. Fairie's Bayardo, by Bay Ronald,

3 yrs., 9 st. 2 lb. .

Mr. W. Hall Walker's Royal Realm,

4 yrs., 9 st. 8 lb. . . . Wm. Griggs 2

Mr. Leopold de Rothschild's Santo

Strato, 4 yrs., 9 st. I I lb. . O. Madden 3

Mr. J. B. Joel's Your Majesty, 4 yrs.,

ro st. . . . . . Walt. Griggs 0

Betting. -85 to 40 on Bayardo, I 00 to 30 against Your Majesty, Ioo to 9 Santo Strato, 100 to 6 Royal Realm. Won by two lengths; length second and third.

Thenceforth Bayardo's position was established, and how little had come to be thought of the Derby form by the time the Hurst Park Meeting was held in July the Duchess of York Plate afforded unmistakable evidence.

Hurst Park, I 909.

Duchess of York Plate of $£$ I 300 , viz. $£$ I ooo for winner, $£ 200$ for second, and $£_{100}$ for third; for threeyear-olds; entrance $£_{2} \mathrm{I}, £_{\mathrm{I}} \mathrm{I}$ if declared by March 30 , I 909 , or $£$ I if declared by March $3 \mathrm{I}, 1908$. One mile and a quarter. ( 7 I entrants, viz. 2 I at $£_{2 \mathrm{I}}, 37$ at $£_{\mathrm{II}}$, and $\mathrm{I}_{3}$ at $£_{\mathrm{I}}-£_{979}$.)

Mr. Fairie's Bayardo, by Bay Ronald, 9 st. Io lb. . . . . . D. Maher I Lord Carnarvon's Valens, 9 st. Io lb. . F. Wootton 2 Sir Wm. Cooper's Perola, 9 st. 7 lb. . B. Dillon 3

Betting.-I I to 2 on Bayardo, 9 to I against Valens. Won by two lengths; bad third. 


$$
\text { . }
$$




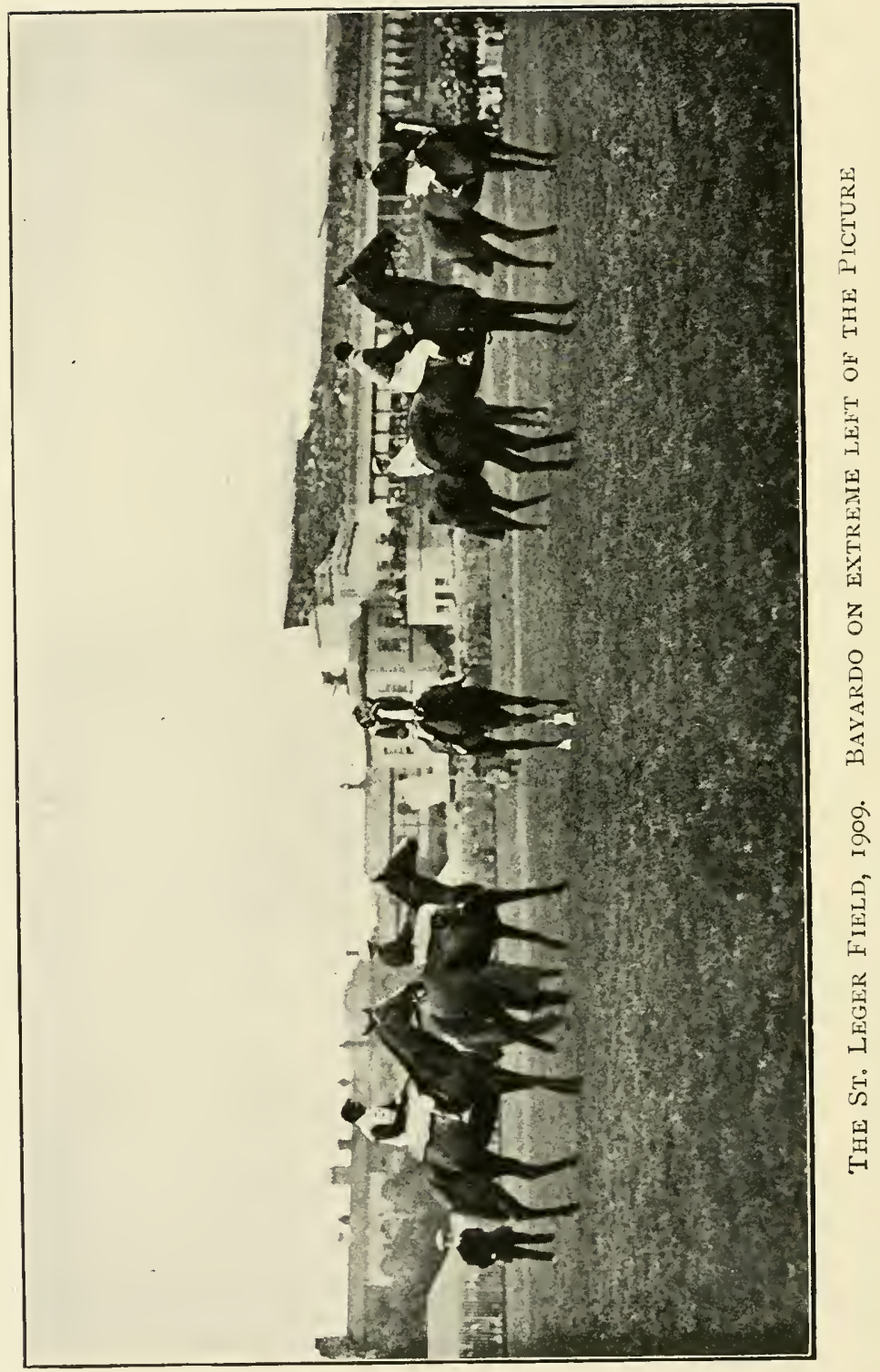




\section{AND HER OFFSPRING}

Valens had been doing distinctly well since the Derby. He had won the Whitsuntide Plate at the previous Hurst Park Meeting, the Homebred Three-Year-Old Cup at Gatwick with odds of roo to 6 on him, and had been second for the Hardwicke, he, as a three-year-old, giving the four-year-old Primer $4 \mathrm{lb}$, and running him to half a length.

After the Duchess of York Plate on the 24th July, Bayardo was trained for the Leger, in which the struggle between him and Minoru was to be renewed. Richard Marsh was quite satisfied with Minoru's prospects, entirely as the Derby form had been upset; for at Epsom Minoru had beaten Valens scarcely a length and what had happened when Valens met Bayardo had been seen.

Doncaster, 1909.

St. Leger Stakes of $£ 6500$ for winner, $£_{400}$ for second, and $£_{200}$ for third, by subscription of $£_{50}$ each, h. ft., or $£_{5}$ if declared, with $£_{1} 755$ added ; for threeyear-olds ; entire colts 9 st. and fillies 8 st. I I lb.; nominator of winner received $£_{500}$ out of stakes. Old St. Leger Course, about I mile 6 furlongs 132 yards. (310 entrants, viz. 7 at $£_{50}$, 174 at $£ 25$, and 129 at $£ 5-£ 6450$.)

Mr. Fairie's b. c. Bayardo, by Bay Ronald, 9 st. . . . . D. Maher I Lord Carnarvon's b. c. Valens, 9 st. . F. Wootton 2 Mr. W. Astor's ch. c. Mirador, 9 st. . B. Dillon 3 


\section{GALICIA : HER FORBEARS}

His Majesty's b. c. Minoru, 9 st. . H. Jones 4 Mr. J. B. Joel's ch. c. The Story, 9 st. Walt. Griggs 0 Mr. H. J. King's ch. c. Carrousel, 9 st. C. Trigg o Mr. J. Lowry's ch. c. Bachelor's Double,

9 st.

J. Thompson 0

Betting.-I I to Io on Bayardo, 7 to 4 against Minoru, I 00 to 8 Valens, Ioo to 6 Bachelor's Double, 33 to I The Story, 40 to I Mirador. Won by one and a half lengths; half length second and third.

I may add my brief comment, written at the time in the Illustrated Sporting and Dramatic Neas:

Marsh has seen so much of the ups and downs of racing that he rarely ventures to be anything like sanguine. He evidently did, however, most firmly believe that Minoru would, indeed that he must, win the Leger. He had never before got the King's colt quite so well, Minoru had not for a day been sick or sorry, had apparently come on, stayed well, fully retained his action, everything was in his favour. "I know I have to meet a good one in Bayardo," he remarked to me, "but I can tell you that Bayardo has to meet a good one in mine!" Well ! Bayardo won, as I thought he would, or rather not quite as I thought he would, for I did think he would have to stretch himself out to beat Minoru, and no stretching was required. But for the facts that I had talked for a long time to Marsh on the morning of the race, 92 


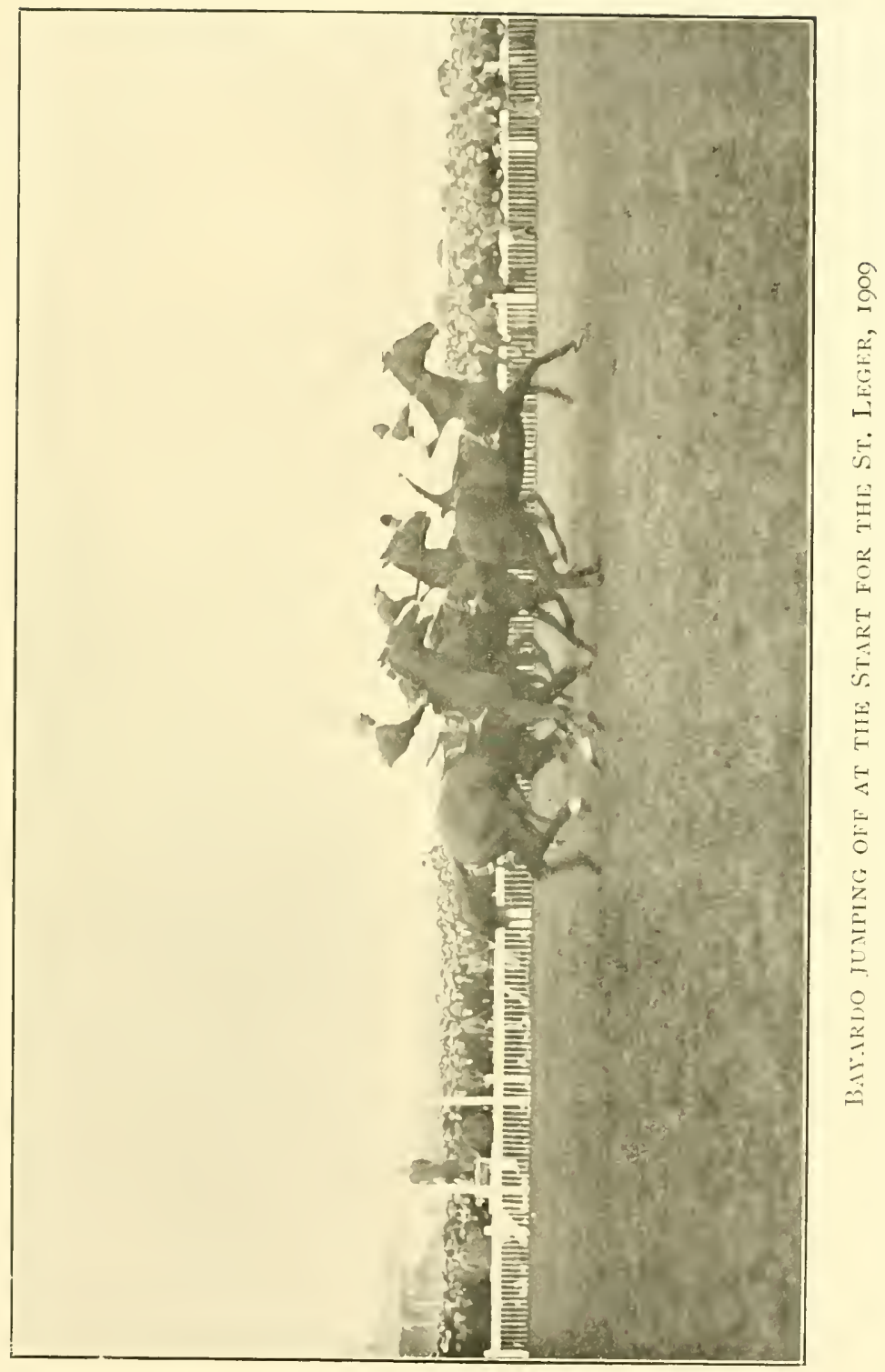





\section{- AND HER OFFSPRING}

knew that Minoru was at his very best, and had the evidence of my eyes to confirm it so far as looking goes-though Marsh's opinion was more than ample-I should have suspected that all could not have been well with Minoru, so badly did he run. Not for a moment did he suggest the possibility of success, and we gazed in amazement when for a few moments it really appeared as if Mirador and Valens had it between them. Could it bee that one more 40 to I chance was to win? As we wondered, Maher brought up Bayardo, and the race was over. Three strides did it. The others could not live with him for two seconds when it came to racing. Mr. Fairie was escorted by a bevy of friends to the paddock, and though naturally the failure of Minoru disappointed a multitude of people, the cheers which welcomed back Bayardo were hearty. Probably it was Lemberg's defeat that raised doubts with regard to his brother, for on Wednesday afternoon, I I to 8 having been laid on Bayardo the day before, a shade of odds against him was obtainable, and at one time 6 to 4 was taken about Minoru. Why the King's colt ran so badly is inconceivable.

There may be some excuse for Minoru. He only won a single race afterwards, and suffered 


\section{GALICIA : HER FORBEARS}

from an affection of the eyes which not improbably influenced his general health. He never looked like winning, nor did Bayardo ever look like being beaten. So little had the Leger taken out of him that it was thought he might just as well be produced to run for the Doncaster Stakes on the Friday, and this proved a mere exercise canter.

\section{Doncaster, 1909.}

Doncaster Stakes of $£$ Io each starter, with $£_{500}$ added, of which nominator of winner received $£_{50}$, and owner and nominator of second each $£_{25}$; for threeyear-olds; entrance $£_{5}$. One mile and a half over Old Course. (64 entrants, 3 of which were withdrawn on payment of fine under Rule $108-£_{475}$.)

Mr. Fairie's Bayardo, by Bay Ronald, 9 st. 5 lb. . . . . . D. Maher I Mr. L. Neumann's Verney, 7 st. 9 lb. . F. Wootton 2 Mr. George Faber's Great Peter, 8 st. $7 \mathrm{lb}$. . . . . . W. Bullock 3 Mr. Reid Walker's Duke Michael, 8 st. $9 \mathrm{lb}$.

. W. Higgs o

Betting.- 7 to I on Bayardo, IO to I against Verney, I 00 to 7 Duke Michael. Won by a length; four lengths second and third.

Mr. Fairie was not in the least afraid, indeed, of keeping his colt busy, and he was sent to Newmarket for the Second October Meeting, where he had a couple of engagements, both of which 94 


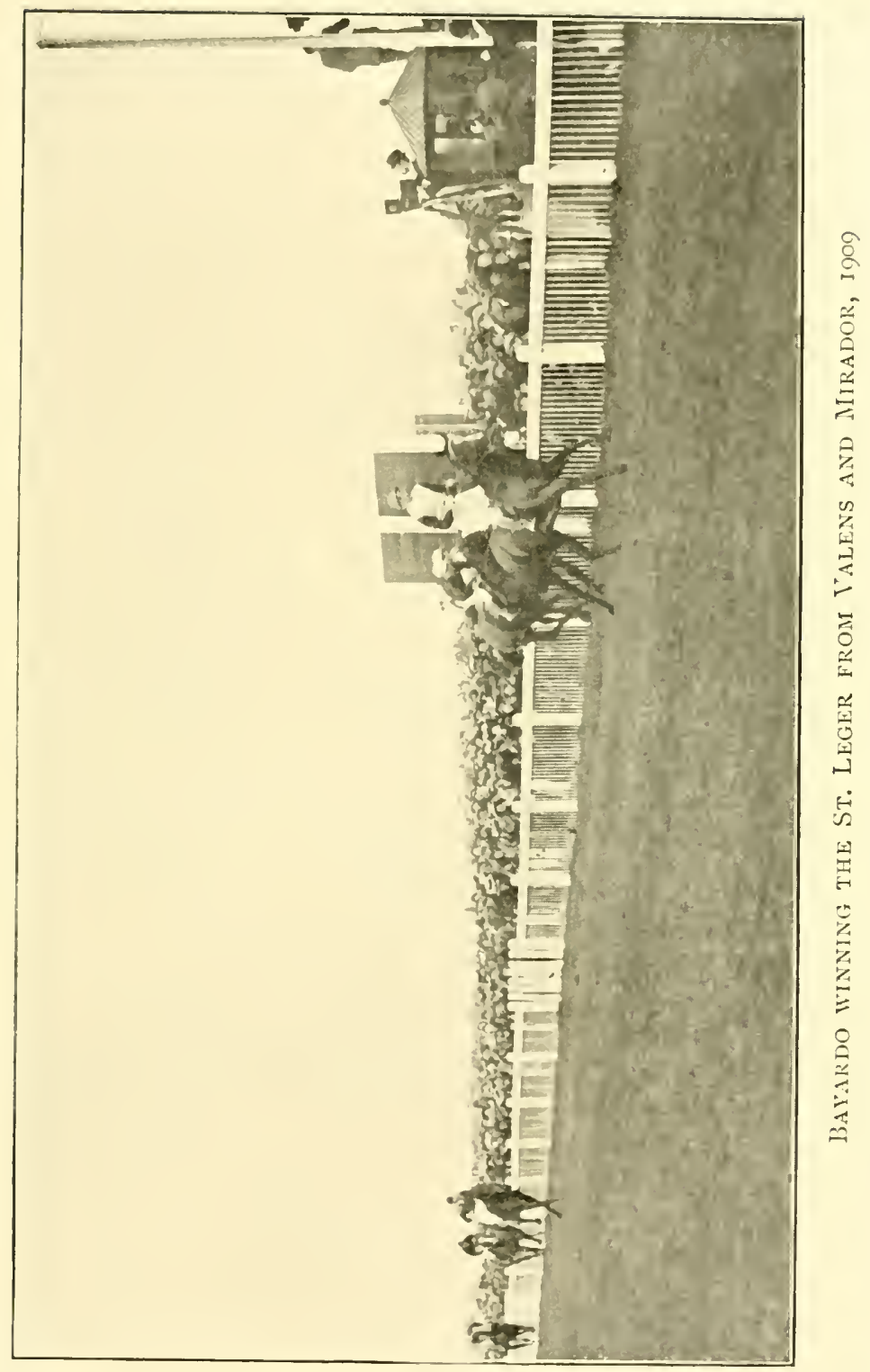





\section{AND HER OFFSPRING}

he was to fulfil. The first was in the Champion Stakes on the Tuesday.

Newmarket, 1909.

Champion Stakes of $£_{50}$ each, $20 \mathrm{ft}$. (to fund), with $£_{1000}$ added, of which second received $£_{150}$ and third $£ 50$; for three-year-olds and upwards. A.F. One mile and a quarter. (42 entrants- $£ 900)$.

Mr. Fairie's Bayardo, by Bay Ronald, 3 yrs., 8 st. 7 lb. (car. 8 st. 8 lb.) . D. Maher I Mr. J. B. Joel's Dean Swift, aged, 9 st. . Walt. Griggs 2 Mr. W. Hall Walker's White Eagle,

4 yrs., 9 st. . . . . W. Saxby 3

Betting.-9 to 4 on Bayardo, 5 to I against Dean Swift, 1 I to 2 White Eagle. Won by a neck; length second and third.

Dean Swift had proved himself something better than a handicap horse, and it was no discredit to Bayardo that he should not have absolutely cantered away from the dual winner of the City and Suburban. In the Lowther Stakes on the Thursday it will be perceived how hopeless White Eagle's chance was, for here he was trying to give Bayardo $\mathrm{I} 2 \mathrm{lb}$., and in the Champion Stakes Bayardo had beaten him in receipt of just half as much.

Newmarket, I 909.

Lowther Stakes of $£ 20$ each, h. ft. (to fund), with $£ 500$ added, of which second received $£_{50}$, third saved stake; for three-year-olds and upwards. Last 


\section{GALICIA : HER FORBEARS}

one mile and three-quarters of Cesarewitch Course.

(37 entrants-£470.)

Mr. Fairie's Bayardo, by Bay Ronald, 3 yrs., 9 st. 7 lb. . . . .

Mr. W. Hall Walker's White Eagle, 4 yrs.,

D. Maher I

Io st. 5 lb. . . . W. Saxby 2 Capt. Laing's Rousay, 5 yrs., 8 st. I 3 lb. . R. Keeble 3

Betting.- 100 to 9 on Bayardo, 100 to 8 against White Eagle. Won by one and a half lengths; bad third.

That Bayardo had been so liberally engaged proved fortunate. He was in eighteen races as a three-year-old, and started for no fewer than thirteen of them. On the 2 Ist of October he reappeared at Sandown on the Eclipse Stakes course for the Sandown Foal Stakes, his third essay, it will be perceived, over this mile and a quarter, he having taken the Sandringham Foal Stakes at the Summer Meeting as recorded, and he won very easily, though the verdict was the length and a half. That seemed to be the distance which Maher usually thought sufficient. It was by a length and a half that he had won the Lowther Stakes, much about the same distance in the Doncaster Stakes, a length and a half again in the Leger, rather more-two lengths -in the Duchess of York Plate and in the Eclipse, the familiar length and a half again in the Sandringham Foal Stakes. 


\section{AND HER OFFSPRING}

Sandown Park, I 909 .

Sandown Foal Stakes of $£ 2000$, viz. $£$ I 500 for owner and $£_{25}$ o for nominator of winner, $£_{1} 00$ for owner and $£_{50}$ for nominator of second, and $£_{75}$ for owner and $£_{2} 5$ for nominator of third, for threeyear-olds ; entrants $£_{2} 6, £$ I I if declared by January 5 , I 909, or $£_{\mathrm{I}}$ if declared by October 8 , I 907 ; of surplus, viz. £I I 9 , second received two-thirds and third the remainder; Eclipse Stakes Course, one mile and a quarter. (I 84 entrants, viz. 5 I at $£ 26$, 66 at $\AA_{\mathrm{I} I}$, and 67 at $\left.£ \mathrm{I}-£ \mathrm{I} 724\right)$.

Mr. Fairie's Bayardo, by Bay Ronald, 9 st. 7 lb. . . . . D. Maher I Mr. L. Neumann's Shikaree, 7 st. 9 lb. . F. Wootton 2 Mr. Reid Walker's Legatee, 7 st. . . S. Wootton 3 Mr. Leopold de Rothschild's King Charming, 8 st. 3 lb. . . . . O. Madden o Betting.- I 00 to 7 on Bayardo, 20 to I against Shikaree, 25 to I King Charming, 66 to I Legatee. Won by a length; one and a half lengths second and third.

Bayardo returned to Newmarket for the Houghton Meeting, and as I recollect behaved there as if he were getting rather tired of the place, being unwilling to go to the post for the Limekiln Stakes, not knowing what a very easy task was before him, and Maher had to take him round at the back of the stands.

Newmarket, I 909.

Limekiln Stakes of $£_{25}$ each, io $\mathrm{ft}$. (to fund), with $£_{500}$ added, of which second received $£_{100}$; for three- 


\section{GALICIA : HER FORBEARS}

year-olds and upwards. A.F. One mile and a quarter. (42 entrants- $£_{42} 5$ ).

Mr. Fairie's Bayardo, by Bay Ronald,

3 yrs., 9 st. 8 lb. . . . D. Maher. I

Mr. H. P. Whitney's Perseus II, 3 yrs.,

8 st. I 3 lb. . . . . J. H. Martin 2

Betting.-33 to I on Bayardo. Won by fifteen lengths.

He wound up the season at Liverpool.

Liverpool, I 909.

Liverpool St. Leger of $£ 700$, of which second received $£_{50}$; for three-year-olds. Entrance $£_{20} ; £_{13}$ if declared by January 5 , I 909, or $£_{3}$ if declared by March 3 I, I 908. One mile and a half. (32 entrants, viz. I 6 at $£_{20}$, IO at $£_{1} 3$, and 6 at $£_{3}-£_{630}$ ).

Mr. Fairie's Bayardo, by Bay Ronald, Io st. D. Maher I Mr. Reid Walker's King Amyntas, 8 st.

$4 \mathrm{lb}$. . . . . . W. Higgs 2

Betting.-66 to I on Bayardo. Won by half a length.

His season's work brought in $£ 24,797$. One result of it was to raise $\mathrm{Mr}$. Fairie to the first place in the list of winning owners, with $f, 37,7$ I 9 to his credit, which was considerably more than twice as much as the total of his immediate follower, the Duke of Portland, with $f_{15}, 064$; and another effect was to elevate Bay Ronald to the second position in the table of winning sires. This was headed by Cyllene with $£ 35,55^{\circ}$, Bay 


\section{AND HER OFFSPRING}

Ronald following with $£_{\triangleleft} 34,36$ I. Bayardo's figures have been given : besides the Princess of Wales's Stakes Dark Ronald won a couple of other races, the three yielding $f_{0} 7 \mathrm{r} 04$.

Throughout the winter Bayardo went on in the right way, his owner's objective being the Ascot Cup. He was ready, however, by the Craven Meeting, and fulfilled his engagement in the Fiftieth Newmarket Biennial. It was hardly supposed to be a race, but it will be seen that the jockey was contented to win by a sufficient, though not extensive, margin.

Newmarket, I 9 I 0.

Second Year of Fiftieth Newmarket Biennial Stakes of $£ 25$ each, I $0 \mathrm{ft}$. for acceptors, with $£_{500}$ added, of which second received 10 per cent. and third 5 per cent.; for four-year-olds; entrance $£_{5}$, only $\mathrm{ft}$. if declared; last one mile and a half of Cesarewitch Course. (22 entrants, ft. declared for $7-£ 573$, IOs.).

Mr. Fairie's Bayardo, by Bay Ronald, Io st. . . . . . D. Maher I Mr. George Faber's Great Peter, 9 st. . B. Dillon 2 Duke of Portland's Cattaro, 9 st. . . W. Earl 3 Mr. H. G. Fenwick's Tocher, 8 st. . J. H. Martin O

Betting.- I 100 to 9 on Bayardo, 100 to 7 against Cattaro. Won by three-quarters length; six lengths second and third.

A consequence of this race was to make people imagine that Great Peter must be a better 


\section{GALICIA : HER FORBEARS}

horse than he was in fact, and a good deal of money was therefore lost on him, for he never won afterwards under Jockey Club Rules, though when put to jumping he was fairly successful in carrying off minor stakes.

Bayardo went on to Chester to run for the Vase, which during the last few years has usually attracted a few good animals, and here there was a sensational finish.

Chester, I 9 IO.

Chester VAse of $£_{2} 2000$ (a Vase value $\oint_{1}$ IOO and remainder in specie), of which owner of second received $£ 200$ and of third $£ 100$; nominator of winner $£_{125}$, of second $£_{50}$, and of third $£_{25}$; by subscription of $£_{1}$ for three-year-olds or $£_{2}$ for fouryear-olds; if left in after October I 3,1908 , a further Ero for three-year-olds; if left in after March $3 \mathrm{I}$, I 908 , a further $£ 10$ for four-year-olds; if left in after March 30, I 909, a further $\mathscr{L}_{10}$ for each; and if left in after January 4, I 910 , a further $£ 8$ for each; with $£ 293$ added. One mile and a half. (I 49 entrants, viz. I 2 at $£_{30}$, Io at $£_{29}$, I 2 at $£ 22,12$ at $£_{2} \mathrm{I}, 26$ at $\oint_{\mathrm{I}} 2, \mathrm{I} 2$ at $£_{11}, 32$ at $£_{2}$, and 33 at $£ 1-\mathscr{L}_{1595}$.)

Mr. Fairie's Bayardo, by Bay Ronald, 4 yrs., 9 st. $9 \mathrm{lb}$. . . . . D. Maher I

Lord Michelham's William the Fourth, 4 yrs., 9 st. $7 \mathrm{lb}$. . . . . B. Dillon 2

Mr. D. M'Calmont's Malpas, 3 yrs., 6 st.

$13 \mathrm{lb}$. • . . . J. Evans 3

Mr. Reid Walker's Duke Michael, 4 yrs., 8 st. 4 lb.

W. Higgs 0 



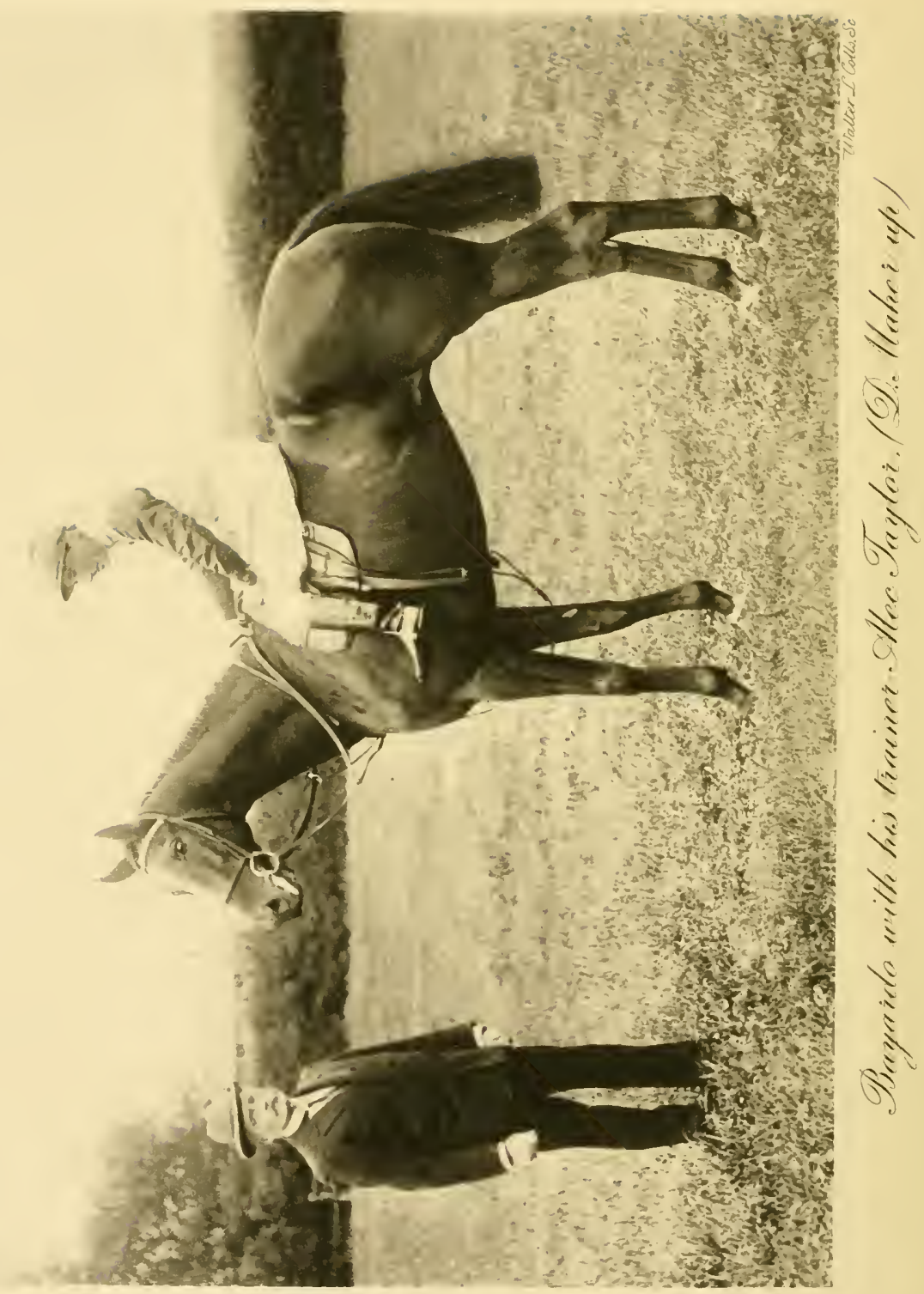




\section{AND HER OFFSPRING}

Mr. L. de Rothschild's Santa Fina, 3 yrs.,

7 st. $6 \mathrm{lb}$. . . . . H. Watts o

Duke of Westminster's Kalvemor, 3 yrs.,

7 st. 4 lb. . . . . . F. Fox o

Betting. - 5 to $\mathrm{I}$ on Bayardo, 10 to I against William the Fourth, roo to 6 Santa Fina. Won by a head; threcquarters length second and third.

William the Fourth had not been out since the previous Ascot, when he won the Ascot Derby from three moderate opponents. He had, however, been doing well under the charge of Mr. Gwyn Saunders-Davies at Michel Grove, and if the quotation of the betting is accurate some people were willing to take ro to I against him, which seemed a rash proceeding before the start. William the Fourth only ran once afterwards, and during the three seasons he was in training only won the single race at Ascot. Of course, seeing how near he was in the Derby, his friends protested that he "ought to have won" it. Such protestations are common, though at the same time it must be admitted that of late years the Derby has on several occasions been won by horses who could not have been the best in the race.

Bayardo, so far from frightening away rivals in the Gold Cup, was one of the largest field which had ever started for that trophy since the IOI 


\section{GALICIA : HER FORBEARS}

contest for it was originated in 1807 . It is very seldom in its history that the starters have run into double figures. The Marquis of Hastings' Lecturer was one of ten in 1867 , and it was not until I902, William the Third's year, when eleven went to the post, that double figures were again reached. The reason is obvious: so very few horses have any pretensions to win, and their owners do not consider it worth while to submit them to the ordeal of the necessarily severe preparation for a hopeless task.

In Igro, however, Bayardo was one of a field of thirteen. In the two previous years there had been half a dozen starters, and there was the same number the year following. Considering Bayardo's record the ring seems to have been extraordinary liberal in laying 7 to 4 against him. This was due to the fact that doubts must always exist as to the ability of a horse to last two miles and a half until he has proved his ability to do so, though Alec Taylor, who had charge of Bayardo, has been strikingly successful in training the winners of long-distance races-as his father was before him-and his confidence in the son of Bay Ronald was supreme. That Mr. Louis Winans's Sir Martin should have been backed at 9 to 2 must be considered strange, for Joseph Cannon did not appear to be entirely satisfied 



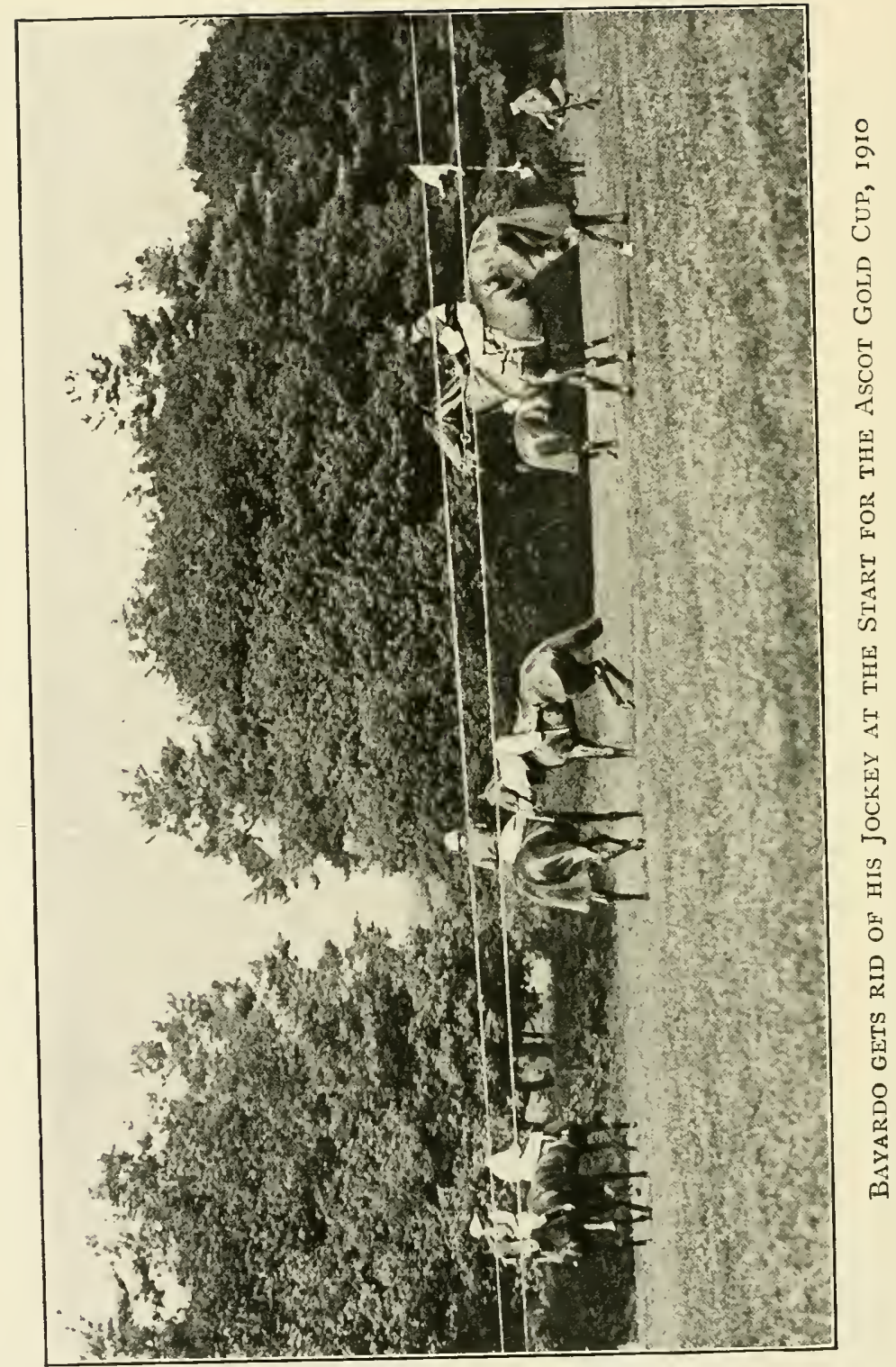




\section{AND HER OFFSPRING}

that the American colt would stay, as he proved quite unable to do, and I suspect that he never recovered from the effect of his exertions. It is rather the exception for an American-bred horse to stay. Sir Martin, however, had been tried, in the opinion of his experienced trainer, good enough to win the Derby, and that there was no mistake about the trial was sufficiently demonstrated by the fact of his having had little difficulty in beating so good a horse as Bachelor's Double, to say nothing of Louviers who had lost the Derby by only a head, in the Coronation Cup at Epsom over the Derby course. Louviers finished nearly six lengths behind Sir Martin in the Epsom race, Batchelor's Double beaten a length and a half.

Few years pass in which some French owners do not send over in the hope of winning the Gold Cup, and their efforts have on various occasions been successful-with Maxim II in 1903, Elf II in 1898 , Verneuil in 1878 , Boiard in 1874 , Henry in 1872 , Mortemer in $187 \mathrm{I}$, and Gladiateur in 1866. Two French horses arrived to run against Bayardo, one with the disagreeable name of Sea Sick II, a colt who had much distinguished himself in his own country, and Aveu, of whom much less was thought. Sea Sick II, a son of Elf II whose name has just been mentioned, had won half a dozen 


\section{GALICIA : HER FORBEARS}

races in France in eight attempts as a three-yearold, and had been second for the valuable Prix du Président de la République, worth nearly Ł5000. He was a great stayer. One of his successes had been in the Prix de Longchamps, two miles and a furlong, another in the Prix de Chantilly over a slightly longer course, a third, the Prix Gladiateur, a few yards short of four miles. That he had retained his form was shown by a couple of victories gained shortly before his visit to Ascot, and it may be noted that on his return to France, in his first essay there, he took the Prix de Longchamps for the second time. He was, indeed, strongly fancied for the Cup at Ascot.

Ascot, 1910.

Gold Cup, value $£_{500}$, with $£_{3500}$ in specie, added to a Sweepstakes of $£ 20$ each, h. ft., of which second received $£_{700}$ and third $£_{300}$; for entire colts and fillies, three years old and upwards. Two miles and a half, starting at the Cup Post and going once round. (59 entrants- -3700.$)$

Mr. Fairie's Bayardo, by Bay Ronald,

4 yrs., 9 st.

D. Maher I

Mr. W. K. Vanderbilt's Sea Sick II,

5 yrs., 9 st. 4 lb. .

Mr. W. W. Bailey's Bachelor's Double,

4 yrs., 9 st. . . . . H. Randall 3

Mr. J. B. Joel's Pure Gem, 6 yrs., 9 st. 4 llb. Walt. Griggs 0 Lord Michelham's Southanan, 6 yrs.,

9 st. 4 lb. .

F. O'Neill 2

H. Stokes o 


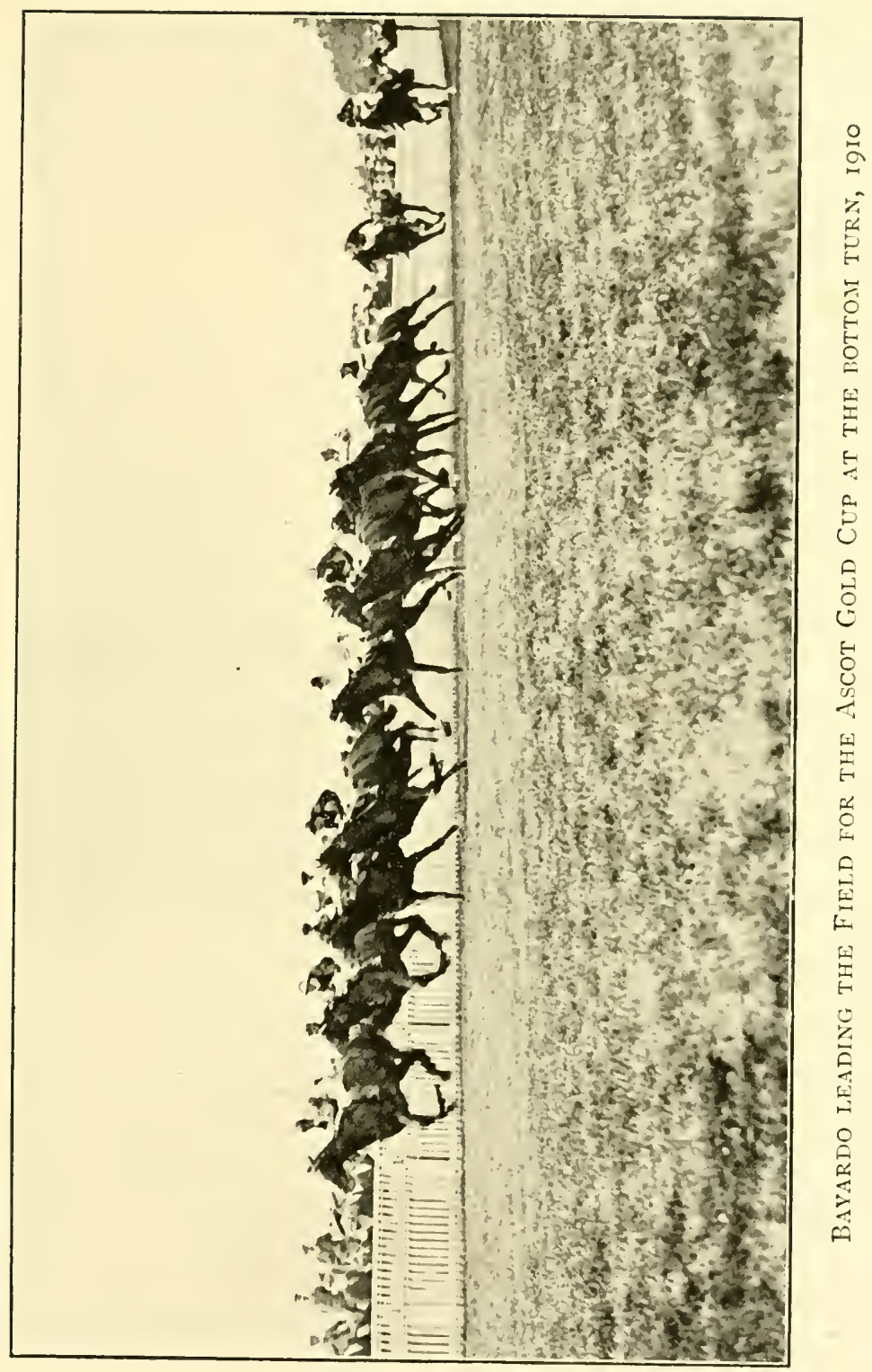





\section{AND HER OFFSPRING}

Mr. W. Hall Walker's Royal Realm, 5 yrs., 9 st. 4 lb. . . . Wm. Griggs o Mr. A. Aumont's Aveu, 4 yrs., 9 st. . C. Childs o Mr. C. S. Donnelly's Buckwheat, 4 yrs., 9 st. . . . . . W. Saxby o Mr. H. J. King's Carrousel, 4 yrs., 9 st. H. Jones o Lord Michelham's William the Fourth,

4 yrs., 9 st. . . . . B. Dillon o Mr. L. Winans's Sir Martin, 4 yrs., 9 st. J. H. Martin O Mr. Carl Meyer's Apache, 3 yrs., 7 st. 7 lb. (car. 7 st. 8 lb.). . . Mr. J. A. de Rothschild's Bronzino, 3 yrs., 7 st. 7 lb. . . . . F. Fox o

Betting. -7 to 4 against Bayardo, 9 to 2 Sir Martin, 6 to I Sea Sick II, 7 to I Bachelor's Double, roo to 9 William the Fourth, 100 to 7 Buckwheat, 100 to 6 Avue, 25 to I each Apache and Bronzino. Won by four lengths; head second and third.

Bayardo's victory was gained in the most brilliant and convincing fashion. When Maher asked him to leave his horses he came to the front and cantered home without the semblance of effort. This finish for the Ascot Cup dwells in the memory, and, great as Bayardo's reputation was, the race vastly raised and strengthened it. Only a great horse could win as he did.

I may perhaps be allowed to reproduce the description I wrote of the event at the time :

I am inclined to fancy that Bayardo astonished everybody last week. Of course, Mr. Fairie has 105 


\section{GALICIA : HER FORBEARS}

always had a tremendous opinion of his horse, and Alec Taylor has seen him every day for years past. They must have known something like what he was; but nothing that happens on a horse's own training ground can demonstrate just what he will do in the course of a race for the Ascot Cup against a good representative field. That is the point-the "good representative field." At home perhaps the Cup horse gallops with a couple of others, and there is something to jump in and lead him for the last mile. You never get the conditions in private that you get in public, and that is why I doubt whether anybody could be confident Bayardo had it in him to give the electrifying exhibition which will make his victory memorable. Why Maher has ridden him in the style with which we were familiar before Ascot it is utterly impossible to guess. On the morning of the Cup Day an owner who is among the very best judges of horses and racing that I ever met, and who, moreover, happens to be particularly well acquainted with the Manton stable, replied to my question whether he intended to back Bayardo with an unhesitating negative, and he added, "I will never back a horse that is not genuine for an Ascot Cup!" That was the impression of Bayardo that he entertained. It may be that all Maher's wins on I06 


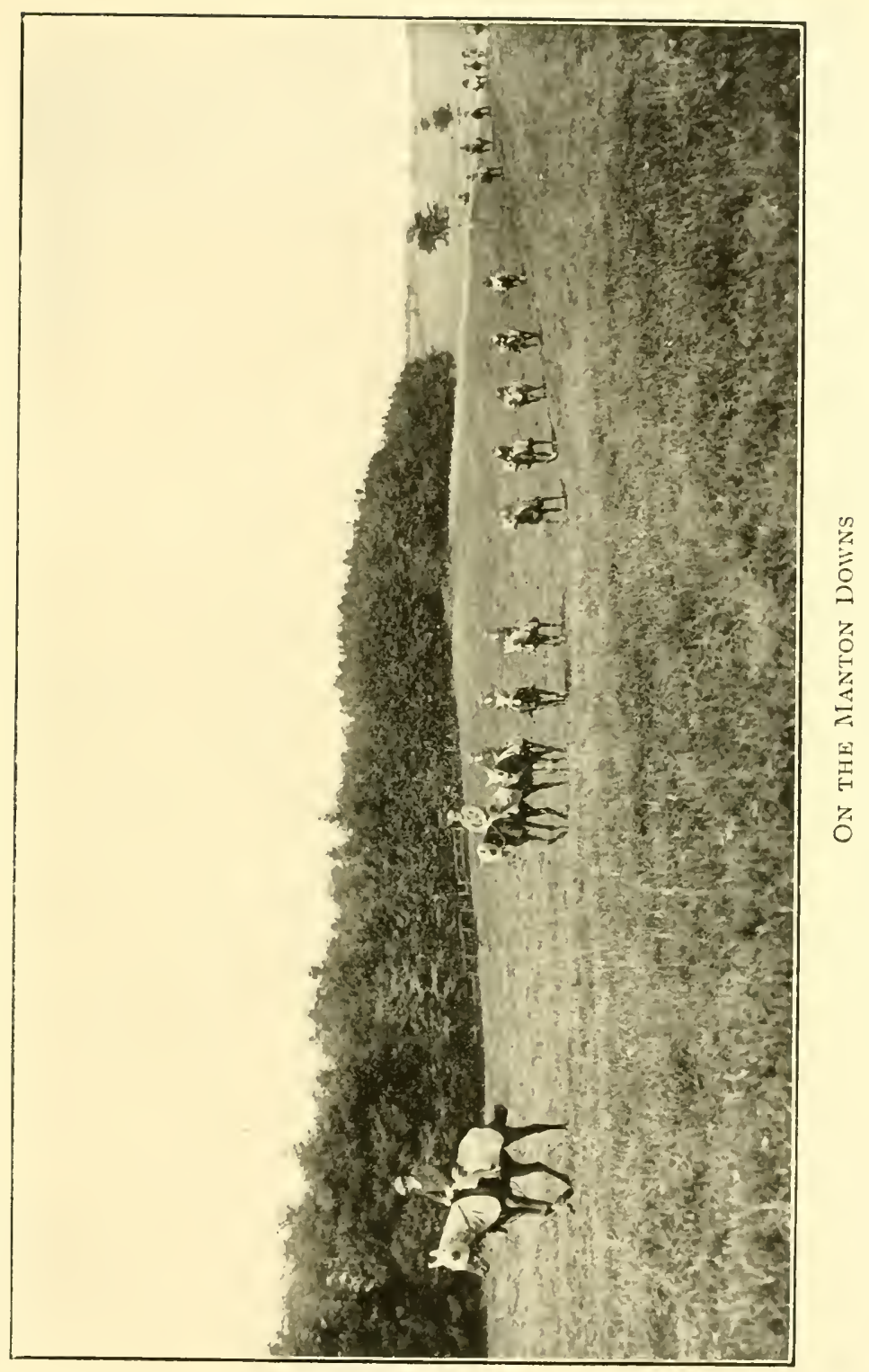





\section{AND HER OFFSPRING}

Bayardo have been miracles of unexampled genius in the way of jockeyship. The effect they have had is that just indicated. He has always striven to keep the colt behind others, and the well-nigh universally accepted explanation was that he "did not want to let Bayardo see what he had to do." There can be no sort of doubt that if any accident had prevented Bayardo from running for the Cup he would have left the Turf under a strong suspicion of being a rogue, or at least of having a decided tendency to roguishness, and this because of the way in which Maher has been pleased to ride him.

Now we all know how utterly unjust such a suspicion would be. No horse that ever trod on racing plates could have given a more gallant and impressive exhibition. The days have long since passed when French horses were lightly esteemed, and a particularly accomplished trainer's opinion with regard to Sea Sick II was that he would prove invincible. He stays, he has speed, he had never been so well in his life. He was genuine, and in France they knew, or thought they knew, all about Bayardo's suspected inclination to turn it up if he saw a long stretch of galloping ground in front of him. It has now been proved that he has not this inclination; but why on earth has Maher apparently been so 107 


\section{GALICIA : HER FORBEARS}

careful to persuade us that he has had? I am quite certain that the suspicion would have influenced his stud prospects. However, there was Sea Sick to beat, and was there not also Sir Martin? I have often commented on the fact that American horses do not stay. That is now a commonplace. But Americans who knew most about Sir Martin were persuaded that he was an exception. Many people, on the ground that American horses do not stay, would not back him for the Coronation Cup. He won over that mile and a half course in a canter, which certainly suggested that he could have gone on a much longer way. Of course, it is very easy to declare that a son of Ogden was sure not to last over the Ascot Cup course ; but this absurdly obvious circumstance was not realised till everyone had seen Sir Martin tailed off. Doubtless a mile and a half at Epsom and two miles and a half at Ascot are different things; nevertheless, in the face of Bayardo and of Sea Sick, a great many men, not necessarily all fools, took 4 to I about Sir Martin; and a good many writers about racing, not congenital idiots, expounded the opinion that his chance was a great one. A rank non-stayer would not have won the Coronation Cup without an effort.

Sir Martin at home had galloped the Cup Io8 


\section{AND HER OFFSPRING}

distance unfalteringly; but that is the point discussed above-to do this at home is one thing, to do it in a veritable Cup race is another. Bachelor's Double, on the other hand, had been trained for the Hunt Cup mile, and simply for this reason it was hard to imagine that he could stay sufficiently well to be dangerous. If he should be trained for the Gold Cup next year, it is far from unlikely that he may win it; but it would require an equine marvel to carry off this Cup without a preparation, and it is most astonishing that he should have got where he did. Nobody out of the William the Fourth stable credited him with being nearly good enough, though his owner's refusal to pick up the Triennial on Tuesday, which the colt could not have missed, betokened faith. It is not the first time that the substance has been lost for the sake of the shadow. Men who, as it now appears, should have been. wiser, backed Buckwheat both ways. He was "a better horse than people thought," I was assured. Beyond these it seemed quite needless to look. Pure Gem could not possibly be regarded as a Cup horse, nor could Royal Realm, though it is open to those with a fancy for supporting outsiders to add, "Nor could Bomba last year, or Throwaway, who was better than Bomba, surely, a few years before." This would be a I 09 


\section{GALICIA : HER FORBEARS}

retort rather difficult to answer effectively; for if you replied, "That sort of thing is not likely to happen again," there was the answer, "It was not in the least likely to happen last year; only it did !"

It is rather quaint to see a horse conscientiously making running for a stable companion to whom the pacemaker's efforts are not of the remotest service. Southanan performed this duty for William the Fourth, who could not take the least advantage of it; and it may be incidentally remarked that placing William the Fourth to win races will not be easy, for he is likely to find something to beat him in the Cups, and as for a handicap, his having run Bayardo to a head at 2 lb. will ensure him plenty of poundage. I do not know if it is true that he has broken down. Sea Sick's jockey was not afraid to make use of him, and when Southanan retired, having had enough of it, the French horse went on. Unless Bayardo could really stay (my friend the good judge mentioned above finally backed him because he looked so beautiful), the race must go to France; O'Neill was bent on running them out of it if it was to be done; and meantime, where were Bayardo and Sir Martin? Maher had been much nearer last than first for half the journey, and it was not till about a mile from 


\section{AND HER OFFSPRING}

home that somebody near me remarked, "Bayardo is going up a bit." He had improved his position and was fifth or sixth-which seems an odd thing to write of a race for an Ascot Cup, the average number of runners being about four. Then, some six furlongs from home, Bayardo shot out in a fashion which can only be described as phenomenal. Maher had won in half a dozen strides. Of course, there was a good distance still to go, but practically the race was over. Bayardo led round the bend, sweeping on with effortless ease. Sea Sick was by no means done with. He still galloped steadily on without the least sign of flagging ; Bachelor's Double evoked profound amazement by sticking resolutely to the Frenchman, and for the matter of that we had seen on Wednesday what speed the Irishman possessed.

But their endeavours to live with Bayardo were really absurd. It had been asked whether he could stay. Here he was, after going over two miles in time which misses the Cup record by the fraction of a second, striding out as freely and freshly as if the race were just beginning. But oh! why has Maher done such cruel injustice to the horse and allowed such a totally false view of him to gain currency? His refusals to go to the post at Newmarket, more than once obliging his jockey to take him round by the 


\section{GALICIA : HER FORBEARS}

back of the stands, were put down to an idea that he "did not like racing." Last year we saw how Maher jammed him into the heels of other horses. He looked so magnificent at Ascot that it seemed folly to back anything else to beat him, and I had previously expressed a conviction that he would win for reasons which I gave-a defeat would do him much more harm than a victory (an ordinary win, not such a splendid achievement as we witnessed) would do him good, and he would never be allowed to start unless no doubt were felt about his being at his best and certainly able to get the course. That it is excessively difficult to make sure of this last fact at home I have admitted; but in that respect Alec Taylor seems to get at the truth as his father did before him. The record of Manton in longdistance races has been extraordinarily good, and this season the Chester Cup, Ascot Stakes, the Northumberland Plate, and above all the Gold Cup, have to be added to the long list. It is certain that Bayardo is now regarded in a way vastly different from that which obtained before Ascot. "I didn't quite like the style in which he won his race at Newmarket," some one said to me in the paddock on Thursday, just before the Cup. "Why, surely he beat Great Peter easily enough?" I replied; and his answer 


\section{AND HER OFFSPRING}

was a hesitating "Yes-I suppose he did." The Chester race did want a deal of explaining away. Every one will now most readily accord Bayardo a place among the very best known in the history of the Turf.

So I wrote when the impression was fresh on me, and now to resume once more.

Bayardo's next engagement was in the Dullingham Plate at the Newmarket Second July Meeting, and Mr. Fairie thought that he might as well annex it, as he did with sufficient ease.

Newmarket, I 9 IO.

Dullingham Plate of $£ \mathrm{IOOO}$, of which second received $£_{1} 00$ and third $£_{50}$; by subscription of $£_{20}$, or $£_{5}$ if declared, with $£_{5} 15$ added; for three-year-olds and upwards. Suffolk Stakes Course, one mile and a half.

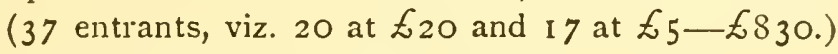
Mr. Fairie's Bayardo, by Bay Ronald,
4 yrs., IO st. $8 \mathrm{lb}$.
D. Maher I

Duke of Portland's The Spaniard, 3 yrs., 7 st. I $2 \mathrm{lb}$.
C. Trigg

Mr. W. Hall Walker's Royal Realm, 5 yrs., Io st. I lb. . . . Wm. Griggs 3 Mr. H. S. Gray's Gog, 3 yrs., 8 st. I lb. F. Wells o Mr. P. Nelke's Lagos, 5 yrs., I o st. 6 lb. B. Dillon o Mr. C. S. Donnelly's Buckwheat, 4 yrs., IO st. 4 lb. . . . . W. Saxby O Betting.-8 to I on Bayardo, I oo to 6 against Royal Realm, 20 to I The Spaniard, 50 to I each Lagos and Buckwheat, 500 to I Gog. Won by a length; five lengths second and third. 


\section{GALICIA : HER FORBEARS}

He was not sent to Liverpool for the Atlantic Stakes in which he had been engaged, it being settled that his next race should be the Goodwood Cup; and this was a tragedy. It is natural that the history of racing should contain few instances of horses who have been beaten with odds of 20 to $\mathrm{I}$ on them. In such a case, as a matter of course, the affair looks an absolutely foregone conclusion; on the other hand, what is called the "glorious uncertainty" of racing at times leads to the most amazing results, as it did here.

Goodwood, I 9 IO.

Goodwood Cup of $£ 1000$ ( $50 \mathrm{gs}$. of which was in plate), with a Sweepstakes of $£ 20$ each, h. ft. (to fund); second received $£_{200}$ and third $£_{\mathrm{I} O 0}$ out of the stakes; for three-year-olds and upwards. Two and a half miles. (33 entrants-£740.) By permission of the Stewards of the Jockey Club the starting gate was dispensed with for this race.

Mr. H. E. Beddington's Magic, by

Martagon, 3 yrs., 7 st. 2 lb. . F. Rickaby, jun. I Mr. Fairie's Bayardo, 4 yrs., 9 st. Io lb. .
D. Maher
2

Mr. J. A. de Rothschild's Bud, 3 yrs.,

7 st. 4 lb. . . . F. Fox

Betting.-20 to I on Bayardo, 20 to I against Magic. Won by a neck; bad third.

It seemed as if there could be no occasion for Bayardo to gallop. Magic had not run as a twoI 14 


\section{AND HER OFFSPRING}

year-old and as a three had done little. He had, indeed, finished second, beaten only a head, for the Wood Ditton Stakes at the Newmarket Craven Meeting; but the winner, a moderate animal, Rock Lane, was giving him $5 \mathrm{lb}$. In the Gold Vase at Ascot he had by no means distinguished himself, and the idea that he had the faintest chance of beating Bayardo appeared altogether too preposterous to be for a moment entertained. Mr. Beddington had told me that he was not altogether without hope, but as for this, an owner is frequently apt wildly to exaggerate the capacity of his horse. Weight-for-age over two miles and five furlongs in July is barely $20 \mathrm{lb}$. : at two miles it is $18 \mathrm{lb}$, at three miles 2 I lb. Here it will be seen Magic was in receipt of $36 \mathrm{lb}$., but this in no way altered the practically universal opinion as to the chance of the younger colt. After the race it occurred to some of the critics that Bayardo was not looking himself; before the start this opinion was not heard. Magic never won afterwards, and truly his career was a strange one-to have taken a single race and that from Bayardo! It was the last appearance of Mr. Fairie's champion, a summary of whose achievements may be given. 


\section{GALICIA : HER FORBEARS}

As a Two-Year-Old.

The New Stakes, Ascot

The National Breeders' Produce Stakes, Sandown

The Richmond Stakes, Goodwood .

The Buckenham Stakes, Newmarket

The Rous Memorial Stakes

The Middle Park Plate

The Dewhurst Plate.

$£$ I,8 17 Iо 0

\begin{tabular}{|c|c|}
\hline 4,357 & 0 \\
\hline 652 & o \\
\hline 1,500 & 0 \\
\hline 730 & 0 \\
\hline 2,505 & 0 \\
\hline I, 477 & 0 \\
\hline
\end{tabular}

As a Three-Year-Old.

The Two Thousand Guineas

The Derby

The Prince of Wales's Stakes, Ascot . 2, I 500

The Sandringham Foal Stakes, Sandown 1,72400

The Eclipse Stakes . . . . 8,870 ० 0

The Duchess of York Plate, Hurst Park $9790 \quad 0$

The St. Leger . . . . . 6,450 o 0

The Doncaster Stakes . . . 47500

The Champion Stakes, Newmarket . 90000

The Lowther Stakes. . . . 47000

The Sandown Foal Stakes . . . I,724 o 0

The Limekiln Stakes . . . . 4250

The Liverpool St. Leger . . . 630 o 0

$£ 24,797 \quad 0 \quad 0$ 


\section{AND HER OFFSPRING}

As a Four-Year-Old.

The Goodwood Cup

The Newmarket Biennial

$57310 \quad 0$

The Chester Vase

The Ascot Cup .

The Dullingham Plate.

I,595 O O

$3,700 \quad 0 \quad 0$

83000

$£ 6,698$ 우

The total of Bayardo's winnings therefore amounted to $£ 44,534$.

What a horse accumulates in stakes is no test of his merits. There are three who have exceeded Bayardo's aggregate-the late Colonel Harry $M$ 'Calmont's Isinglass is first with $£ 57,185$, the Duke of Portland's Donovan follows with $£ 54,935$, and then comes the late Sir James Miller's Rock Sand with $\swarrow_{45}, 6$ r8. It is impossible to judge the relative value of the victories of horses who never came together directly or collaterally, who were separated from each other by periods of years. I have always strongly entertained the idea that Bayardo was certainly a far better animal than Rock Sand, basing the conviction to a great extent on the fact that Rock Sand showed himself a long way inferior to Sceptre and to Ard Patrick. Suggestions have been made to explain Bayardo's defeats in the Two Thousand Guineas and the Derby. As 


\section{GALICIA : HER FORBEARS}

regards the Goodwood Cup, his third failure in the twenty-five races for which he started, it can only be said that the form was manifestly altogether wrong.

When Bayardo was at the height of his fame I asked Mr. Fairie one day how he came to name the horse, and he kindly sent me the explanation which I have thought it interesting to reproduce in facsimile. 
Buymdo was the famrus etud if Pinaldo the thruve, who was one Mthaslemagni Seladimit. concin to Oslando. He mas miginaly found hy thalejifi. the wysard, in a cure guarded hy a drajor which the loijasa Sluw a handed him orer to Amadis de faul. Bayusto's leafo near Sleaford coneicts of etores so yaudo apart thas Anid that Rinalds was sideng on his favourite steed when the demow of the aluee ofmany nfs hehind him, hut the Animal

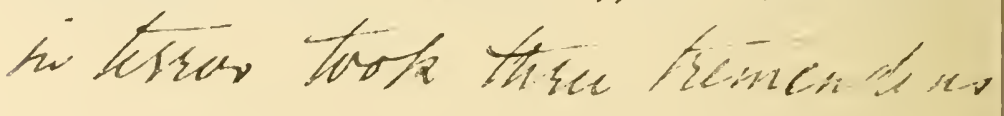


leaper ankrsud. tha fundt. Bapando

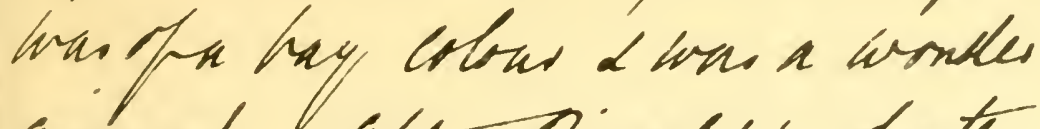
aminul. Heter Rinalds's teath he eceapect sonld heres be cought afain thongh nany sternfats wose male tho es a caflorwasds it aso lonidend luevery of tee the true. the is sufalasent of the still alive. at the surnores fors that he has hew suw on Reveral meecion. at ravirn past of the Coanton. a that conce of the fraver of.

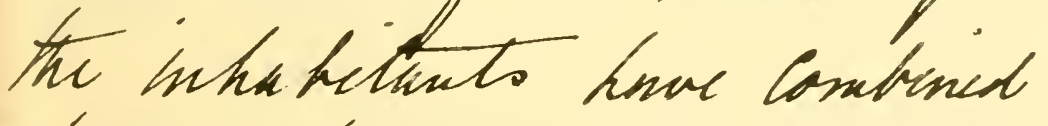
togetter to cateh him buthowe Ro for failed; alas its sepnta that a' Clemon' honousides him how witherane. Seymito leeves

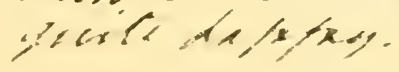





\section{AND HER OFFSPRING}

\section{CHAPTER IV}

\section{LEMBERG}

Is the year 1906 Galicia was sent to Cyllene, then standing at a fee of roo guineas, which was increased to 300 guineas the following year, and the result was Lemberg, bay like his half-brother, a decidedly handsome colt when later on his make and shape developed, but perhaps somewhat deficient in the peculiarly high quality which distinguished Bayardo. It was early ascertained that Lemberg could gallop. He was tried on the 8 th June as follows :

Lemberg, 2 yrs., 8 st. 8 lb. . . . Clark I Benwhat, 4 yrs., 8 st. 3 lb. . . . . Hulse 2 Seedcake, 4 yrs., 8 st. 8 lb. . . . . Toon 3 Maid of Corinth, 2 yrs., 8 st. 7 lb. . . Ault o Won easily by a length and a half; three lengths between second and third.

Here, it will be perceived again, the trial was not a high one. Sir William Bass's Benwhat was a bad animal. I think he never won more than a single little $\oint_{\text {I }}$ oo race. Once he was second to an extremely moderate three-year-old who gave him $3^{2}$ lb. and a year. Seedcake had 


\section{GALICIA : HER FORBEARS}

failed to win anything since he tried Bayardo twelve months previously. Maid of Corinth, the superbly bred daughter of Cyllene and Sceptre, had not run : she was to win two races later and to be twice second.

Fortunately a programme had been mapped out for Lemberg to a great extent following the lines along which the elder had travelled to fame. His first appearance was made in the New Stakes at Ascot, no more than 2 to I being offered against him in a field of twelve; against Bayardo, as we have seen, 7 to I was laid. A son of Sundridge, not at the time named, afterwards called Sunningdale, running as the Sweet Story colt, was almost in equal demand with Lemberg, the returned odds being 5 to 2 . The idea that there was anything like equality between them was speedily dispelled; here Sunningdale finished third, four lengths behind Catrail, one of Mr. Leopold de Rothschild's breeding, by St. Frusquin-Catkin, who never rose to the first rank.

\section{Ascot, 1909 .}

NEw Stakes of $£$ Io each, with $£$ rooo added, of which second received 10 per cent. and third 5 per cent.; for two-year-olds. Five furlongs. (I 38 entrants$£ 2013$.

Mr. Fairie's Lemberg, by Cyllene, 8 st.

Io $\mathrm{lb}$.

B. Dillon 


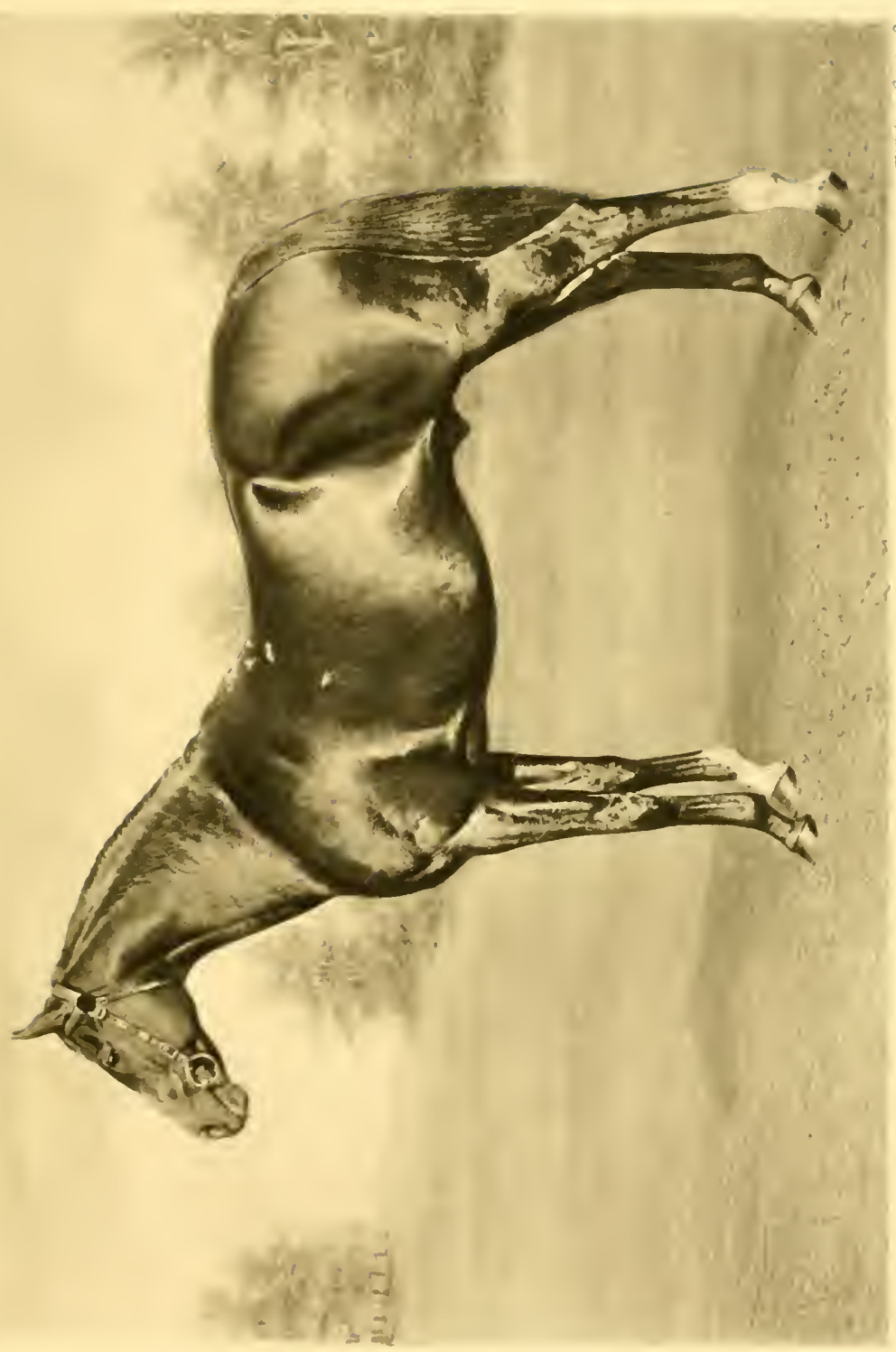

$\frac{2}{2}$ 



\section{AND HER OFFSPRING}

Mr. Leopold de Rothschild's Catrail,

8 st. Io lb. . . .

Mr. J. B. Joel's ch. c. by Sundridge-

Sweet Story, 8 st. Io lb. . . Walt. Griggs 3

Sir E. Cassel's Conte d'Hoffmann,

8 st. Io lb. . . . W. Halsey o

Lord Derby's Decision, 8 st. I o lb. . D. Maher o

Mr. Sol Joel's Sunder, 8 st. Io lb. . F. Wootton o

Mr. J. W. Larnach's ch. c. by Jeddah-

Game Hen, 8 st. io lb. . . A. Templeman o

Mr. D. M'Calmont's Counterpoise, 8 st.

Io lb. . . . . . S. Donoghue o

Mr. Barclay Walker's Lawrenny, 8 st.

Io lb. . . . C. Heckford O

Lord Ebury's Dumella, 8 st. io lb. . H. Randall O

Mr. E. de St. Alary's Photime, 8 st.

7 lb. . . . . Wm. Griggs o

Mr. W. Hall Walker's Lily Rose, 8 st.

7 lb. . . . . B. Lynham o

Betting.-2 to I against Lemberg, 5 to 2 Sweet Story c., 6 to I Decision, Io to I Sunder, 100 to 9 Lawrenny. Won by one and a half lengths; four lengths second and third. Decision whipped round when the barrier went up.

It will be seen that Lemberg won by a length and a half, precisely as Bayardo had done, and no sort of doubt existed that Mr. Fairie had found another good one. It seems strange that Lemberg should have been omitted from the National Breeders' Produce Stakes at Sandown. For this Mr. Fairie had only nominated one, King Midas, a son of Persimmon and Bona 


\section{GALICIA : HER FORBEARS}

Dea, who was never more than a useful animal. Lemberg was in the Chesterfield Stakes, however, at the Newmarket Second July, and for that he ran.

Newmarket, I 909 .

Chesterfield Stakes of $£_{30}$ each, $20 \mathrm{ft}$., of which second received $£ \mathrm{IOO}$, third saved stake; for twoyear-olds. Chesterfield Course, last five furlongs of B.M. (43 entrants- $£ 750$.)

Mr. Fairie's Lemberg, by Cyllene, 9 st. 3 lb. . . . . . . D. Maher I Mr. Leopold de Rothschild's Catrail, 8 st. Io lb. . . . . . O. Madden 2 Mr. A. F. Basset's Prince Rupert, 9 st. 3 lb W. Saxby 3 Mr. L. Neumann's Gallifet, 8 st. Io 1b. . W. Smith o Lady de Bathe's Jeton, 8 st. ro lb. . . F. Fox o

Betting.-2 to I on Lemberg, 4 to 1 against Prince Rupert, 6 to I Catrail. Won by two lengths; one and a half lengths second and third.

That 2 to I was laid on Lemberg affords evidence of the manner in which he had won at Ascot. Neither he nor Catrail had been out again prior to this Newmarket race, but though Catrail was receiving $7 \mathrm{lb}$. he was not supposed to have anything like a real chance. Mr. A. F. Basset's Prince Rupert was a colt of some pretensions. He had won the July Stakes at the previous Newmarket Meeting, and intermediately 


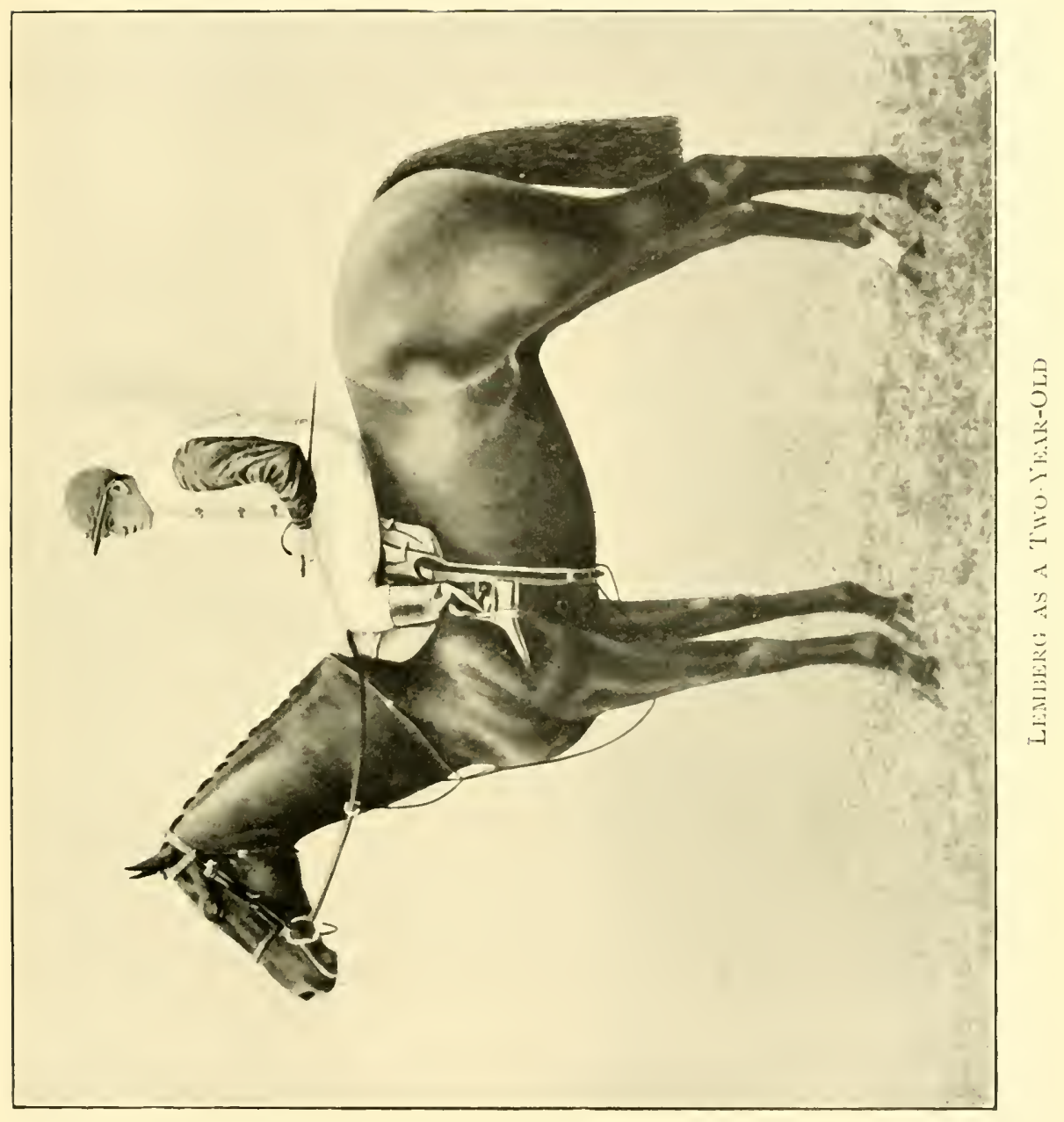





\section{AND HER OFFSPRING}

the Champagne Stakes at the Bibury Club Meeting at Salisbury.

Lemberg went to Goodwood as his brother had done, running, however, for the Rous Memorial instead of for the Richmond Stakes. When odds of 6 to $\mathrm{I}$ are laid on a horse every one understands what it means.

Goodwood, I 909.

Rous Memorial Stakes of $£ 20$ each, h. ft. for acceptors, with $£_{500}$ added for owner and $£_{1}$ oo for nominator of winner; second received $£$ Ioo out of stakes; for two-year-olds ; entrance $£_{5}$, only $\mathrm{ft}$. if declared, these $\mathrm{fts}$. being added to the Rous Memorial Fund. T.Y.C., six furlongs. (79 entrants, ft. declared for $18-£$ I I 25 .)

Mr. Fairie's Lemberg, by Cyllene, 9 st. $6 \mathrm{lb}$

D. Maher I

Mr. W. Hall Walker's Lily Rose, 8 st.
2 lb. (car. 8 st. 3 lb.)
B. Lynham

Mr. Ernest Dresden's Gally Bawn, 8 st. 2 lb.

Walt. Griggs 3

Captain Forester's b. c. by Cupbearer-

Lady Drake, 8 st. 5 lb. . . W. Saxby o

Betting.-6 to I on Lemberg, 7 to I against Gally Bawn. Won by three lengths; head second and third.

Gally Bawn, the only one whose success was conceived possible, was not altogether without form. She had won her two previous races, the second of them, the Plantation Plate at Newmarket, in a field of twenty-three, and Colonel 


\section{GALICIA : HER FORBEARS}

Hall Walker's Lily Rose, to whom it will be seen Lemberg was giving a stone more than weightfor-age, was an animal of some capacity, for on the occasion of her next outing she won the Gimcrack Stakes, a race for which Mr. Fairie is not accustomed to enter, possibly-though as to this I am only guessing-from a disinclination to undertake a penalty of success, the making of a speech at the annual dinner of the Gimcrack Club.

Lemberg was next sent to Doncaster for the Champagne Stakes, and the betting on this race tends again to prove what was thought of him. All his three opponents were good winners, Lord Rosebery's Neil Gow, indeed, had taken the National Breeders' Produce Stakes at Sandown after getting badly away in easy fashion by four lengths ; Major Eustace Loder's Admiral Hawke, an own brother to the famous Pretty Polly, had carried off the Chesterfield Stakes at Newmarket and the Lavant at Goodwood; Mr. H. P. Whitney's Whisk Broom, accepted as one of the best colts who has ever come from America, had easily secured the Prince of Wales's Plate at York. That odds of 15 to 8 should have been laid on Lemberg against such opponents is certainly a testimony to character; but this was to be his one failure in his first season. 


\section{AND HER OFFSPRING}

Doncaster, I 909:

Champagne Stakes of $£_{30}$ each, $20 \mathrm{ft}$., or $£_{5}$ (to fund) if declared, with $£$ I ooo added, of which second received $£_{\mathrm{I} O 0}$ and third $£_{50}$; for two-year-olds. Red House in, 5 furlongs 152 yards. (I I 4 entrants, ft. declared for $78-£$ I 590 .)

Lord Rosebery's Neil Gow, by Marco, 9 st. $\dot{2}$ Eustace Loder's Admiral Hawke, 9 st. . . . . . B. Dillon 2 Mr. Fairie's Lemberg, 9 st. • . H. Jones 3 Mr. H. P. Whitney's Whisk Broom, 9 st. J. H. Martin o

Betting. - I 5 to 8 on Lemberg, 6 to I against Admiral Hawke and Neil Gow, 7 to I Whisk Broom. Won by one and a half lengths; length second and third.

It was afterwards demonstrated that between Lemberg and Neil Gow there was practically nothing to choose; here Lord Rosebery's colt beat him by two lengths and a half, form which was unquestionably wrong, and what added stronger proof of this was the position of Admiral Hawke, whom no one would rank with the son of Galicia. Lemberg's last three races were precisely the same as those which Bayardo had taken. In the Rous Memorial at the Newmarket First October, Bayardo had met one altogether unworthy antagonist; Lemberg was not to have quite so easy a task. 


\section{GALICIA : HER FORBEARS}

Newmarket, I 909.

Rous Memorial Stakes of $£$ I 5 each, io ft. for acceptors, with $£ 500$ added for owner and $£ 100$ for nominator of winner; for two-year-olds; second received $£_{50}$ out of stakes; entrance $£_{5}$, only ft. if declared. Rous Course, five furlongs. (59 entrants, ft. declared for 23- £920.) The Rous Memorial Fund received 20 per cent. of the value of the race, after calculating under Rule I 7 .

Mr. Fairie's Lemberg, by Cyllene, 9 st. $3 \mathrm{lb}$.

Lord Durham's Rochester, 8 st. I o lb. . Mr. P. Nelke's Yellow Slave, 8 st.

Mr. J. H. Houldsworth's Cedrus, 8 st. Io lb. . . . . B. Lynham o Mr. L. Neumann's Gallifet, 8 st. io lb. Walt. Griggs o Mr. Leopold de Rothschild's Catrail, 8 st. Io $1 \mathrm{~b}$.

B. Dillon I

D. Maher 2

W. Saxby 3

Betting.- 2 to I on Lemberg, 3 to I against Yellow Slave, I 00 to 7 Catrail. Won by a neck; three lengths second and third.

Lord Durham's Rochester, a son of Rock Sand and Caparison, had been talked about for some time previously, though the betting does not indicate any fancy for him, notwithstanding that Maher was riding. Mr. Nelke's Yellow Slave had shown herself a smart filly, having won four of the six races for which she had been out and finished second in the other two; but she gave Lemberg no trouble. As for Rochester, 


\section{AND HER OFFSPRING}

this was his only race as a two-year-old. He won the Column Produce Stakes by half a dozen lengths at his next appearance, as a threeyear-old, but was only out twice more during that season, his trainer finding it impossible to get him quite right.

Whisk Broom had been going on so remarkably well in the autumn that Joyner, his really accomplished trainer, was not without some hope of winning the Middle Park Plate; and the American colt by no means disgraced himself.

Newmarket, I 909.

Middle Park Plate of $£$ I OoO, added to a Sweepstakes of $£_{30}$ each, $20 \mathrm{ft}$., of which second received $£_{200}$ and third $£_{\mathrm{I} O \mathrm{O}}$; for two-year-olds; entrance $£_{50}$. Bretby Stakes Course, six furlongs. (I I 4 entrants $-£_{302}$.)

Mr. Fairie's Lemberg, by Cyllene, 9 st.
3 lb.
D. Maher I

Mr. H. P. Whitney's Whisk Broom, 9 st. J. H. Martin 2 Major Eustace Loder's Admiral Hawke, 9 st. 3 lb. .
B. Dillon 3

Duke of Portland's Merry Jack, 9 st. $3 \mathrm{lb}$.
W. Earl

Mr. J. B. Joel's Pasquita, 9 st.

Mr. J. W. Larnach's ch. c. by Jeddah-

Game Hen, 8 st. Io lb.

Walt. Griggs o

Mr. J. B. Thorneycroft's Sloanston, 8 st.

Io lb. . . . . J. Williamson o

Mr. L. Neumann's Moyglare, 8 st. 7 lb. F. Wootton o Betting. -7 to 4 against Lemberg, 7 to 2 Whisk I 27 


\section{GALICIA : HER FORBEARS}

Broom, 4 to I Admiral Hawke, 7 to I Moyglare, I oo to 8 Merry Jack. Won by a neck; three-quarters of a length second and third.

Maher was, however, again riding Lemberg, as he had done in the Chesterfield Stakes and at Goodwood, whenever, indeed, he was not claimed by Lord Rosebery or any other owner who had secured his services, and though winning by a neck is not without a distinct element of risk, especially on the wide Newmarket course, there is no doubt that the distance by which he beat Whisk Broom could have been greatly augmented. This was, in fact, shown unmistakably in the Dewhurst Plate.

Dewhurst Plate, for two-year-olds. fi 527.

Seven furlongs.

Mr. Fairie's Lemberg, 9 st. 5 lb. . . Maher

I

Mr. H. P. Whitney's Whisk Broom,

8 st. 13 lb. . . . . J. H. Martin 2

Betting.-I I to 4 on Lemberg. Won by five lengths. I minute $3 \mathrm{I}_{5}^{4}$ seconds.

It will be observed that here Lemberg was giving $6 \mathrm{lb}$. instead of $3 \mathrm{lb}$. as in the Middle Park Plate, and the neck in the former race was now extended to five lengths. The Champagne Stakes had marred what would otherwise have been a record of complete success.

Lemberg's first appearance as a three-yearI 28 


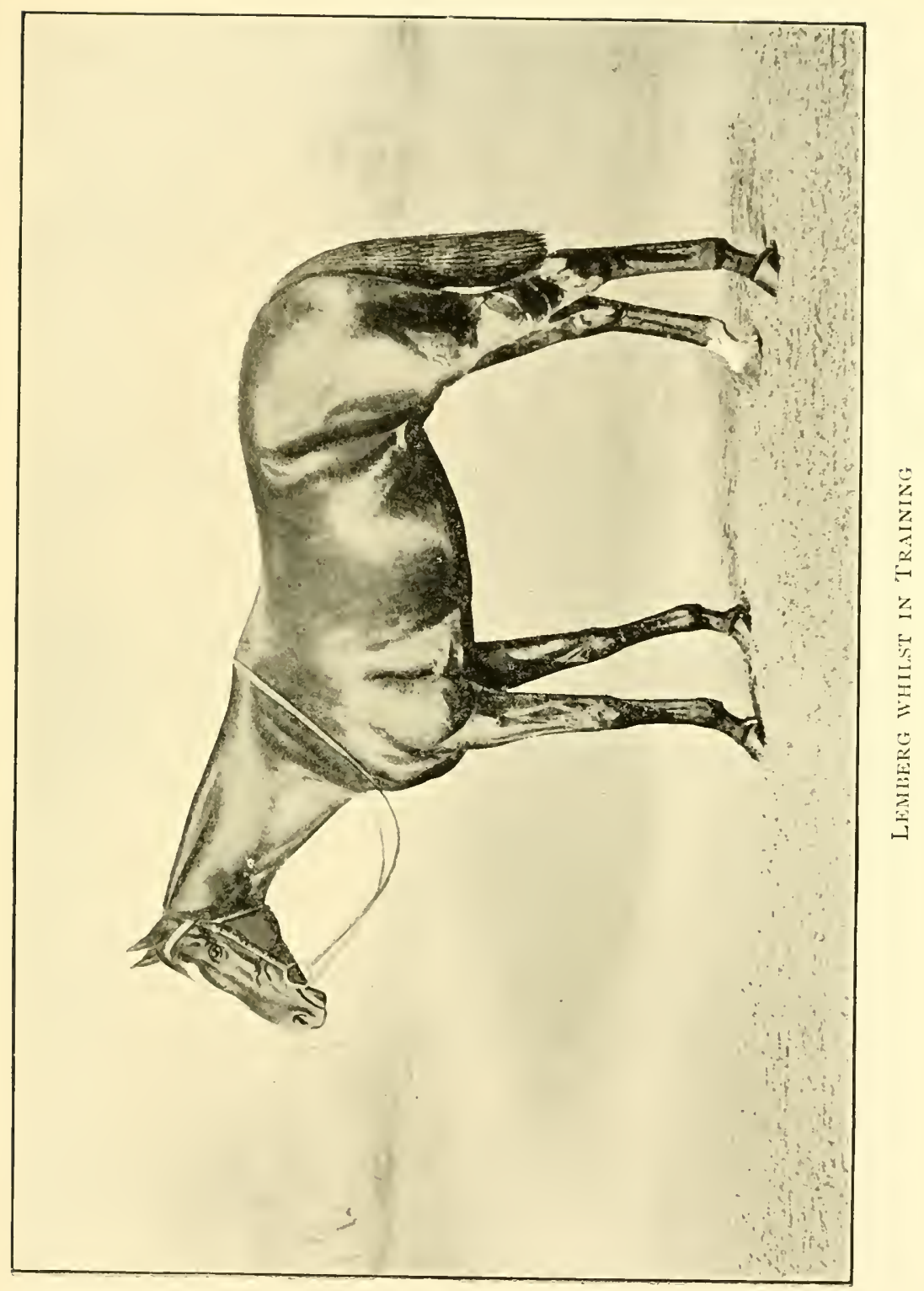





\section{AND HER OFFSPRING}

old was made in the Two Thousand Guineas, a race for which there have frequently been sensationally close finishes; and this was to be another. Partly because Neil Gow had already been out and had easily won the Craven Stakes, partly because he was ridden by Maher, he started a better favourite than Lemberg. The finish was, however, considerably closer than the betting indicated.

Newmarket, I 9 I o.

Two Thousand Guineas Stakes of $£ \mathrm{I} O 0$ each, h. ft., for entire colts and fillies, foaled in 1907 ; colts 9 st., fillies 8 st. 9 lb.; second received $£ 400$ and third $£ 200$ out of stakes. R.M. (I 25 entrants- $£ 6200$.)

Lord Rosebery's ch. c. Neil Gow, by Marco, 9 st. . . . . D. Maher I

Mr. Fairie's b. c. Lemberg, 9 st. . . B. Dillon 2 Mr. H. P. Whitney's ch. c. Whisk Broom, 9 st.

Major Eustace Loder's ch. c. Admiral Hawke, 9 st. . . . . W. Saxby o Mr. J. Buchanan's b. c. Tressady, 9 st. . W. Higgs o Mr. W. M. Cazalet's b. c. San Antonio, 9 st.

Lord Durham's b. c. Rochester, 9 st. Capt. F. Forester's b. c. Placidus, 9 st. . Mr. J. A. de Rothschild's ch. c. Bronzino, 9 st.

Mr. J. A. de Rothschild's br. c. Nankeen, 9 st.

Sir R. W. B. Jardine's br. c. Sanctuary, 9 st.

J. H. Martin 3

H. Jones o

H. Randall o

G. Stern O M. Henry o F. Fox

- Wm. Griggs o 


\section{GALICIA : HER FORBEARS}

Mr. G. A. Prentice's ch. c. Montreal, 9 st. R. Keeble o Mr. St. Aubyn's b. c. Cardinal Beaufort,

9 st.

C. Trigg

Betting.-2 to 1 against Neil Gow, 7 to 2 Lemberg, 6 to I Tressady, Ioo to 8 Rochester, Ioo to 7 Admiral Hawke and Whisk Broom, 100 to 6 Placidus, 25 to I Sanctuary and San Antonio. Won by a short head; two lengths second and third.

The two horses were very close together, so much so that Dillon was unable to use his whip in his right hand, and at any rate an idea existed that Mr. Fairie's colt was somewhat unlucky to have been beaten, that the result would have been different had the jockeys been reversed, which may or may not have been the case. The chief result of the struggle was to add interest to the coming Derby, and there was a rough gallop -Alec Taylor employs this term instead of describing it as a trial-at Manton on the 28th of May, the distance a mile and three-quarters, not the mile and a half that might have been expected :

Lemberg, 3 yrs., 8 st. I lb. . . . Rose I Maid of Corinth, 3 yrs., 8 st. 5 lb. . . Mildenhall 2 Rosedrop, 3 yrs., 8 st. 5 lb. . . . Murray 3 Bayardo, 4 yrs., 9 st. 8 lb. . . . Clark 4 Orphah, 5 yrs., 9 st. 8 lb. . . . Baker o

"Lemberg went much the best. Maid of Corinth and Rosedrop, who ran lazily, finished together. Bayardo went with no dash at any 


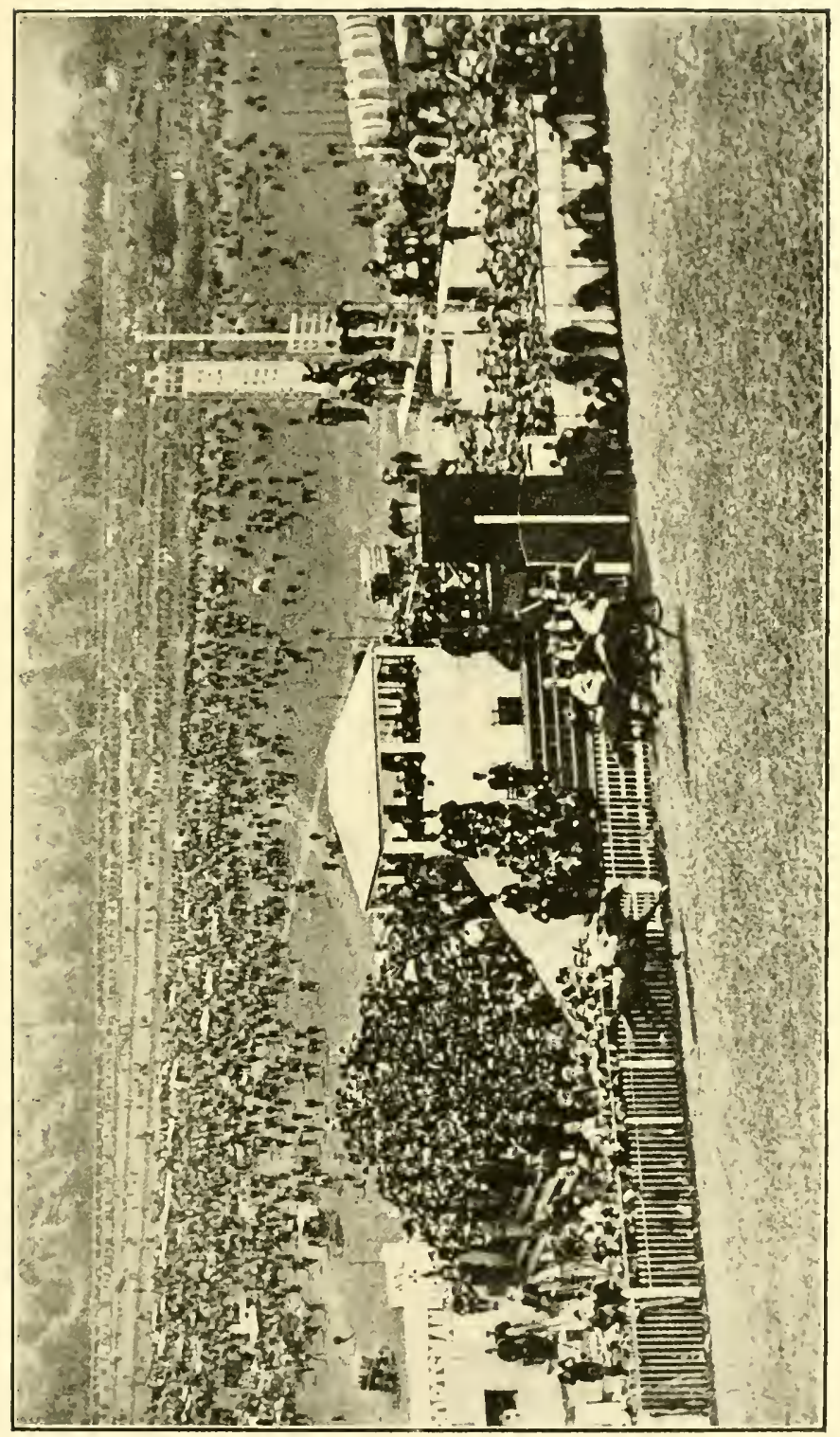

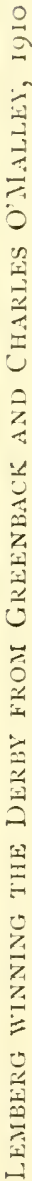





\section{AND HER OFFSPRING}

part of the gallop. Orphah jumped in and brought them along the last seven furlongs, finishing second." It will be understood that he is not placed there in the record as he was not in the spin all the way. It is not a little surprising to find the fillies giving Lemberg weight. $\mathrm{He}$ and Bayardo, it will be observed, were running at exactly weight for age.

Neither Lemberg nor Neil Gow was out between their Newmarket struggle and Epsom, where the betting on the Derby certainly suggested that the Two Thousand was considered anything but a trustworthy guide. There were rumours to the effect that Neil Gow had not been doing particularly well in the brief interval between the races, but he was firm in the market at I I to 4 ; a great many of his backers were, in fact, content to take less, and it may safely be assumed that there was not much the matter with him, nor indeed was he far off at the finish. Lord Villiers' Greenback in getting to Lemberg's neck did much better than there had seemed reason to anticipate. He had won the March Stakes a few weeks before, and his two-year-old performances had been unmistakably good: he was out ten times, won six of his races and was second for three of the others; but his victories had not been in the stakes which raise their winners 


\section{GALICIA : HER FORBEARS}

quite to the front rank, though they had been of sufficient account to bring in $£ 4344$. There was nothing discreditable to Lemberg in being pressed by a colt of that capacity, for Greenback won his next three races, including the Prince of Wales's Stakes at Ascot and the Royal Stakes at Newbury, in which latter he beat Mr. Waldorf Astor's good filly Winkipop by three parts of a length, third, a neck behind, being $\mathrm{Mr}$. C. E. Howard's Willonyx, to whom Greenback was giving I I lb. It must be added, however, that Willonyx was far better as a four-year-old than he had been as a three. One feels, nevertheless, that Greenback was not, as a matter of real merit, within a neck of Lemberg.

\section{Epsom, I910.}

One Hundred and Thirty-first Renewal of the Derby Stakes of $£ 6500$ (including $£ 500$ for nominator of winner), with $£ 400$ for second and $£ 200$ for third, by subscription of $£ 50$ each, h. ft., or $£_{5}$ if declared, with $£ 650$ added ; for three-year-olds, entire colts and fillies; colts 9 st., fillies $8 \mathrm{st} .9 \mathrm{lb}$. About a mile and a half. (37 I entrants, viz. I 5 at $£ 50,195$ at $£ 25$, and $\mathrm{I} 6 \mathrm{I}$ at $£_{5}-£_{6450}$.)

Mr. Fairie's b. c. Lemberg, by Cyllene, 9 st. . . . . B. Dillon I Lord Villier's b. c. Greenback, 9 st. . F. Templeman 2 Mr. A. P. Cunliffe's b. c. Charles O'Malley, 9 st. . . . S. Donoghue 3 Lord Rosebery's ch. c. Neil Gow, 9 st. D. Maher 4 


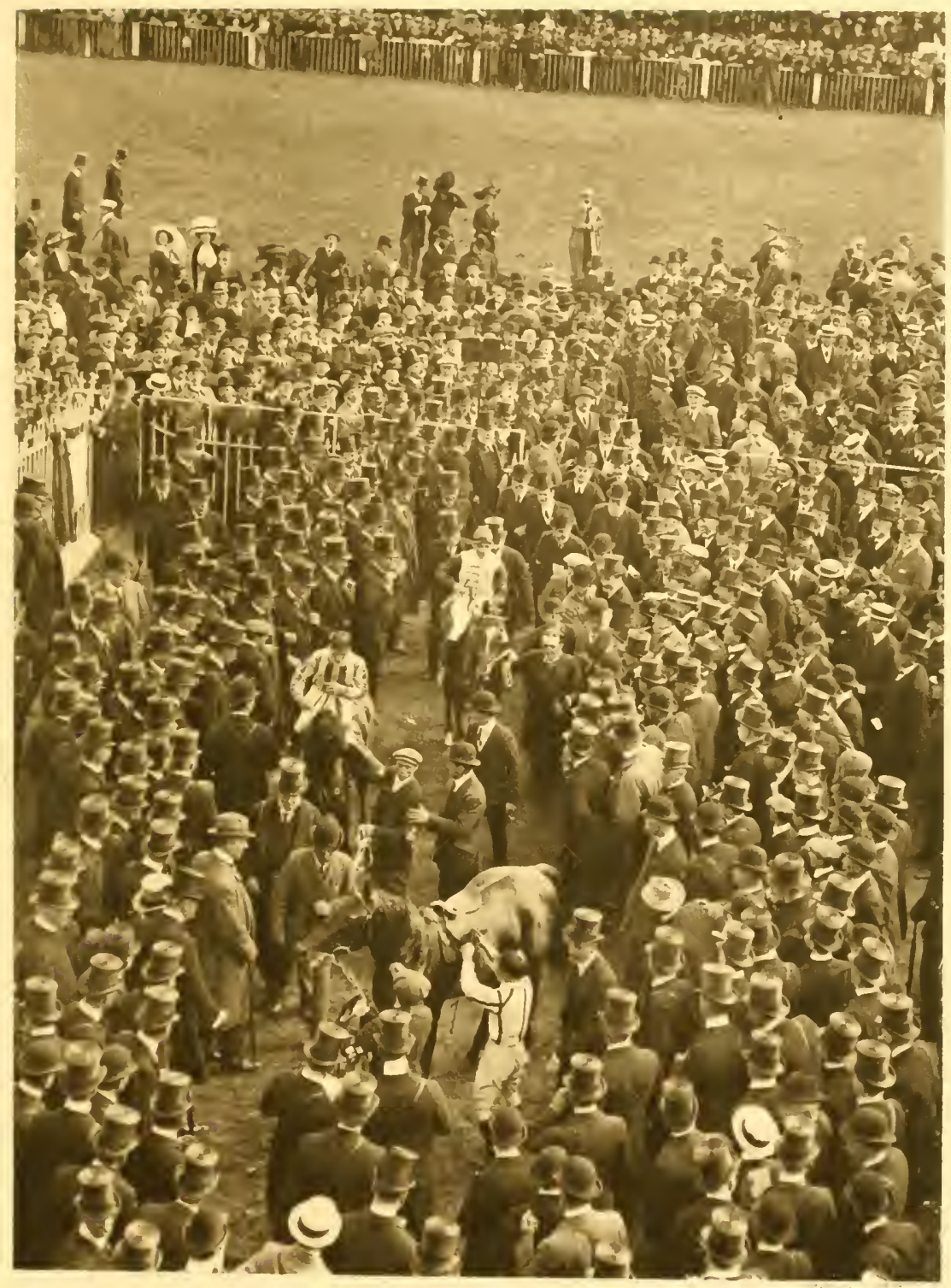

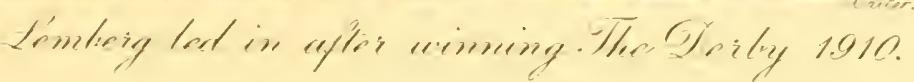





\section{AND HER OFFSPRING}

Mr. W. M. Cazalet's b. c. San Antonio,

9 st. . . . . .

Mr. E. A. Wigan's b. or br. c. Ulster

King, 9 st. . . . . G. Stern o

Mr. St. Aubyn's b. c. Cardinal Beau-

fort, 9 st. . .

Major Eustace Loder's ch. c. Admiral

Hawke, 9 st. . . .

Mr. W. Hall Walker's b. c. Glazebrook, 9 st. . . . . A. Templeman o

Lord Derby's br. c. Swynford, 9 st. . B. Lynham o

Mr. J. J. Bell-Irving's b. or br. c.

Rokeby, 9 st. . . . . Wm. Griggs o

Mr. J. Wallis's ch. c. General Botha,

9 st.

Mr. D. M'Calmont's b. or br. c.

Malpas, 9 st. . . . H. Randall o

Mr. J. B. Joel's b. c. Wildflower II,

9 st. . . . . . Walt. Griggs o

Mr. H. S. Gray's ch. c. Gog, 9 st. . F. Wells o

Betting. -7 to 4 against Lemberg, I I to 4 Neil Gow, I 00 to 8 Admiral Hawke, Ulster King, and Greenback, 33 to I Charles O'Malley, 40 to I Rokeby, 50 to I Swynford and Cardinal Beaufort, 66 to I Glazebrook and Malpas. Won by a neck; two lengths second and third. Cardinal Beaufort dwelt and lost ground at the start. The Stewards called Wells before them to explain his reckless riding, and suspended him for the remainder of the Meeting, and reported him to the Stewards of the Jockey Club. The latter Stewards (Lord Durham acting for Lord Derby) having investigated the case, were of opinion that Wells' reckless riding was not intentional, but they cautioned him strongly as to his future riding. 


\section{GALICIA : HER FORBEARS}

Lemberg went to Ascot. $\mathrm{He}$ had three engagements-the Prince of Wales's Stakes, the St. James's Palace Stakes, and the Fifty-seventh Triennial. The second, of course by far the most valuable, being worth $£ 245^{\circ}$, was chosen, and esteemed so great a certainty that odds of 8 to I on him were laid.

Ascot, 1910.

St. James' Palace Stakes of $£$ roo each, h. ft., with $£_{300}$ added, of which second received $£_{3} 00$; third saved stake; for three-year-olds. Old Mile. (47 entrants- $£ 2450$.)

Mr. Fairie's Lemberg, by Cyllene, 9 st. D. Maher I Mr. A. F. Basset's Prince Rupert, 9 st. H. Randall 2 Lord Derby's Swynford, 8 st. 7 lb. . F. Wootton 3 Mr. Reid Walker's Redwald, 8 st. 7 lb. W. Higgs O Mr. August Belmont's Merry Task, 8 st. 7 lb. . . . H. Watts o Mr. J. B. Joel's b. c. by Ayrshire-Yours, 8 st. 7 lb. . . . Walt. Griggs o

Betting.-8 to I on Lemberg, Io to I against Swynford. Won by three lengths; length second and third.

Afterwards it seemed somewhat strange that this should have been the price, in view of the circumstance that Lord Derby's Swynford was one of the other five runners and in receipt of 7 lb. from Mr. Fairie's colt. The explanation of course is that Swynford was not ready. His first appearance of the season had been in the I 34 


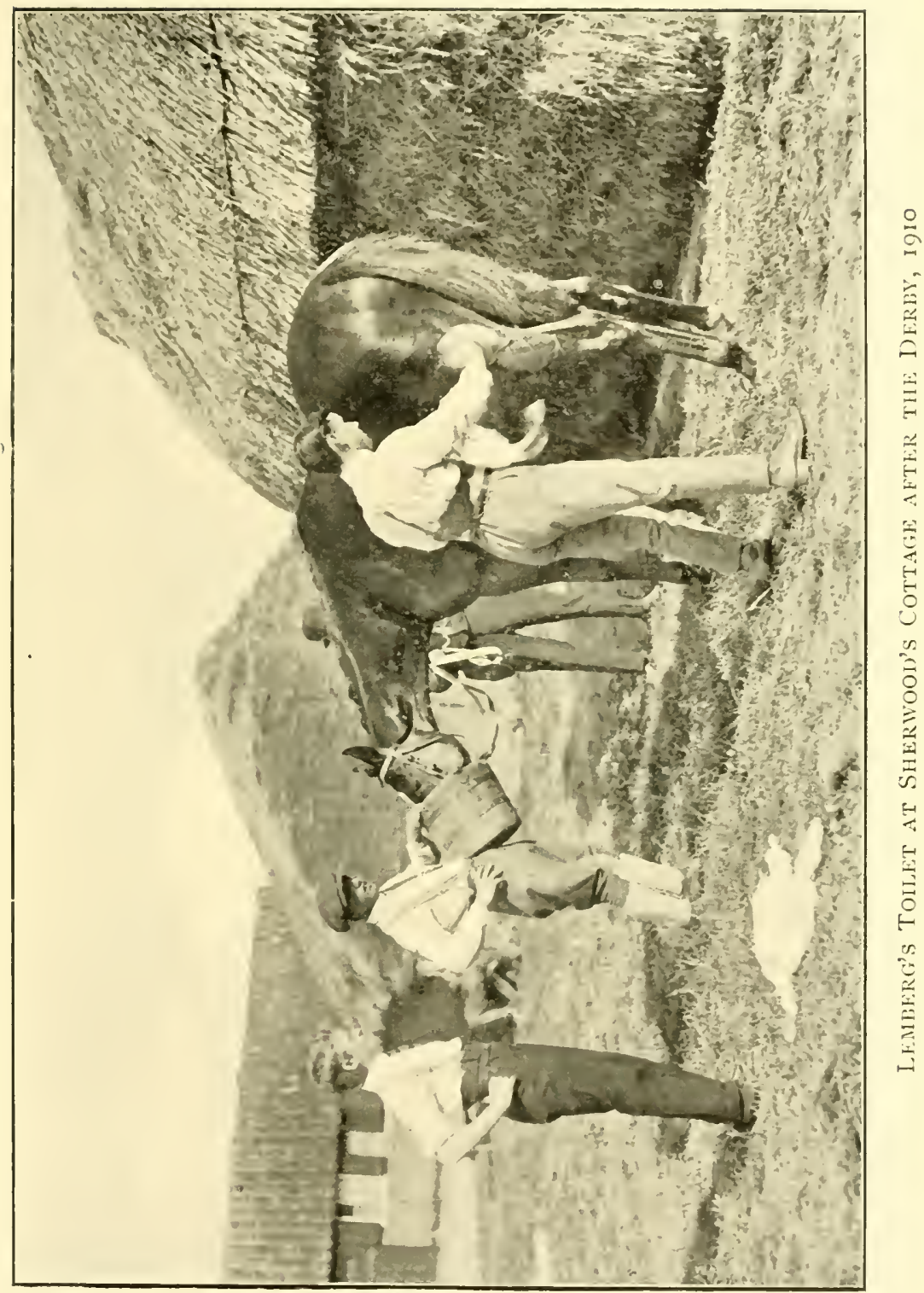





\section{AND HER OFFSPRING}

Derby, when 50 to I was laid against him, and here it will be seen he was not even second.

As regards Lemberg's unfortunate expedition to Paris for the Grand Prix, it can only be said that he did not show anything approaching to his true form. The journey, change of surroundings, \&c., often affect horses adversely, and he must be rated as an example; but I give details.

Paris, I 9 I0.

Grand PRIX DE PARIS of $£$ I 4,406 for owner and $£ 800$ for breeder of winner, $£$ I 200 for owner of second, and $£ 600$ for owner of third; for three-year-olds. One mile seven furlongs.

Nuage, by Simonian, 9 st. 2 lb. . C. Childs I Reinhert, 9 st. 2 lb. . . . O'Neill 2 Bronzino, 9 st. 2 lb. . . . F. Fox 3 Charles O'Malley, 9 st. 2 lb. . . S. Donoghue 4 Lemberg, 9 st. 2 lb. . . . D. Maher 5 Sursis, 9 st. 2 lb. . . . M. Barat o Secours, 9 st. 2 lb. . . . Sharpe o Or du Rhin II, 9 st. 2 lb. . . P. Woodland O Le Platine, 9 st. 2 lb. . . . R. Sauval o Radis Rose, 9 st. 2 lb. . . J. Jennings O Cadet Roussel III, 9 st. 2 lb. . N. Turner O Renard Bleu, 9 st. 2 lb. . . G. Bartholomew o Cockfield, 9 st. 2 lb. . . . M. Henry o La Française, 8 st. I 3 lb. . . Wm. Griggs o Marsa, 8 st. I 3 lb. . . . G. Stern 


\section{GALICIA : HER FORBEARS}

Hunyade, 9 st. 2 lb. . . . Bellhouse 0 Coquille, 8 st. I $3 \mathrm{lb}$. . . G. Clout o

Won easily by three lengths; three-quarters length second and third, half length third and fourth.

Lemberg missed the Sandringham Foal Plate at Sandown, which would have been worth over fizoo, nor was he brought out for the Princess of Wales's Stakes at the Newmarket First July. He was also in the Zetland Stakes at the Second July Meeting, for which small event it was naturally not thought worth while to run him, it having been determined to keep him for the Eclipse, in which he was to meet his old antagonist, Neil Gow. It had been accepted as fact that Lord Rosebery's colt was not himself in the Derby, and in estimating chances at Sandown there was a reversion to the Two Thousand Guineas running, the question being whether, as alleged, Lemberg had suffered from interference when beaten a short head. The general idea that he ought to have won-with little or nothing to spare, doubtless, but still that with fair luck he would just have finished in front-was borne out by the betting on the Eclipse, in which it will be seen that Lemberg was just slightly preferred. Of the others, Placidus, though he had not done much in public, was reported able to do biggish things 


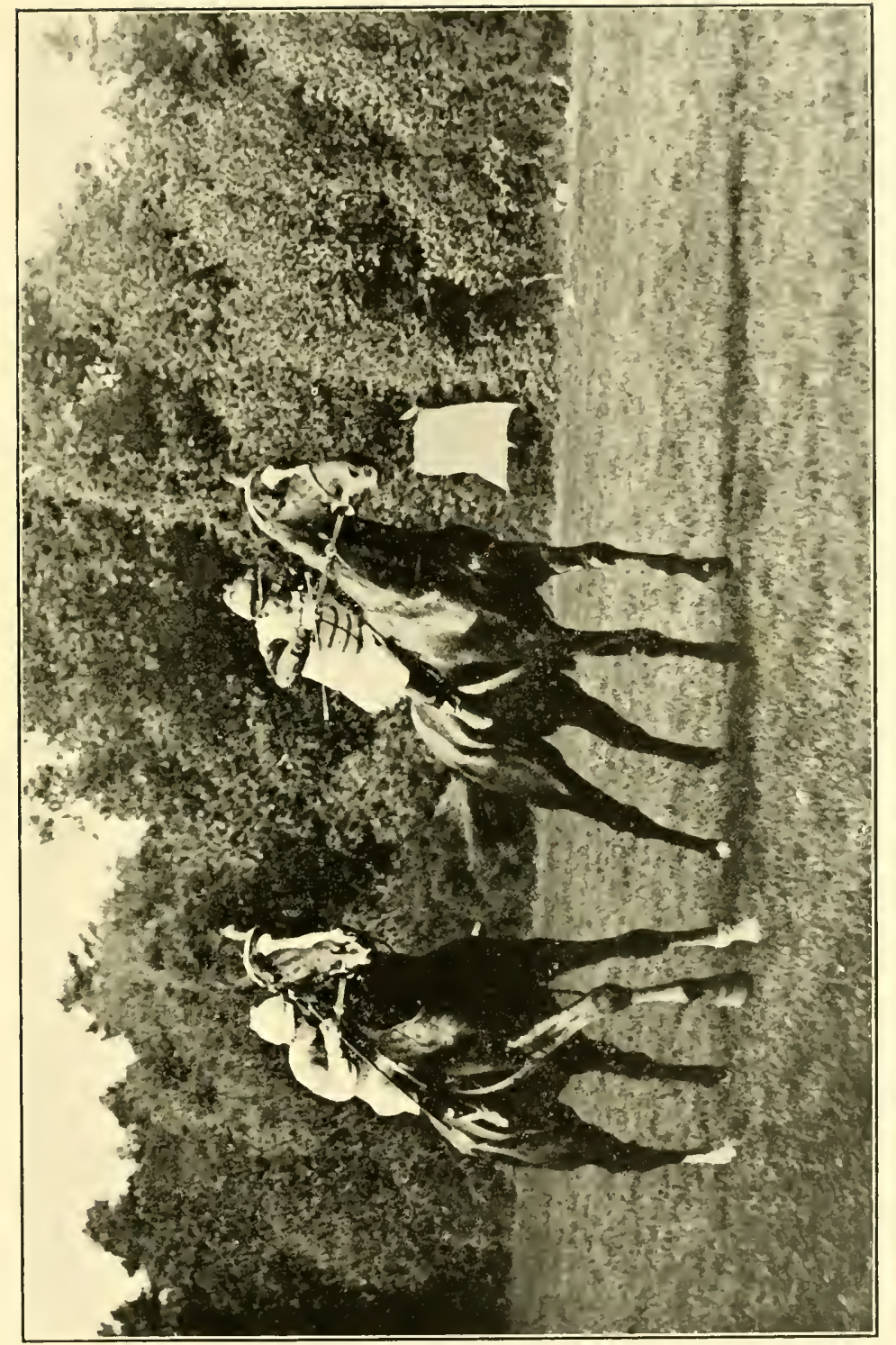

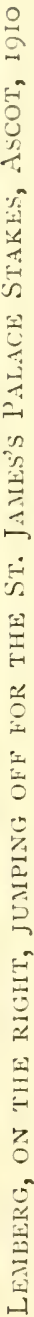





\section{AND HER OFFSPRING}

at home, and he found a certain number of rash supporters in the face of the two favourites.

A great race resulted. Sanguine backers of both Lemberg and Neil Gow persuaded themselves during the moments before the numbers were hoisted that there was a head in favour of the colt on whom their hopes were fixed. Pessimists similarly supposed that the horse in whom they were interested was just beaten. After what seemed an unusually long time the verdict was given - a dead heat, the first in the history of the race, not a very long history, however-though some of the results had been extremely close. Thus Lemberg's name was written below that of his half-brother, but as one of a bracketed pair.

\section{Sandown Park, i 9 I 0.}

Twenty-third Renewal of the Eclipse Stakes of $£_{1} \mathrm{l} 0,000$, of which owner of second received $£ 900$, of third $\mathcal{L}_{115}$, nominator of winner $\mathcal{L}_{500}$, and nominator of second $\ell_{0} \mathrm{IOO}$; by subscription of $\mathcal{L}_{5}$ each for three-year-olds if ft. declared by October 1 3, 1908, or $£$ IO for four-year-olds if declared by March $3 \mathrm{I}$, 1908 ; if left in after those dates a further $\mathcal{E}_{2} \mathrm{I}$ each; if left in after March 30, I 909, a further $£ 34$ for three-year-olds or $\mathcal{L}_{32}$ for four-year-olds; and if left in after January 4, I 910 , a further $£ 55$

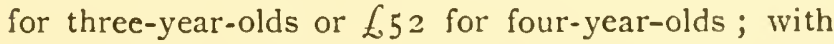
\&i 809 added. Eclipse Stakes Course, one mile and a quarter. (192 entrants, viz. 30 at $\oint_{115}$, I 4 


\section{GALICIA : HER FORBEARS}

at $£ 63,26$ at $£ 60,46$ at $£ 3$ I, I 8 at $£ 26,23$ at $£ 10$, and 35 at $£ 5-£ 8770$.)

Mr. Fairie's Lemberg, by Cyllene, 3 yrs., 9 st. 2 lb. . . . . . Lord Rosebery's Neil Gow, by Marco,

3 yrs., 9 st. 2 lb. . . . . D. Maher o Captain F. Forester's Placidus, 3 yrs., 8 st. $6 \mathrm{lb}$.

B. Dillon o Mr. W. Astor's Mirador, 4 yrs., 9 st. I I lb. Mr. W. Astor's Salamis, 3 yrs., 8 st. 6 lb. Mr. G. A. Prentice's Montreal, 3 yrs., 8 st. $6 \mathrm{lb}$ W. Saxby 3 H. Jones 0 C. Trigg $\mathrm{o}$

Betting. - 5 to 4 against Lemberg, 6 to 4 Neil Gow, 7 to I Placidus, 33 to I Mirador. A dead heat ; third beaten five lengths. Stakes divided.

Lemberg had of course been liberally entered. He was in the three chief races for which he was eligible at Liverpool, also the Duchess of York Plate and the Lennox Plate at Hurst Park; but his owner had decided to have him trained for the Leger, and he was delivered at Doncaster fit and well, the last of the classics being regarded as so good a thing for him that odds of 5 to 4 on were laid. The only other one supposed to have any real chance was Swynford, though fillies have done such remarkable things at this period of the season that Mr. Waldorf Astor's Winkipop found backers at ro to I, and Sir William Bass's Rosedrop, winner of the Oaks-which it was maintained, however, that Winkipop ought to have I 38 


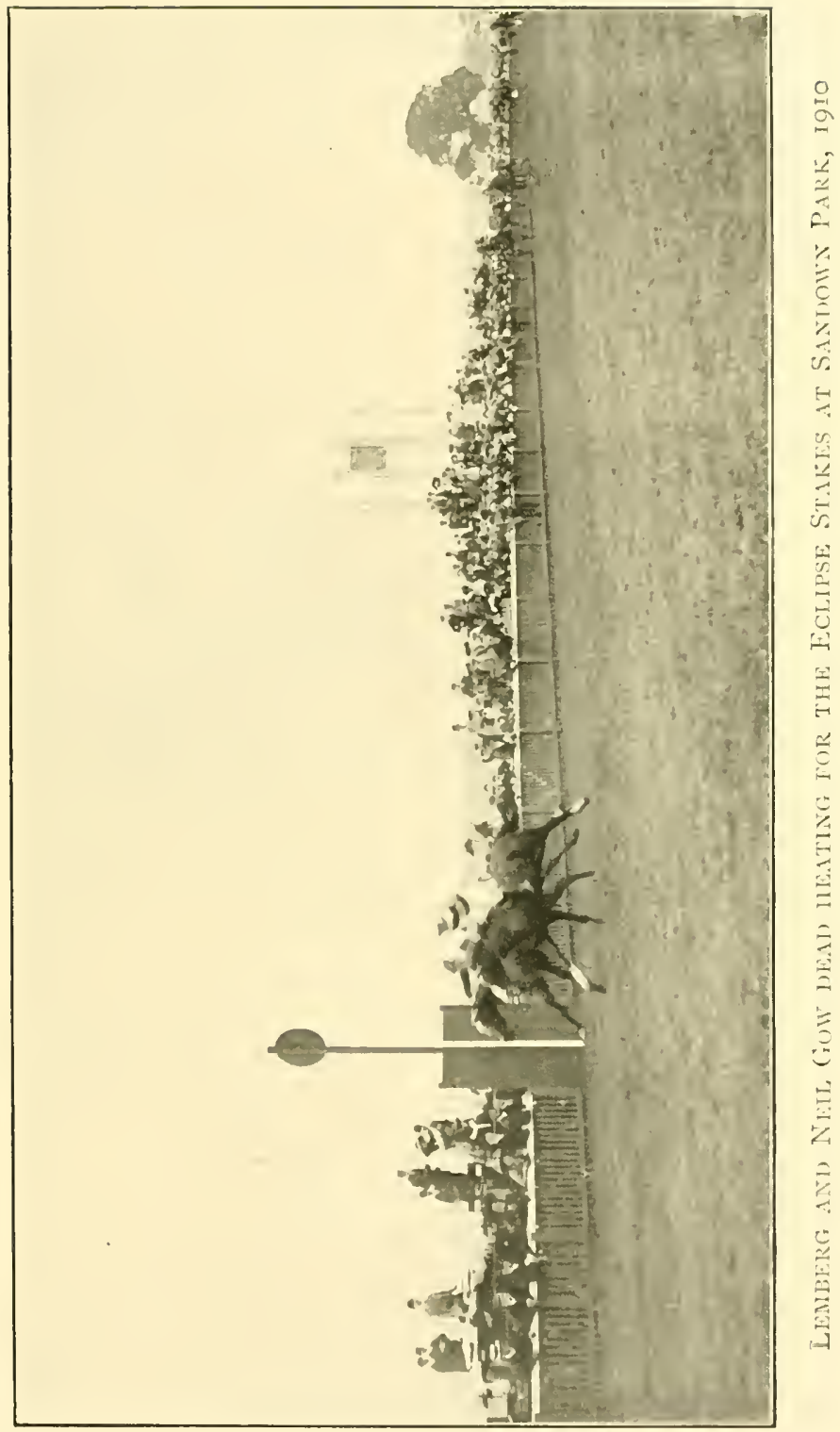





\section{AND HER OFFSPRING}

won-at Ioo to 7. Sivynford was known to have come on extraordinarily since, as recorded, Lemberg had so readily disposed of him in the St. James's Palace Stakes. That race had, indeed, brought him on sufficiently to enable him to win the Hardwicke Stakes next day, and Mr. George Lambton had tried him so highly that it was believed he could not be beaten for the Liverpool Cup, which he won in a canter by five lengths, carrying 7 st. 4 lb. In the September of I9ro, however, it was not supposed that Swynford was the equal of the Derby winner, and the Doncaster result was therefore somewhat surprising.

Swynford, as just remarked, had made phenomenal improvement. His admirers, and not without cause, were disposed to set him down as a great horse; but the explanation of this Leger seems to be that Maher rode a very bad race on Lemberg. It is conceivable that Swynford might just have beaten him, but no one with an appreciation of form will believe that Lemberg ought to have been beaten by over a length and a half, and particularly that Mr. J. A. de Rothschild's Bronzino should have beaten the Derby winner by the margin given, or indeed by any sort of margin. In spite of the Grand Prix I should have been inclined to handicap Lemberg as fully a stone 


\section{GALICIA : HER FORBEARS}

better than Bronzino. As a three-year-old this latter colt was out nine times and won a couple of races worth together $£$ I 859 . As a two-year-old he was out nine times without getting nearer than third. As a four-year-old he won nothing. As a five-year-old he made one appearance. It may be said that he was trying to do something, but he did not do it. In all he ran in two-andtwenty races and won the odd two; and this was the colt who beat Lemberg a length and a half ! Of course it was wrong, recognition of which, however, afforded little recompense to the layers of odds.

Doncaster, I 9 Io.

St. Leger Stakes of $£ 6500$ (including $£_{500}$ for nominator of winner), with $£_{400}$ for second and $£_{200}$ for third, by subscription of $£_{50}$ each, h. ft., or $£ 5$ if declared, with $£ 835$ added; for three-yearolds, entire colts and fillies; colts 9 st., fillies 8 st. I I lb. Old St. Leger Course, about I m. 6 fur. I 32 yds. (338 entrants, viz. I I at $£ 50,204$ at $£ 25$, and 125 at $\oint_{5}-\oint_{6450}$.)

Lord Derby's br. c. Swynford, by John o'Gaunt, 9 st. . . . F. Wootton I Mr. J. A. de Rothschild's ch. c. Bronzino, 9 st. . . . . F. Fox 2 Mr. Fairie's b. c. Lemberg, 9 st. . D. Maher 3 Mr. P. Ralli's b. c. Wolfe Land, 9 st. Wm. Griggs o Mr. H. Lytham's b. c. Marajax, 9 st. S. Wootton o Prince Ladislas Lubomirski's br. c. Ksiaze Pan, 9 st. . . . J. Winkfield o 


\section{AND HER OFFSPRING}

Sir W. Bass's ch. f. Rosedrop, 8 st.
I I lb.
B. Dillon
O

Mr. W. Astor's b. f. Winkipop, 8 st.

Mr. J. Musker's b. c. William Cope, 9 st.

Mr. G. Aston's ch. c. King of the Wavelets, 9 st.

H. Jones

C. Trigg o

Mr. J. A. de Rothschild's br. c. Nankeen, 9 st. . . . . J. M'Dermott o

Betting. - 5 to 4 on Lemberg, 9 to 2 against Swynford, 10 to I Winkipop, 100 to 7 Rosedrop, 20 to I Bronzino, 33 to I Wolfe Land, 40 to I Marajax and Ksiaze Pan, Ioo to I William Cope, 200 to I Nankeen and King of the Wavelets. Won by a head; one and a half lengths second and third.

After the Doncaster week Lemberg had four engagements and fulfilled them all, a fact which gives evidence of his soundness. His first race was for the Jockey Club Stakes, one of the only two nominal $£$ ro,ooo races which now remain. The little spurt of extravagant prizes which marked the later eighties of the last century did not prove remunerative to the executives which organised them. It is difficult to suppose that Lemberg would not readily have won the Jockey Club Stakes from the best of those who were left in. As it happened he had comparatively nothing to beat. Ulster King had won the valuable Princess of Wales's Stakes at Newmarket, and I 4 I 


\section{GALICIA : HER FORBEARS}

there were supposed to be some possibilities about him as he came from what is known as a "dangerous stable." Manton, though it scarcely comes under that designation, for a dangerous stable is understood to imply the production of winners whose victories are not expected, has always been very dangerous indeed; it was so in the days of Alec Taylor, senior, and has remained so under the control of his son.

Newmarket, I 9 IO.

Jockey Club Stakes of $£$ IO,000, of which second received $£_{1} 500$ and third $£_{750}$, nominator of winner $£ 400$, and nominator of second $£ 200$; by subscription of $£ 5$ each for three-year-olds if declared by October 13,1908 , or $f_{1} 10$ for four-year-olds and upwards if declared by March 3I, I908; if left in after those dates a further $£ 2 \mathrm{I}$; if left in after March 30,1909 , a further $£ 32$; and if left in after January 4 , 1910, a further $£ 52$ each; with $£ 842$ added ; last one mile and three-quarters of Cesarewitch Course. (2I 2 entrants, viz. 8 at $\oint_{1}$ I 5,27

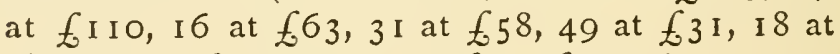
$£ 26,32$ at $£ 10$, and $3 \mathrm{I}$ at $£ 5-£ 7440$.)

Mr. Fairie's Lemberg, by Cyllene, 3 yrs.,
9 st. 6 lb. .
D. Maher I

Mr. J. S. Morrison's Dibs, 5 yrs., 9 st. I I lb.

F. Wootton 2

Mr. E. A. Wigan's Ulster King, 3 yrs., 8 st. I $3 \mathrm{lb}$.

W. Saxby 3

Mr. Reid Walker's Duke Michael, 4 yrs., 8 st. I $2 \mathrm{lb}$.

W. Higgs 0 


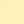




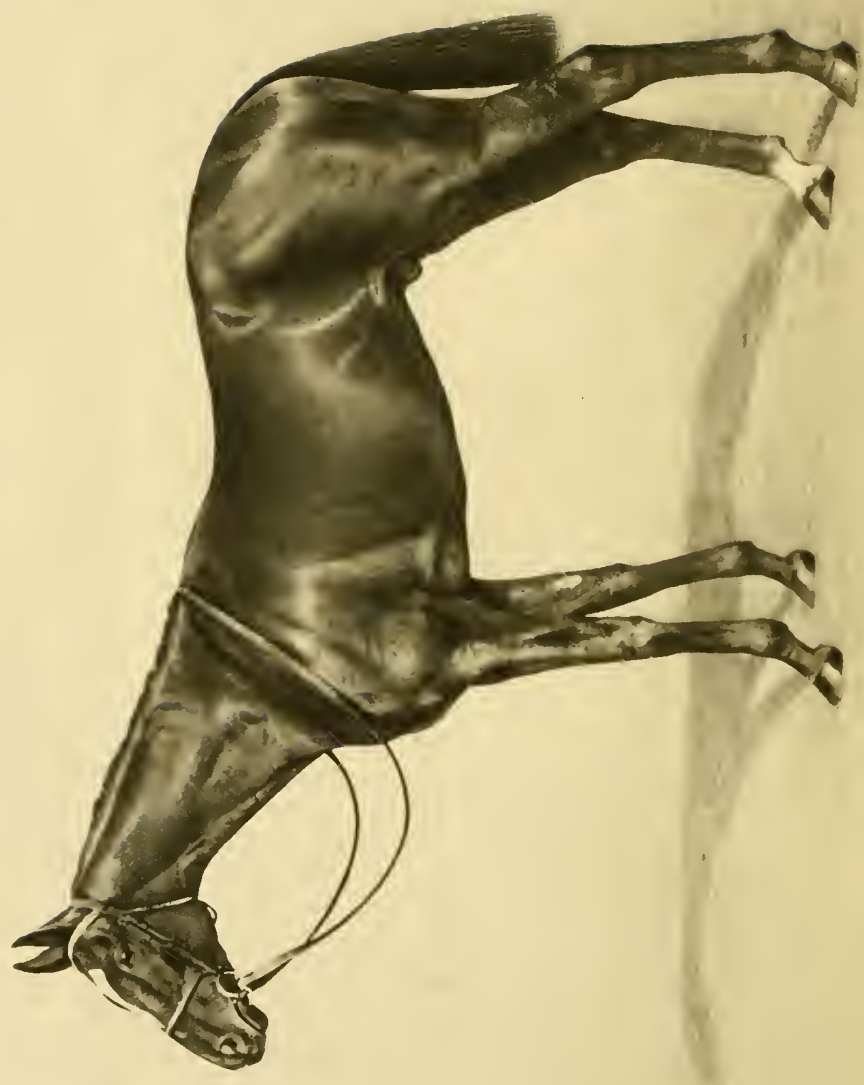

8

2

1)

i

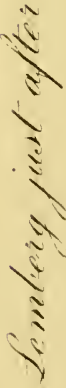




\section{AND HER OFFSPRING}

Mr. J. Daly's St. Michan, 5 yrs., 9 st. 8 lb. M. Colbert O Lord Durham's Charlemont, 3 yrs., 8 st. I o lb. F. Fox

o

Duke of Westminster's Dumella, 3 yrs.,

8 st. 7 lb. (car. 8 st. 8 lb.) . . H. Jones o Mr. L. Brassey's Bernard, 3 yrs., 8 st.
I I lb.
R. Keeble o

Chev. E. Ginistrelli's Star of Naples, 3 yrs., 7 st. $4 \mathrm{lb}$.

J. Brown o

Betting. -3 to I on Lemberg, 100 to 9 against Ulster King, 100 to 6 Dibs, 20 to I Charlemont, 25 to I Duke Michael, 50 to I St. Michan and Dumella. Won by three lengths; head second and third.

Dibs, a self-willed creature who used to give a great deal of trouble at the start, was really no more than a handicap horse, and in fact Lemberg won without an effort. He came to Newmarket for the Champion Stakes at the Second October Meeting to encounter Dean Swift, an old gelding who was not to be despised though doubtless in a different class from the colt he was meeting here. Dean Swift, it need scarcely be said, for it is to be assumed that readers of these pages have some acquaintance with Turf affairs, had won the City and Suburban in 1906, again in 1908, and on other occasions had come near to success in the same Handicap. He seemed to improve with age, contrary to the usual order of things. In his race prior to the one under discussion he had been beaten two heads for the Chesterfield Cup 


\section{GALICIA : HER FORBEARS}

at Goodwood, giving the winner, Captain J. G. R. Homfray's Land League, i $3 \mathrm{lb}$. No one had any idea that he would beat Lemberg, however.

Champion Stakes, $f_{900}$ A.F., one and a quarter miles. Mr. Fairie's Lemberg, 3 yrs., 8st. 8 lb.

(I lb. extra) . . . D. Maher I Mr. J. B. Joel's Dean Swift, aged, 9 st. Walter Griggs 2 Betting.-I IOO to I 2 on Lemberg. Won by six lengths. Time, 2 mins. $8 \frac{2}{5}$ secs.

As noted, Dean Swift had been out against Bayardo. A couple of days later Lemberg reappeared for the Lowther Stakes, which looked quite as great a certainty, and I have no idea why bookmakers were willing to take a shorter price.

Lowther Stakes, £490. Last mile and three-quarters of the Cesarewitch Course.

Mr. Fairie's Lemberg, 3 yrs., 9 st. 7 lb. .

D. Maher I Sir Ernest Cassel's Nimrod, 5 yrs., 8 st.
Io $\mathrm{lb}$.
E. Shaw
2

Col. W. Hall Walker's Royal Realm,

5 yrs., 9 st. $10 \mathrm{lb} . \quad$. . W. Griggs 3

Mr. J. S. Morison's Dibs, 5 yrs., 9 st.

$4 \mathrm{lb}$.

F. Wootton 4

Betting.-4 to I on Lemberg, 8 to I against Dibs, I 00 to I 2 Royal Realm, 33 to I Nimrod. Won by two lengths; short head. Time, 3 mins. $10 \frac{2}{5}$ secs.

Dibs had run for the Cesarewitch the previous afternoon, which was not likely to have done him 


\section{AND HER OFFSPRING}

any good, but the ease with which Lemberg had beaten him in the Jockey Club Stakes when the five-year-old was giving $5 \mathrm{lb}$. showed that it practically made no difference whether he was giving or receiving what was in the circumstances a trifle. Royal Realm was a horse of some character, though not calculated to extend Lemberg. 'The colt's remaining engagement was at Sandown and gave him no sort of trouble.

Sandown Foal Stakes for Three-Year-Olds. £I 724.

Eclipse Stakes Course, one mile and a quarter.

Mr. Fairie's Lemberg, 9 st. Io lb. . D. Maher I Mr. Walter Raphael's Louvigny, 8 st.

Io lb.

Lord Carnarvon's Munita, 8 st. 7 lb. . W. Higgs 3 Lord Durham's Brancepeth, 7 st. I I lb. F. Fox (left) 0

Betting. - 100 to 7 on Lemberg, 20 to I against Louvigny, 33 to I others. Won by two lengths; five lengths second and third. Time, 2 mins. $42 \frac{4}{5}$ secs.

Louvigny was a half-brother to Louviers, who had run King Edward's Minoru to a head for the Derby, but he never did much. It is improbable that the fact of Brancepeth having been left at the post made any difference to the result. Lemberg had thus won seven of the nine races for which he started as a three-year-old, counting the Eclipse Stakes as a victory, and the very short head in the Two Thousand Guineas had cost him an eighth. 


\section{GALICIA : HER FORBEARS}

As a four-year-old he did not entirely sustain his reputation throughout the season. That must be admitted if his career is critically regarded, but he assuredly continued to show himself a colt of very high character. He was not brought out until the Coronation Cup on the day after the Derby, and began his four-year-old season triumphantly, having shown himself to be well in a mile and a half gallop at Manton on the 23rd May. Here are details :

Lemberg, 4 yrs., 9 st. 9 lb. . . . Dillon I Phryxus, 3 yrs., 8 st. 4 lb. . . . . Trigg 2 Royal Eagle, 3 yrs., 8 st. 7 lb. . . . Clark 3 Cyllius, 3 yrs., 7 st. I I lb. . . . . Avery 4 Declare, 5 yrs., 9 st. 2 lb. . . . . Ault 5

Won by half a length; five lengths between second and third. Lemberg won easily.

Epsom, I 9 I I.

Coronation Cup, a Gold Cup value $£ 200$, and $£$ iooo in specie, added to a Sweepstakes of $£ 20$ each, or $£ 5$ if declared, with $£ 100$ added for second and $f_{50}$ for third ; for three-year-olds and upwards ; Derby Course, about one mile and a half. (25 entrants, viz. 23 at $£ 20$ and 2 at $£ 5-£ 1650$.)

Mr. Fairie's Lemberg, by Cyllene, 4

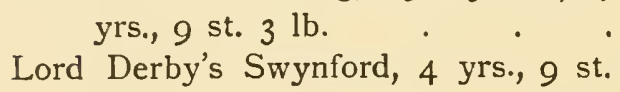

$3 \mathrm{lb}$.

B. Dillon I

F. Wootton 2 146 


\section{AND HER OFFSPRING}

Sir George Murray's Bachelor's Double,

5 yrs., 9 st. 6 lb. . . . G. Stern 3

Mr. C. S. Donnelly's Buckwheat, 5 yrs.,

9 st. 6 lb. . . . . C. Trigg o

Mr. A. P. Cunliffe's Charles O'Malley,

4 yrs., 9 st. 3 lb. . . . S. Donoghue o

Mr. J. A. de Rothschild's Bronzino, 4

yrs., 9 st. $3 \mathrm{lb}$. . . . F. Fox

Lord Villier's Greenback, 4 yrs., 9 st.

3 lb. . . . . F. Templeman o

Mr. P. Nelke's Yellow Slave, 4 yrs.,

9 st. . . . . . D. Maher

Betting. -9 to 4 against Bachelor's Double and Lemberg, 5 to I Swynford, 6 to I Bronzino, Ioo to 7 Greenback, 100 to 6 Charles O'Malley. Won by threequarters of a length; head second and third.

The great thing here is that he beat Swynford, thus avenging himself for his defeat in the Leger the previous year; and, moreover, Dillon, who wore Mr. Fairie's colours, was scarcely the equal of F. Wootton as a jockey, which is all to the credit of the colt Dillon rode. At the same time Mr. George Lambton declares that Swynford was backward at this period, though nevertheless rather more than a month before he had won the Chippenham Plate at the Newmarket First Spring Meeting, when, however, it is true that he had nothing to beat. The form was nevertheless accepted by racegoers at large, and when Lemberg next appeared, for the Princess of Wales's 


\section{GALICIA : HER FORBEARS}

Stakes at the Newmarket First July Meeting, odds were freely laid on him.

Newmarket, I 9 I I.

Princess of Wales's Stakes of $£ 30$ each starter, $h$. $\mathrm{ft}$. or $£ 3$ if declared, with $£ 2000$ added, of which owner of second received $£ 300$ and owner of third $£ 200$, nominator of winner $£ 300$ and nominator of second $£ 200$; for three- and four-year-olds. Suffolk Stakes Course, one mile and a half. (I 72 entrants, $£_{3} \mathrm{ft}$. declared for $55-£ 3265$.)

Lord Derby's Swynford, by John O'Gaunt, 4 yrs., IO st. I lb. . F. Wootton I Mr. Fairie's Lemberg, 4 yrs., Io st. $6 \mathrm{lb}$.

B. Dillon

Lord Derby's King William, 3 yrs., 9 st.
Mr.Leopold de Rothschild's St. Andrea, 3 yrs., 8 st. I lb.

D. Maher

Mr. J. A. de Rothschild's Bryony, 3 yrs., 7 st. 7 lb.

C. Trigg

$\circ$

Betting.-6 to 4 on Lemberg, 3 to I against Swynford, 9 to 2 King William, 33 to I Bryony. Won by one and a half lengths ; length second and third.

It will be observed that Lemberg was giving Lord Derby's colt 5 lb., a serious consideration over a severe mile and a half. Swynford had incidentally cantered away with the Hardwicke Stakes at Ascot, and was, there is no denying, an altogether exceptionally good animal. He was indeed the one horse then in training by I 48 


\section{AND HER OFFSPRING}

whom it was no discredit to be beaten; and that the form was sufficiently correct was demonstrated a fortnight afterwards in the Eclipse Stakes at Sandown, where the two met again. I cannot find that there was any excuse for Lemberg in this race, and it will be seen that he merely did what was expected, the betting being accepted as an indication. Swynford had been making the greater improvement; it must have been so, as the Eclipse Stakes course was certainly quite as well suited for Mr. Fairie's colt as for the long striding son of John o' Gaunt and Canterbury Pilgrim.

Sandown Park, I9I I.

Twenty-fourth Renewal of the Eclipse Stakes of $£_{10,000}$ of which owner of second received $£_{900}$, of third $£_{150}$, nominator of winner $£_{500}$, and nominator of second $£_{100}$; by subscription of $£_{5}$ each for three-year-olds if $\mathrm{ft}$. declared by October 12 , I 909, or £IO for four-year-olds if declared by March 30, I909; if left in after those dates a further $£_{2}$ I each; if left in after March 29, I 9 I O, a further $£_{34}$ for three-year-olds, or $£_{32}$ for fouryear-olds; and if left in after January 3 , I 9 I I, a further $£_{55}$ for three-year-olds, or $£_{52}$ for fouryear-olds; with $£_{349}$ added. Eclipse Stakes Course, one mile and a quarter. (205 entrants, viz. 42 at $£_{11} 5$, I 8 at $£_{63}, 22$ at $£ 60,44$ at $£_{31}, 23$ at $£_{26}$, 25 at $£_{10}$, and 3 I at $£_{5}-£ 8735$.)

Lord Derby's Swynford, by John o' Gaunt, 4 yrs., Io st. F. Wootton I 


\section{GALICIA : HER FORBEARS}

Mr. Fairie's Lemberg, 4 yrs., Io st. B. Dillon

2

Mr. Leopold de Rothschild's Pietri,

3 yrs., 8 st. I 3 lb. .

Mr. H. P. Whitney's Whisk Broom,

4 yrs., 9 st. $8 \mathrm{lb}$. . . . J. H. Martin O

Mr. R. W. Burrows' Placidus, 4 yrs.,

9 st. 4 lb. . . .

Mr. G. Aston's King of the Wavelets,

4 yrs., 9 st. 4 lb. . . .

Mr. P. Nelke's Yellow Slave, 4 yrs.,

J. Clark

○

C. Trigg o

9 st. $8 \mathrm{lb}$.

F. Templeman 0

Betting. - I I to Io on Swynford, 9 to 4 against Lemberg, 9 to I Whisk Broom, I oo to 6 Pietri, 50 to I Yellow Slave and Placidus, 500 to I King of the Wavelets. Won by four lengths; same second and third.

An interesting question came up for examination at Doncaster: whether Lemberg could stay? That his owner was convinced he could do so is shown by the fact of his having been put into the Doncaster Cup, run over a distance of two miles one furlong. There was one horse in the race whose capacity as a stayer had been thoroughly demonstrated-Lord St. Davids' Kilbroney, a son of The Wag and Innismakil. In the matter of class Kilbroney was admittedly in very poor contrast to the son of Cyllene and Galicia. Either a horse can stay or he cannot, however, and if he cannot, class is not of much avail against genuine stayers. Before going to Doncaster, Kilbroney had won the Goodwood Cup from 


\section{AND HER OFFSPRING}

a staying filly, Martingale II, who afterwards ran second to Willonyx for the Cesarewitch. Kilbroney had won the Great Metropolitan at Epsom that Spring, the Summer Handicap at the Newmarket Second July, giving I6 lb. to Clarenceux, a colt of his own age who started there a strong favourite at 2 to $\mathrm{I}$. Prior to that Kilbroney had failed by a neck to beat a good horse called Pillo in the Northumberland Plate, giving the six-year-old winner $6 \mathrm{lb}$. He was therefore by no means to be despised.

Doncaster, I 9 I I.

Doncaster Cup, value $£ 200$, with $£$ Iroo in specie added, of which second received $£ 200$ and third

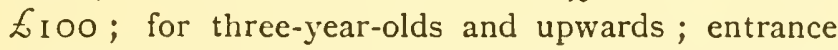
$£_{\mathrm{I} O} £_{5} \mathrm{ft}$. Two miles one furlong over Old Course. (34 entrants-£990.)

Mr. Fairie's Lemberg, by Cyllene,
4 yrs., IO st.
F. Wootton I

Lord St. Davids' Kilbroney, 4 yrs.,

Io st. . . . . .

Sir John Thursby's Adalis, 4 yrs., 8 st.

$5 \mathrm{lb}$.

Mr. P. Ralli's Wolfe Land, 4 yrs.,

9 st. 4 lb. . . . .

Walt. Griggs 2

Lord Rosebery's Black Potts, 3 yrs.,

8 st. I lb. . . .

C. Trigg

B. Dillon o

Mr. T. Frost's ch. f. by Count Schom-

berg-Persil, 3 yrs., 7 st. 8 lb. . J. Howard o

Betting.-9 to 4 on Lemberg, 9 to 2 against Kilbroney, Io to I Wolfe Land, Ioo to 7 Adalis and Black Potts, 


\section{GALICIA: HER FORBEARS}

50 to I Persil f. Won by a neck; four lengths second and third.

The neck could have been extended, and the result must have been satisfactory to Lemberg's owner, who I am inclined to think had at any rate not imagined that staying was Lemberg's strong point. It is to be noticed that though he was entered for the Gold Cup he was not sent to Ascot.

In the Jockey Club Stakes Lemberg was stopped by his weight. He encountered a really good animal in Lord Derby's Stedfast, one of the best horses of the period. Between Stedfast and Mr. W. Pilkington's Prince Palatine, winner of two Ascot Cups, it was agreed that for a long period there was nothing to choose-and Prince Palatine is standing at a fee of 400 guineas. An accident on the road, a fall which severely injured his knees notwithstanding that he had caps on at the time, left ill effects on Stedfast. It must have been so, for in the Jockey Club Stakes of 1912 Prince Palatine gave him I 3 lb. and beat him half a length, which could not have happened if Stedfast had been himself. He was at his best, however, when he met Lemberg in this race, and Mr. Fairie's colt, by reason of penalties which Stedfast had escaped, was giving $16 \mathrm{lb}$. more than weight-for-age. 


\section{AND HER OFFSPRING}

Stedfast benefited by a $9 \mathrm{lb}$. breeding allowance, and Lemberg was giving 2 st. instead of the I 2 lb. a four-year-old should give a three-yearold according to the conditions of the race.

Newmarket, I9II.

Jockey Club Stakes of $£_{1} 0,000$; second received $£_{1} 500$ (being $£_{1232,}$ I $3 \mathrm{~s} .4 \mathrm{~d}$. out of the stakes and $£ 267,6$ s. 8d. from surplus subscriptions), and third $£ 750$ (being $£ 616,6 \mathrm{~s}$. 8d. out of the stakes and $£$ I 33 , I 3s. 4d. from surplus subscriptions); nominator of winner received $£_{400}$, and nominator of second $£ 200$ out of the stakes; by subscription of $£_{5}$ each for three-year-olds if declared by October i 2 , I 909 , or $£$ IO for four-year-olds and upwards if declared by March 30, I 909 ; if left in after those dates a further $E_{2 I}$; if left in after March 29, I9IO, a further $£_{32}$; and if left in after January 3 , I 9 II, a further $£_{52}$ each; last one mile and three-quarters of the Cesarewitch Course. (2 I o entrants, viz. I 7 at

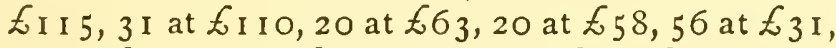
20 at $£_{26}, 26$ at $£_{10}$, and 20 at $£_{5}-£_{784} \mathrm{I}$.)

Lord Derby's Stedfast, by Chaucer, 3 yrs., 8 st. 4 lb. . . . . F. Wootton I

Mr. Fairie's Lemberg, 4 yrs., Io st. 4 lb. F. O'Neill 2 Lord Derby's Hair Trigger II, 3 yrs., 7 st. I 2 lb. . . . . F. Rickaby 3

Mr. J. B. Joel's Lycaon, 3 yrs., 8 st. Io lb. . . . . . G. Stern o Lord Durham's Cyrano, 3 yrs., 8 st. 7 lb. J. Clark o Betting.-2 to $\mathrm{I}$ on Stedfast, 9 to 2 against Lemberg, 8 to I Lycaon, Io to I Hair Trigger II. Won by four lengths; three lengths second and third. 


\section{GALICIA : HER FORBEARS}

The betting shows that according to general opinion Lemberg was overtaxed. For the rest he walked over for the Champion Stakes at the Second October Meeting, and practically walked over for the Lowther Stakes, having only to meet a three-year-old called Bryony, who had got home once during the season in ten races. This was Lemberg's last appearance, and I may set out the record of his achievements as I have done in the case of his brother.

$$
\text { As a Two-Year-Old. }
$$

The New Stakes, Ascot

The Chesterfield Stakes, Newmarket $£ 2,013$

The Rous Memorial Stakes, Goodwood

The Champagne Stakes

The Rous Memorial Stakes, Newmarket .

I , I 25

The Middle Park Plate.

The Dewhurst Plate

\section{As a Three-Year-Old.}

The Two Thousand Guineas .

The Derby .

The St. James's Palace Stakes

The Eclipse Stakes

The Jockey Club Stakes

The Champion Stakes .

The Lowther Stakes

The Sandown Foal Stakes The St. Leger

.
.
$\cdot$
$\cdot$
.
.
$\cdot$

$£ \ldots$

6,450

2,450

4,385

7,440

900

490

I, 724

$£ 23,839$ 


\section{AND HER OFFSPRING}

As a Four-Year-Old.

The Coronation Cup, Epsom .

The Prince of Wales's Stakes, Newmarket

The Doncaster Cup $£ \mathrm{I}, 650$

The Champion Stakes

The Lowther Stakes

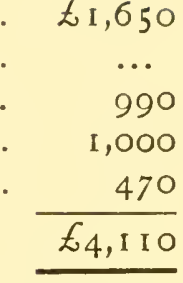

During his three years in training, therefore, Lemberg won in stakes a sum of $f_{37,309}$. In this calculation I am taking the Eclipse Stakes at what it actually yielded to the owner, though in the totals published at the end of the season the whole amount of a stake is usually credited to a dead heater. To the aggregate named there is a considerable amount of place money to be added. As a two-year-old this was only a matter of $65^{\circ}$ for his third in the Champagne Stakes. As a three-year-old Lemberg earned $£, 400$ for his second in the Two Thousand Guineas, $£ 200$ for his third in the St. Leger. The second in the Princess of Wales's Stakes received $£_{500} £_{3} 300$ going to the owner and $£ 200$ to the nominator. In the Eclipse Stakes the owner of the second horse received f.900, the nominator an additional £roo. Half this went to Lemberg. He was also, as recorded, second for the Jockey Club Stakes, which brought 


\section{GALICIA : HER FORBEARS}

in $f_{1700 .}$ Including place money Lemberg's total of winnings therefore amounts to $£ 40,659$. In all he ran 23 races and won 17 . Real good horse as Lemberg was, I think his owner reckons Galicia's elder son as distinctly the better of the pair, though he might pause for a long time before endeavouring to estimate the superiority in pounds. Lemberg's offspring have not run up to the period when I finish this book. 


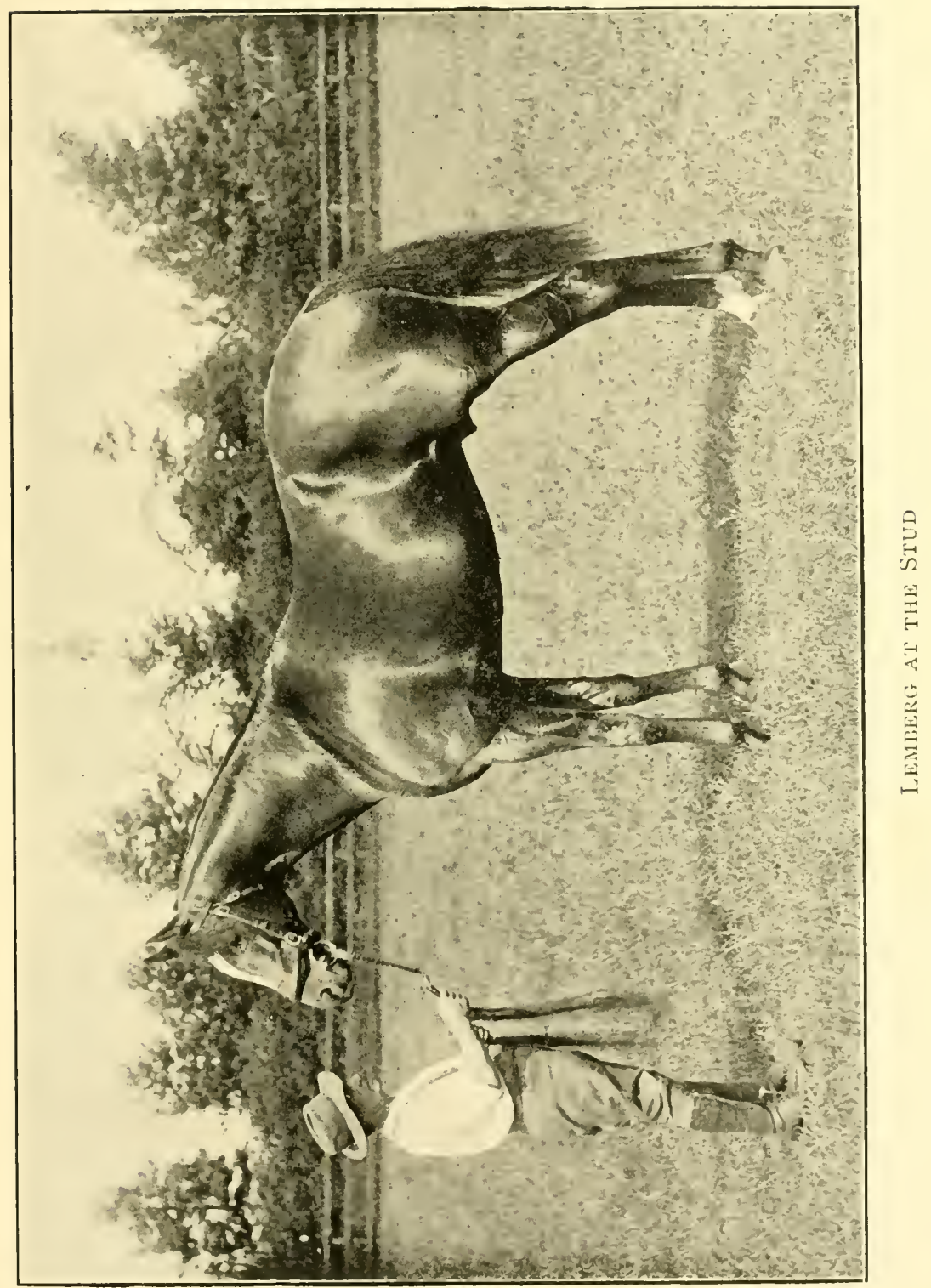





\section{AND HER OFFSPRING}

\section{CHAPTER V}

SILESIA, ZIA, AND RADAMES

IN 1909 the question arose to whom Galicia was to be sent, and Mr. Fairie decided on Major Eustace Loder's Spearmint, who was standing in Ireland at a fee of $25^{\circ}$ guineas. Spearmint was certainly one of the most extraordinary animals in the history of racing. With scarcely an exception winners of the great classic races have been home-bred, that is to say, have victoriously carried the colours of their breeders. Spearmint, however, had been purchased at auction for the moderate selling plater price of 300 guineas. It is always well to avoid superlatives, but it may be doubted whether there was ever a cheaper horse than this son of Carbine and Maid of the Mint. At his first appearance he won the Great Foal Stakes at Lingfield Park, worth a nominal $£ 1000$ and really yielding $£ 8_{35}$. He was beaten for the Champion Breeders' Foal Stakes at Derby, finishing second to Colonel Hall Walker's Black Arrow; and carrying 9 st. he ran well up, fourth, for a Nursery at Newmarket. As a 


\section{GALICIA : HER FORBEARS}

three-year-old Spearmint was only out twice, once in England, when he won the Derby from one of the best fields known for several years, and once in France, where he won the Grand Prix, starting, moreover, at a shade of odds on. This was Spearmint's last appearance. He had run five races and won three of them worth E 1 7,239. The Grand Prix varies largely in value ; in Spearmint's year it was $£$ ro,oo8, after which there was a marked increase, Sardanapale in I9I4 having brought in $\mathcal{E}_{14}, 326$.

The result of Galicia's visit to Major Eustace Loder's horse was a filly foal whom her owner called Silesia. She was pronounced remarkably good-looking by those who have the gift of judging the very youthful thoroughbred, and as a matter of course she was entered much as her distinguished half-brothers had been, except, indeed, that her first engagement was the Acorn Stakes, which, needless to say, is exclusively for fillies. "Races to Come" showed her in the Coventry and Windsor Castle Stakes at Ascot, the July Stakes, the National Breeders' Produce Stakes at Sandown, the Great Lancashire Breeders' Produce Stakes of $£ 2000$ at Liverpool, the Hurst Park Foal Plate of $£_{1500,}$ the Richmond Stakes at Goodwood, as also the Prince of Wales's Stakes at the same meeting, a Breeders' I 58 


\section{AND HER OFFSPRING}

Foal Plate at Kempton Park, a similar race at Manchester, the Buckenham Stakes, the Imperial Produce Plate at Kempton, the Cheveley Park Stakes and the Moulton Stakes, though for some reason she was left out of the Middle Park and Dewhurst Plates. Had she been in these her engagements would have seemed a model list of those which might be judiciously selected for a two-year-old of the highest class.

I have a recollection of asking her owner one day how she was progressing, for at the time Bayardo and Lemberg had made great names for themselves, and there was natural curiosity to know whether their sister was likely to rival their achievements. In this book I am saying as little as possible about the owner himself, for reasons which many of those who see the little volume will understand. Mr. Fairie prefers to remain in the background; but I may remark that he spoke with something approaching to enthusiasm of the promise Silesia was giving, of her resemblance to Bayardo in make and shape so far as a filly can resemble a colt, and furthermore in her action. Disappointment was expressed as the stakes into which she had been put passed by without her production. In fact, she did not run as a two-year-old, and next season was so far a further disappointment that she never 


\section{GALICIA: HER FORBEARS}

won anything, though she took part in eight races. They were all, however, events of an important character. If $\mathrm{Mr}$. Fairie had cared about the mere fact of winning, no doubt she might have run up a little score of successes. He kept her strictly to her engagements, she was sound and well, and she filled rather more than half of them, they having been fifteen in all. I shall not quote them in detail, seeing that her name never occupied the first place, but details of her performances in the classics may be given.

One Thousand Guineas Stakes. $£_{4750}$. Three-yearold fillies, 9 st. each. Rowley Mile.

Mr. Walter Raphael's Tagalie . . L. H. Hewitt I Baron G. Springer's Alope . . B. Carslake 2 Lord Falmouth's Belleisle . . . H. Jones 3 Mr. S. B. Joel's Polkerris . . . S. Wootton 4 Mr. Lionel Robinson's Bill and Coo . F. Winter 5 Colonel W. Hall Walker's Lolette . W. Earl 6 Sir Berkeley Sheffield's Fair Relative . C. Trigg 7 Lord Derby's The Tylt . . . F. Rickaby 0 Lord Durham's Golden Note . . J. Clark o Mr. Eustace Loder's Mountain Mint . Walter Griggs o Mr. P. Nelke's Miss Spearmint . . F. Templeman o Mr. Fairie's Silesia . . . . J. H. Martin o Lord Rosbery's Charmian . . D. Maher O

Betting.-7 to 4 against Belleisle, 2 to I Polkerris, 9 to 2 Charmian, 20 to I others. Won by a length and a half; three-quarters of a length second and third. I min. $39 \frac{3}{5}$ secs. 


\section{AND HER OFFSPRING}

Silesia's position among the " 20 to I others" shows that little was expected, and she started at 20 to I, moreover, for the Oaks, a record of which may also be furnished.

Oaks Stakes. Three-year-old fillies. $£_{4950 .}$

9 st. each. About a mile and a half.

Mr. J. Prat's Mirska . . . J. Childs I

Mr. Leopold de Rothschild's Equitable F. O'Neill 2

Mr. Lionel Robinson's Bill and Coo . F. Wootton 3

Lord Derby's The Tylt . . . F. Rickaby 4

Mr. Fairie's Silesia . . . . J. Clark 5

Lord Falmouth's Merry Maiden. . C. Foy 6

Mr. Walter Raphael's Tagalie . . G. Stern 7

Duke of Devonshire's Preferment . W. Higgs 8

Mr. L. Neumann's Sourabaya . . Walter Griggs 9

Lord Falmouth's Belleisle. . . H. Jones o

Mr. J. Musker's Jenny Melton . . F. Hunter o

Sir Berkeley Sheffield's Green Cloth . C. Trigg o

Mr. Peter Gilpin's Lovely Night . W. Saxby o

Colonel Hall Walker's Lolette . . W. Earl (fell) o

Betting.-2 to I on Tagalie, 7 to I against Belleisle, Io to I Bill and Coo, roo to 7 Preferment, 20 to I Silesia, 25 to I each Green Cloth and Merry Maiden, 33 to I others. Won by three lengths; three-quarters of a length second and third. 2 mins. 43 secs.

Mr. Walter Raphael's grey filly, an odds-on favourite it will be perceived, did little. She had won the Derby two days previously and possibly may have been feeling the effects, though that this was not suspected prior to the race is abunI6I 


\section{GALICIA : HER FORBEARS}

dantly demonstrated by the market. Silesia had a special quotation of 4 to $I$ for a place instead of the ordinary fourth of the odds, 5 to $\mathrm{I}$, evidence that she was expected to improve upon her One Thousand running, as it will be seen she did, beating Belleisle, for instance, not to mention Tagalie; but Mirska won with a great deal to spare.

Silesia was sent to Ascot for the Coronation Stakes, which was supposed to be a good thing for Polkerris. Odds of I I to 8 were laid on this filly, Mr. C. Carroll's Melody, a daughter of Meddler and Ballantrae, making her first appearance of the season and sharing second favouritism with Silesia at 7 to $I$, in just slightly stronger demand than Mr. August Belmont's Qu'elle est Belle, a daughter of Spearmint. Silesia was fourth, Polkerris winning by a length from Melody, the latter giving her $4 \mathrm{lb}$. It should have been $7 \mathrm{lb}$., but F. Wootton, who rode, had to put up $3 \mathrm{lb}$. extra, being unable to ride less than 8 st. $6 \mathrm{lb}$. Silesia, with her maiden allowance, carried 8 st. $3 \mathrm{lb}$.

Mr. Fairie sent her to the post for the Eclipse Stakes, remote in the extreme as her prospects obviously were. It was supposed that Stedfast could hardly be beaten, odds of I 3 to 8 being laid on him, Tagalie second in demand at 9 to I 62 


\section{AND HER OFFSPRING}

2, for her Oaks failure was excused, Prince Palatine 5 to I, Lycaon Io to I, Silesia 33 to I, La Bohème II Ioo to I, King William I 50 to I, John Amendall 200 to I. I think that Stedfast ought to have won; but O'Neill on Prince Palatine gave Maher no room, squeezed him on the rails in fact, and beat him by a short head. Lycaon was third, six lengths away, John Amendall fourth, King William fifth, and Silesia next, in front of La Bohème II and Tagalie. At Liverpool it was thought that Silesia had some chance for the Knowsley Dinner Stakes. There were only three runners-Maiden Erlegh, a 9 to 4 on favourite, carried 9 st. 6 lb., Silesia only 7 st. I I lb., and she was backed at I I to 4, being beaten a length and a half, with John Amendall bringing up the rear. Hurst Park was the scene of her next attempt, the Hurst Park Lennox Plate for three-year-olds the prize. Mr. Neumann's Oiseau Bleu, who at the time of writing is performing with indifferent success over hurdles, shared favouritism with Honastir at 5 to 2 , Silesia 7 to I, and the race was taken by the latter's stable companion Equanimity. This daughter of Bachelor's Button carried 7 st. I 2 lb., and won by a head from Honastir, 8 st. I lb. ; Silesia, 8 st. 4 lb., third, beaten a length. A length and a head may perhaps be reckoned at something like $6 \mathrm{lb}$., so that 163 


\section{GALICIA: HER FORBEARS}

- here Silesia comes out much about the same animal as the winner.

It will be seen that she was seldom afforded anything like a real chance, and she certainly did not find one for the Jockey Club Stakes running against Stedfast and Prince Palatine. These two had shown themselves practically inseparable, and as here Stedfast was receiving $\mathrm{I} 3 \mathrm{lb}$. it was supposed that he could not be beaten. Apparently he had not entirely recovered from the effects of his bad fall. Of this I have already written in the previous chapter. Those who had laid 9 to 4 on him, basing their calculations on his previous form with Prince Palatine, proved mistaken, the latter starting at 5 to $\mathrm{I}$ and winning by three parts of a length. Mr. Reid Walker's Adamite was third, five lengths away, Silesia fourth. Her last appearance of the season was in the Newmarket Oaks against two others ; Lord Lonsdale's Eufrosina, 5 to 4 on, gave Silesia, 7 to 4 against, ro $1 b$. and beat her a length. It had been reasonable to expect better things from the good-looking

- half-sister to the two famous sons of the dam. She left the. Turf a maiden, however, and it remains to be seen whether she will follow the example of so many other mares who have won nothing when in training but have earned reputation in the paddocks. 


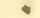

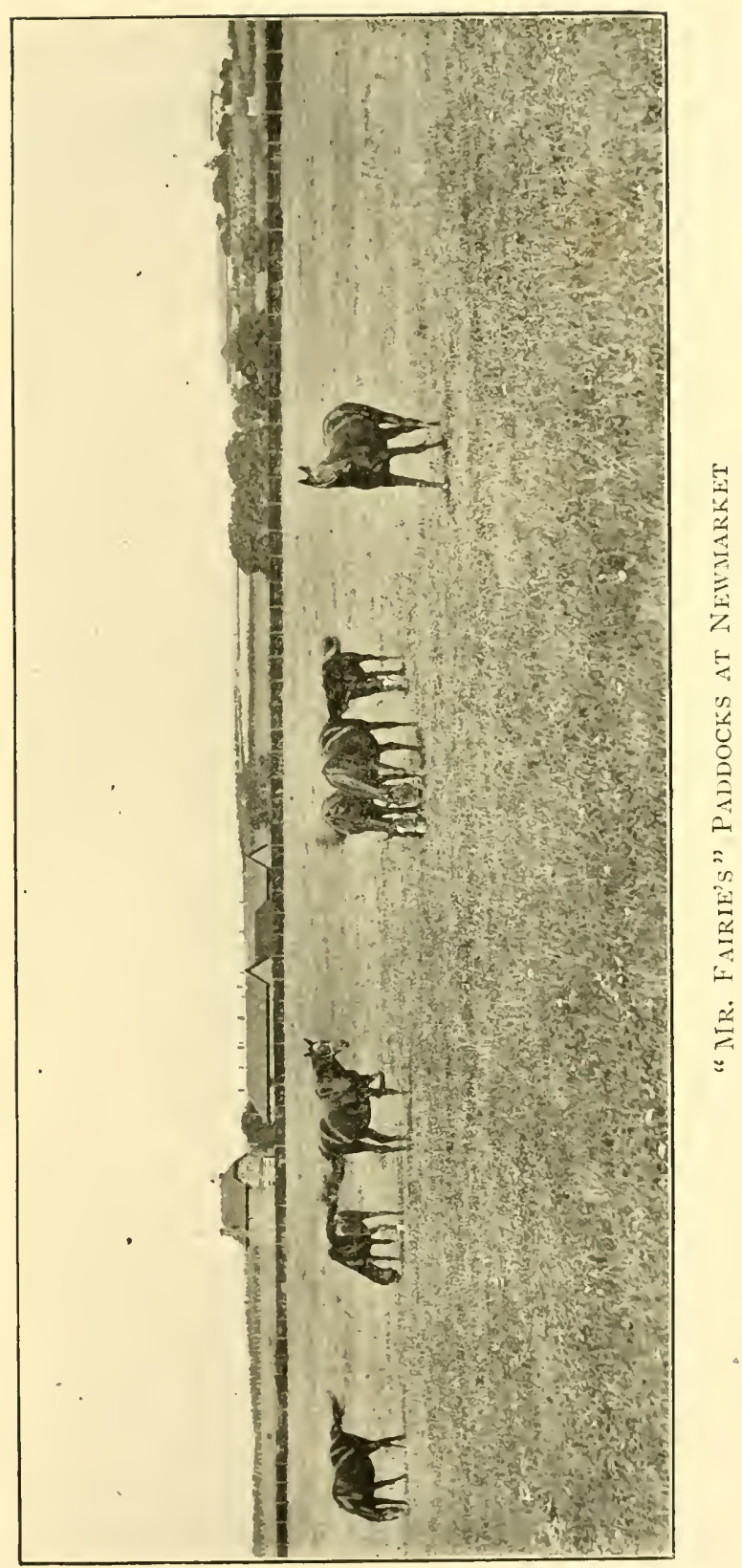





\section{AND HER OFFSPRING}

In 1910 Galicia was sent to Missel Thrush, his winning offspring having included a really good colt called Llangwm, whose three-year-old career had certainly been remarkable. After one failure in the Spring, in the Great Surrey Handicap, a five-furlong sprint down the Epsom hill, Llangwm had been out nine times and had won all his races with the exception of one, that one being the Derby, for which he had been third, beaten two lengths and a neck by Signorinetta and Primer. I have always entertained the strong impression that Llangwm ought to have won the great race, and probably would have done so if Maher, who rode, had been better acquainted with him, for on this occasion at least, or so it seemed to me, the jockey did not distinguish himself favourably. Later in the year, it is to be observed, Llangwm gave Primer $2 \mathrm{llb}$. and beat him a neck, which certainly seems to show that the Epsom running was ludicrously wrong! At any rate, Llangwm's sire was chosen, and what might have been the result must remain a matter of speculation as the mare was barren, a lapse for which she made up next year by producing twins to Radium, a chestnut filly who was born dead and a bay filly called Zia. Of this young one no great opinion was formed, as may be judged from the list of her entries. As a two-year-old she was 165 


\section{GALICIA : HER FORBEARS}

only put into seven races, beginning with the Kineton Stakes at Warwick, 5 sovs. each for starters with 100 added, following on with the Osmaston Plate at Derby, a $£ 200$ race, and the Mostyn Two-Year-Old Plate at Chester, a little stake of the same value. She was also in the Eglinton Stakes of $£$ I5o at York and the Stud Produce Stakes at the Newmarket First July; her other two entries were for Rous Plate at Doncaster, and, her owner taking a chance, somewhat in the nature of a leap in the dark, also nominated her for the valuable Buckenham Stakes of $£ 300$ each, half forfeit, at the Newmarket First October. That year there were only seven subscribers, and there is always, of course, a great possibility that nothing of any importance may be left in.

The list of entries formed a striking contrast to the lists which had been made for Galicia's other offspring, and the event proved that Zia's owner had acted judiciously. The filly was not sent to Manton. She was committed to the charge of Mr. Francis Lambton, who as Captain Lambton met a gallant death on the battlefield in France. Mr. Fairie's horses, with the exception of two or three, remained at Manton; but Mr. Francis Lambton was getting a stable together at Newmarket, and his friends were anxious to help him. The races into which $\mathrm{Zia}$ had been I 66 


\section{AND HER OFFSPRING}

put show that she was expected to do what little she could manage to accomplish early in the season; but it was not until the last day of September that she appeared, and then in a Two-Year Old Optional Selling Plate. She had no quotation and finished nowhere. Being fit and well, however, she was given another run for a similar Plate at the Second October Meeting. After these two exhibitions it is rather surprising to find her carrying $\delta$ st. I I lb. in the Downe Nursery at Liverpool, except, indeed, that none of the sixteen starters had less than $7 \mathrm{st} .4 \mathrm{lb}$. $\mathrm{Zia}$ did no more than she had done in her previous races, and coming out again for the Eglinton Nursery at Manchester, this time with 8 st., she did not attain to the mild distinction of having any price in the betting. As a three-year-old she made one appearance, in a handicap at the Newmarket Craven Meeting for animals of her age; she carried only 6 st. I I lb., and made no show. It is to be feared that she must be set down as of small use for racing purposes. Lord Sefton bought her, however, it being arranged that if he sold her it must be to Mr. Fairie for the sum he had received, 500 guineas. Lord Sefton would have paid thrice as much, a mare so bred being valuable for the stud, but Mr. Fairie declined to accept more. 


\section{GALICIA : HER FORBEARS}

In I9I I Galicia was sent to Mr. Leopold de Rothschild's Radium, who was standing at a fee of 200 guineas, which, indeed, his performances seemed fully to have justified. This son of Bend Or and Taia, a remarkably good-looking horse, had been fourth for Spearmint's Derby, behind Picton and the subsequent Leger winner, Troutbeck, but in front of Beppo, Gorgos who had won the Two Thousand for Mr. Arthur James, Black Arrow, Sancy, The White Knight winner of two Ascot Cups, Lally who started favourite for this Derby but failed through inability to stay, and amongst others Mr. Fairie's Plum Tree, who won him the Goodwood Cup later in the season. Radium did not run again as a three-year-old, but made exceptional improvement, as a fouryear-old he carried off the Newmarket Biennial by three lengths from Troutbeck-the Duke of Westminster's colt, however, giving a stone-and then afterwards was second for the Great Yorkshire Handicap, securing the Lowther Stakes, the Rutland Handicap with 9 st. Io lb.-giving the second, Impression, a colt of his own age, 3 st. $8 \mathrm{lb}$.- and the Jockey Club Cup, in which he beat The White Knight and that good stayer Torpoint. As a five-year-old Radium did still better. In the Coronation Cup The White Knight reversed the Jockey Club Cup form, as I68 


\section{AND HER OFFSPRING}

he did again in the Gold Cup, for which he beat Radium by a couple of lengths; but after Ascot Mr. Leopold de Rothschild's horse was out five times without defeat. He took the Dullingham Plate with ro st. $6 \mathrm{lb}$; the Goodwood Cup, 9 st. 2 lb., from Torpoint, 9 st. 7 lb., and The White Knight, Io st. ; the Doncaster Cup, The White Knight this time fourth at even weights. For the Beaufort Stakes at the Newmarket First October Meeting the horse walked over, and this year he had only one moderate opponent in the Jockey Club Cup.

Thus he went to the stud with excellent prospects, which may yet possibly be fulfilled. His son by Galicia was called Radames, a good-looking bay colt about whom up to the time of writing, however, there is little to be said. He came out for the New Stakes at Ascot, as his half-brothers had done; but roo to 7 was offered against him, and he "had nothing to do with the finish," in which Colonel Hall Walker's Let Fly beat Mr. A. F. Basset's Roseland (the latter giving $7 \mathrm{lb}$.) by a neck, the late Lord Cadogan's Redfern, a head behind, third. Radames, indeed, made no show. His only other appearance was in the July Stakes. Roseland, 9 to 2 on, beat $\mathrm{Mr}$. Neumann's Elkington, 7 to I, by half-a-dozen lengths, Radames, Io to I, another half-dozen

$$
\text { I69 I } 2
$$




\section{GALICIA : HER FORBEARS}

lengths away. This brings up the history of Galicia's offspring to the present time. For the season of I9I5 all going well the successes of the family may be continued by a bay colt called Kwang Su, by Cicero, specially prominent now as sire of the King's Friar Marcus. Kwang Su is considered highly promising. 


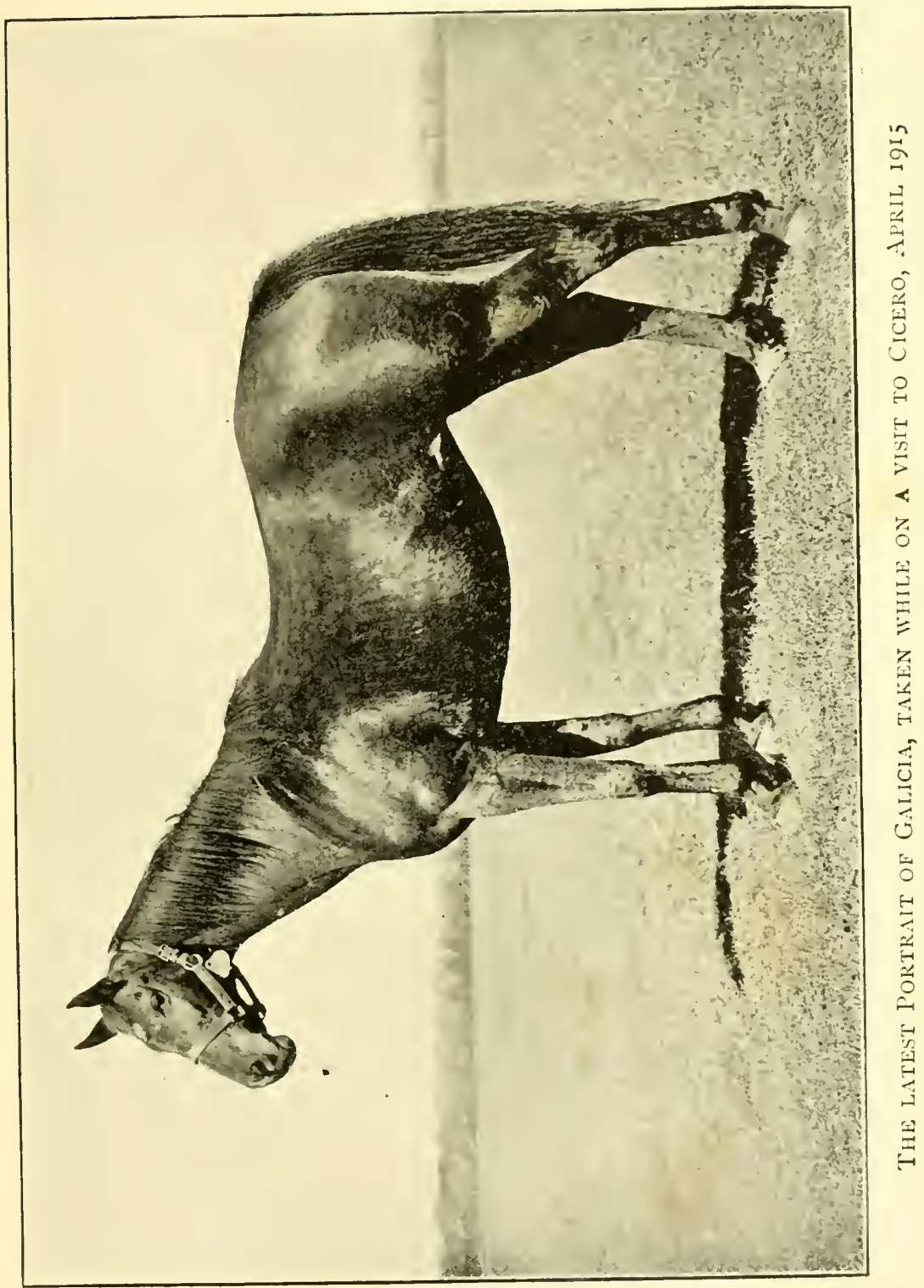





\section{AND HER OFFSPRING}

\section{CHAPTER VI}

\section{BAYARDO AT THE STUD}

IN I9I I Bayardo went to stand at the Manton House stud at a fee of 300 guineas, and as a matter of course his subscription list was speedily filled. Amongst owners who sent mares was His Majesty the King, Loch Doon being chosen for the horse, and the result, a bay colt called Border Don, was generally admired. I remember Richard Marsh telling me that the colt "looked like racing and showed all his sire's quality." Evidence of what is expected from a horse is furnished by the entries made for him, and Border Don was put into six-and-twenty races as a two-year-old. He did not thrive, however, and could not be brought out until late in the season, when he ran for the Great Sapling Plate at the Sandown Meeting in October. He was not expected to win, it being correctly supposed that the race lay between Lord Michelham's Plucky Liège and Lord Carnarvon's Volta, who finished first and second with a head between them ; Border Don figured in the betting, $S$ to I being taken. Mr. Fairie himself had very 


\section{GALICIA : HER FORBEARS}

few foals by his own horse. A filly named Ferrara, a daughter of Bona Dea, was afforded chances if she were good enough to take them, being engaged in the New Stakes, the Middle Park Plate, and other notable events; but she could not be produced.

The horse had only one winner in fact, fortunately one of some account, a filly called Good and Gay, her dam Popinjay, the property of Mr. Waldorf Astor. She came out for a newlynamed race at Ascot, the Bessborough Stakes, apparently not much fancied, for she started at Ioo to 8, there being a hot favourite in $\mathrm{Mr}$. J. B. Joel's Polystome, Good and Gay winning, however, though only by a head, from a black son of St. Frusquin and Menda called Rossendale belonging to Sir John Thursby. Good and Gay was almost favourite for the Chesterfield Stakes at the Newmarket Second July, in which she finished third to Colonel Hall Walker's Follow Up, but she took the Buckenham Stakes from the same owner's Sea Eagle, the favourite, the Duke of Westminster's Manxman, a colt who had shown good form, beaten four lengths for second place. Her fourth and last appearance was in the Bretby Stakes, in which she was beaten a couple of lengths by a really good filly of $\mathrm{Mr}$. Hulton's called Silver Tag. Good and Gay's 


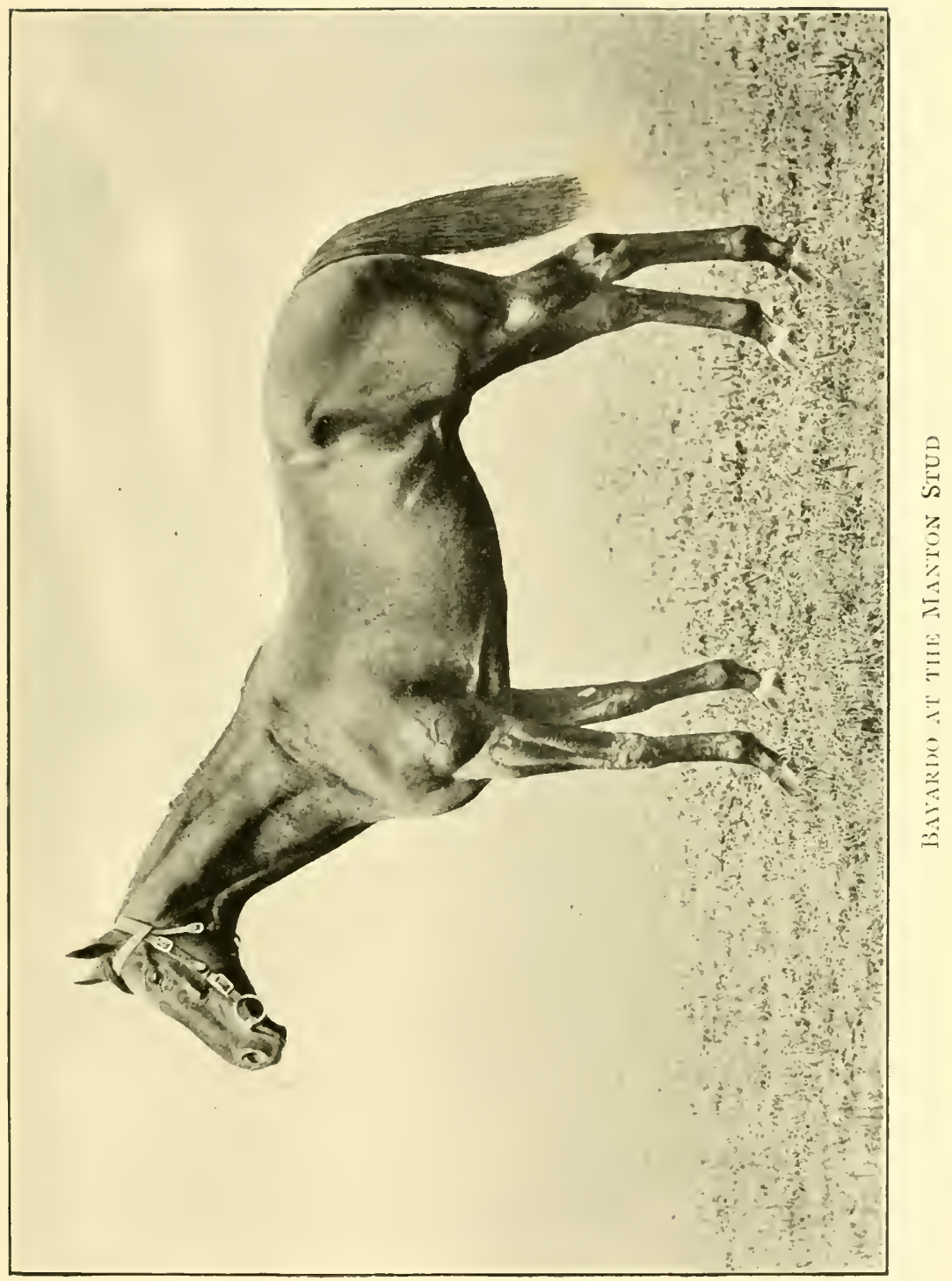





\section{AND HER OFFSPRING}

two races yielded $f_{36} 3^{2}$, so that Bayardo had a not altogether humble place in the list of winning sires.

Five of his yearlings were offered by auction in 1913. Bayardino, a son of Lady Raeburn, made 810 guineas, a son of The Broom $45^{\circ}$ guineas, another son of Royal Marriage I 500 guineas, one of Alicia 3700 guineas, bought by Lord Lonsdale, and one of Cheshire Cat 3 Ioo guineas. In IgI4 were sold three colts and a filly. Sir William Cooke gave 3000 guineas for a son of Dame d'Or, Captain J. G. R. Homfray I 000 guineas and Mr. H. M. Hartigan 700 guineas respectively for sons of Elizabeth $M$. and Evadne, and at the Second October Meeting the filly, a daughter of Star of the Sea, was purchased by Sir Thomas Dewar for 870 guineas.

In the spring of I9I5 two young Bayardos came out at Newbury, a three-year-old named Wordsworth, dam Rydal Mount, who had not run the previous season, and a two-year-old, Ali Bey, dam Mowsali. The race in which the former took part was the Greenham Stakes for three-year-olds, and some of the best of the age opposed him, all, however, it should be noted, giving him weight. He carried 8 st. $5 \mathrm{lb}$. Colonel Hall Walker's Let Fly (9 st. 4 1b.) and 


\section{GALICIA : HER FORBEARS}

Lord Carnarvon's Volta (9 st. I lb.) were equal favourites at I I to 4, odds of 8 to I laid against Wordsworth, and, Volta being unable to stay, the race ended in a dead-heat between Let Fly and Mr. J. B. Joel's Sunfire (9 st. 4 lb.). At Chester the son of Rydal Mount was backed at 5 to 4 for the Eaton Maiden Plate and beaten a length by St. Ronald, making his first appearance. Ali Bey was one of twentyeight starters for the Beckhampton Stakes, which came immediately after the Greenham. This two-year-old race has almost always been won by the favourite, notwithstanding that the field is invariably large: as many as thirtyeight have run. Precedent was followed. Duggie won at 5 to 2, Ali Bey fourth. At Chester the son of Bayardo took the Mostyn Stakes, 4 to I on him, from two poor animals; but next day, though beaten in the Ormonde Stakes, showed really good form. He finished second to Lord Derby's smart Marchetta filly, giving her Io $\mathrm{lb}$., that is $7 \mathrm{lb}$. more than weight for sex, in front of winners, Louviers d'Or and Dalnacardoch. Ali Bey was beaten half a length, and according to his jockey ought to have won. His failure was attributed to an unusual reason. Some newspapers were being blown about in a high wind; they baulked the 


\section{AND HER OFFSPRING}

colt as he rounded the last turn and threw him out of his stride. He should certainly win races.

Sir William Cooke's Dame d'Or colt was also distinctly unfortunate to be beaten in the first race he ran, the Spring Stakes at the Newmarket Second Spring Meeting. He started at I I to Io, and in more expert hands could hardly have lost. Donoghue on Captain Dermot $\mathrm{M}$ 'Calmont's Roi d'Ecosse outrode the jockey on the favourite and won by a short head. Up to the time of writing the Dame d'Or colt has been out once more, and that successfully. He appeared at Windsor on the 22nd May, a memorable date, for on it was held the final meeting prior to a cessation of sport decried by the Government in consequence of the great war. For this Speedy Two-Year-Old Plate ten ran, and it was considered by most men, including Sir William, present in the khaki which at this period was so conspicuous on all courses, to be a good thing. At one time odds of nearly 2 to 1 were laid on the colt, but it became known that Lord Carnarvon's Sarrasin was much fancied, and the young Bayardo behaved very badly at the post, refusing to join his horses, so that his market position was affected, it being feared that he might be left. He started at 13 to $S$ on, 


\section{GALICIA}

2 to I against Sarrasin; but though the Dame d'Or colt was not off first he speedily took his place and won from Mr. Frank Curzon's Lady Binns, Sarrasin third. I wind up my book on the evening of this Windsor Meeting. 


\section{THE PEDIGREE OF BAYARDO}

\begin{tabular}{|c|c|c|c|c|c|}
\hline & & & & $\begin{array}{l}\text { Newminster } \\
\text { (B. } x 8,8) \text {. }\end{array}$ & $\begin{array}{l}\text { Touchstone. } \\
\text { Beeswing. }\end{array}$ \\
\hline & & & (B. 1860). & The Slave & Melbourne. \\
\hline & & 몸 & & (B. $\left.185^{2}\right)$. & Volley. \\
\hline & $\dot{\vec{m}}$ & $\stackrel{\text { İ }}{=}$ & & $\begin{array}{l}\text { Kettledrum } \\
\text { (Ch. I858). }\end{array}$ & Rataplan. \\
\hline & $\infty$ & & $\begin{array}{l}\text { Lady Langden } \\
\text { (Br. } 1868 \text { ) }\end{array}$ & & \\
\hline & $\dot{\underline{\Sigma}}$ & & & $\begin{array}{l}\text { Haricot } \\
(\mathrm{Br}\end{array}$ & Lanercost. \\
\hline & $\begin{array}{l}\vec{L} \\
z \\
0 \\
\alpha\end{array}$ & & & $\begin{array}{l}\text { Galopin } \\
\text { (B. I872). }\end{array}$ & $\begin{array}{l}\text { Vedette. } \\
\text { Flying Duchess. }\end{array}$ \\
\hline & $\stackrel{2}{0}$ & & (Br. I 88o). & Mavis & Marconi. \\
\hline$\dot{8}$ & & 与ुํㅇㅇ & & (Ch. I874). & Merlette. \\
\hline ले & & हैं & & $\begin{array}{l}\text { Sterling } \\
\text { (B, } 868)\end{array}$ & Oxford. \\
\hline$\vec{z}$ & & & Black Corrie & & Whisper. \\
\hline 胥 & & & & $\begin{array}{l}\text { Dau. of } \\
\text { (B. 186I). }\end{array}$ & $\begin{array}{l}\text { Wild Dayrell. } \\
\text { Lady Lurewell. }\end{array}$ \\
\hline$\frac{\frac{0}{0}}{j}$ & & & Vedette & $\begin{array}{l}\text { Voltigeur } \\
\qquad(\mathrm{Br} .18+7) .\end{array}$ & $\begin{array}{l}\text { Voltaire. } \\
\text { Martha Lynn. }\end{array}$ \\
\hline$\frac{\ddot{9}}{\circ}$ & & $=\dot{a}$ & (Br. 1854). & $\begin{array}{l}\text { Mrs. Ridgway } \\
\text { (B. 1849): }\end{array}$ & $\begin{array}{l}\text { Birdcatcher. } \\
\text { Nan Darrell. }\end{array}$ \\
\hline 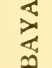 & & రొ & & Flying Dutchman & Bay Middleton. \\
\hline & $\infty$ & & Flying Duchess & & Barbelle. \\
\hline & $\dot{2}$ & & (B. 1853$)$. & $\begin{array}{l}\text { Merope } \\
\quad(\text { B. I84I). }\end{array}$ & $\begin{array}{l}\text { Voltaire. } \\
\text { Velocipede's dam }\end{array}$ \\
\hline & $\stackrel{\varrho}{\sigma}$ & & & Sterling & Oxford. \\
\hline & 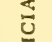 & & Isonomy & & Whisper. \\
\hline & 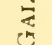 & $\dot{\vec{a}}$ & (B. 1875). & Isola Bella & Stockwell. \\
\hline & & & & & Isoline. \\
\hline & & & & Muncaster & Doncaster. \\
\hline & & $\stackrel{g}{2}$ & Lady Mluncaster & & Winder mere. \\
\hline & & & (Ch, I884). & $\begin{array}{l}\text { Blue Light } \\
\text { (Ch. 1870). }\end{array}$ & Rataplan. \\
\hline & & & & & \\
\hline
\end{tabular}




\section{THE PEDIGREE OF LEMBERG}

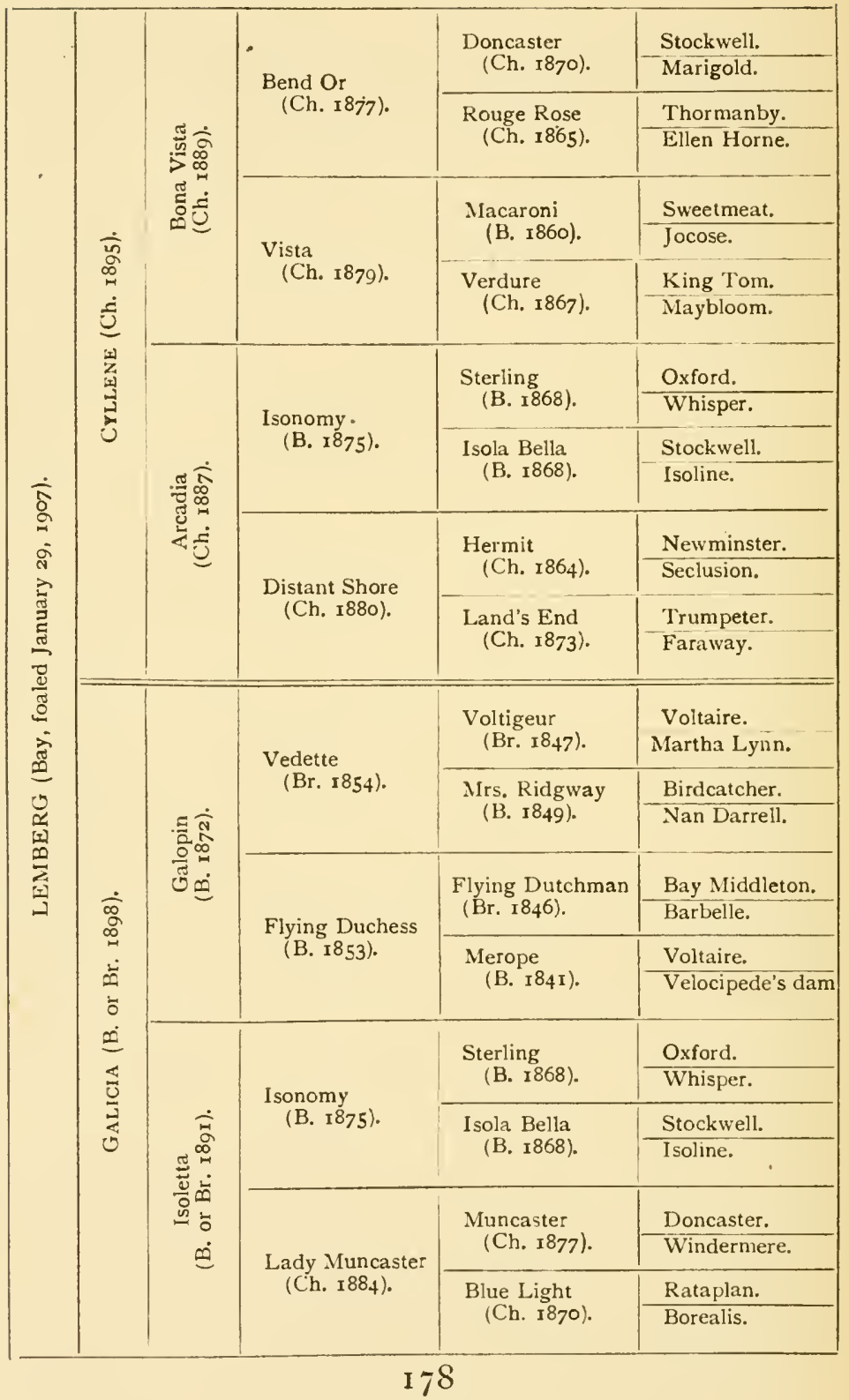


PRINTED IN GREAT BRITAIN BY BALLANTYNE, HANSON \& CO. LTD. EDINBURGH AND LONDON 


A. ALLEN \& CO. Specialists In

3. A. ALLEN \& CO.
Books on LONOON, S.W.I

The Horse 


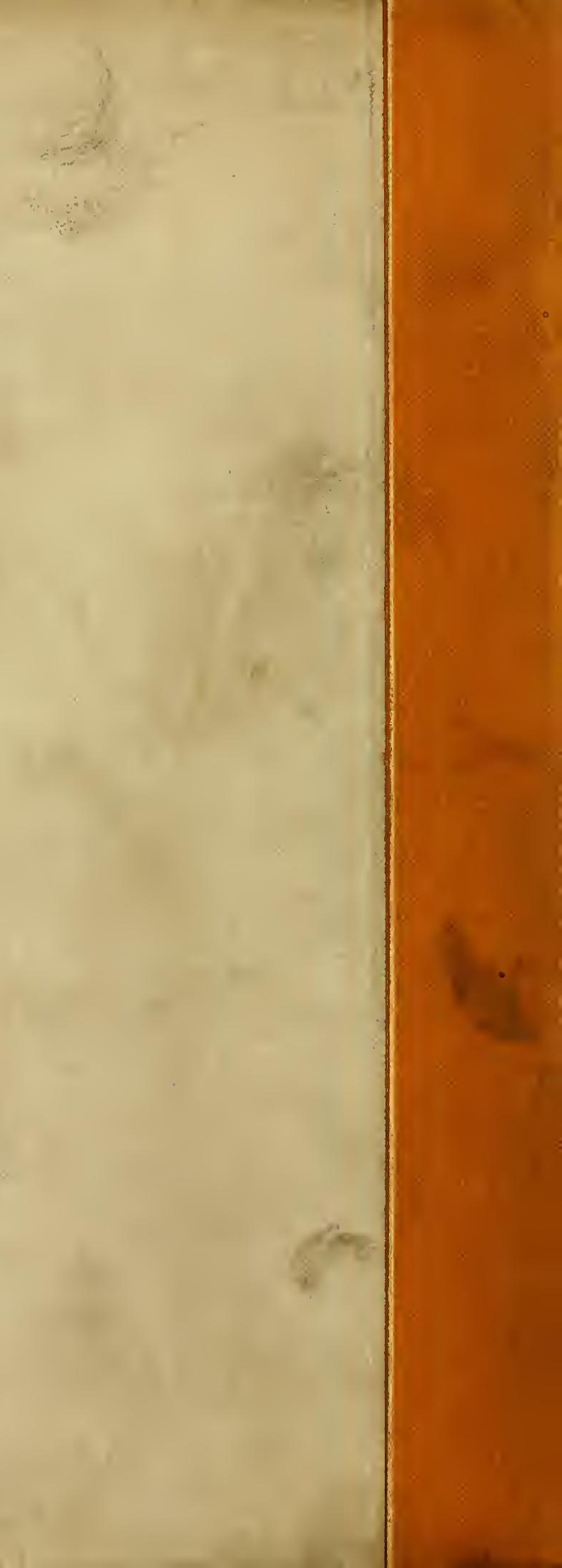

